\title{
Trombin activity in plasma : a study on its formation and inhibition
}

Citation for published version (APA):

Xi, M. (1988). Trombin activity in plasma : a study on its formation and inhibition. [Doctoral Thesis, Maastricht University]. Rijksuniversiteit Limburg. https://doi.org/10.26481/dis.19880701mx

Document status and date:

Published: 01/01/1988

DOI:

10.26481/dis.19880701mx

Document Version:

Publisher's PDF, also known as Version of record

\section{Please check the document version of this publication:}

- A submitted manuscript is the version of the article upon submission and before peer-review. There can be important differences between the submitted version and the official published version of record.

People interested in the research are advised to contact the author for the final version of the publication, or visit the DOI to the publisher's website.

- The final author version and the galley proof are versions of the publication after peer review.

- The final published version features the final layout of the paper including the volume, issue and page numbers.

Link to publication

\footnotetext{
General rights rights.

- You may freely distribute the URL identifying the publication in the public portal. please follow below link for the End User Agreement:

www.umlib.nl/taverne-license

Take down policy

If you believe that this document breaches copyright please contact us at:

repository@maastrichtuniversity.nl

providing details and we will investigate your claim.
}

Copyright and moral rights for the publications made accessible in the public portal are retained by the authors and/or other copyright owners and it is a condition of accessing publications that users recognise and abide by the legal requirements associated with these

- Users may download and print one copy of any publication from the public portal for the purpose of private study or research.

- You may not further distribute the material or use it for any profit-making activity or commercial gain

If the publication is distributed under the terms of Article $25 \mathrm{fa}$ of the Dutch Copyright Act, indicated by the "Taverne" license above, 


\section{Trombin activity in plasma}

A study on its forwation and inhibition

\section{Proefschrift}

ter verkrijging van de graad van doctor

an de Rijksunfversiteit Limburg te Mastricht

op gezag van de Rector Magalficus, Prof. Dr. F.I.M. Bonke,

rolgens het beslult van het College van Dekanen,

in het openbsar te verdedigen

op vrijdag 1 full 1988 om 16.00 uur

door

MA XI

geboren te X1an (China) 1955 
Promotor : Prof. Dr. H.C. Hemer
Co-promotor : Dr. M.C.B. van Dan-Mieras

Beoordellagsconinisie: Prof. Dr. M. Alach

Prof. Dr. G.A. Blithar

Prof. Dr. C.P.A. van Boven

Prof. Dr. P.J. Brombacher

Prof. Dr. C. Sorla

The experituents in this thesis have been carried out in the Departaent of Blochemiatry (Prof, Dr. H.C. Hewker, University of Limburg, Maasricht, The Netherlanda) under the supervisor of Dr. S. Beguin and Dr. T. Lindhout.

The work presented In this thesis was supported in part by virus Cancer Prevention Assoclation, France (President. Prof. Dr. Guy de The).

The Netherlands Heart Foundation contributed to the printing costs of this thes 1s. 
CONTENTS

Page

Chapter I INTRODUCrION

Chapter II THB IMPORTANCE OR FACTOR IX ACTIVATION

IN THROMBOPLASTIN-DEPBADENT COAGULATION

(THB JOSSO PATHWAY) IN PLASMA

Chapter III THE RELATIVB IMPORTANCE OF VARIOUS VITAMTM R-DEPENDENT CLOTTING PACTORS ON THE PROTHROMBINASB ACTIVITT IN PLASMA OF ORALLY ANTICOAGULATED PATIENTS

Chapter IV SJAMP, A HEPARIN-LIKE MATERIAL PROM STICHOPUS JAPONICUS SELENRA: BFFECT ON THB GENERATION OF THROMBIN ACTIVITT IN PLATELET POOR AND PLATELET RICR PLASMA

Chapter $v$ SJAMP, A HEPARIN-LIRB MATERIAL PROM STICHOPUS JAPONICUS SELENKA: COPACTOR DEPENDENCT OR ITS INHIBITORI EPFBCT ON THROMBIH ACTIVITT IN PLASMA

一般性讨论

SUMAART 

CEAPTER I

INTRODUCTION

Hemostasis is a physiological process that enables the organism to protect itself against the loss of blood when infury occurs. The components that contribute to the hemostatic process involve the vessel wall, the blood platelet and other blood cells and humoral factors most of them pro-serine proteases present in the blood. Because of great advances in the field of blochemical technlques, the (pro-)serine proteases of the coagulation mechamism could be extensively studied over the past 20 years. The coagulation pathway originally thought to be a "cascade"" sequence (see below) turned out to be more complex than originally supposed and several new elements and interrelationship between the cascade reactions have been added to the scheme. In this introducling chapter a short review on the present knowledge of blood coagulation and anticoagulant mechanism 18 given.

THE MTCCHANISY OR COAGULATION

During the process of coagulation serles of Inactive serine protease zymogens 18 transformed into active enzymes by limited proteolysis. Durling this "cascade" process the f1rst enzyme that 1 s activated, activates a second, and this again activates a third enzyme etc. etc. and in this way a biochemical amplification of the process is obtalned $(1,2)$. The coagulation cascade eventually leads to the generation of a burst of thrombin, which is a blalogically very active proteln and the central enzyme of hemostasis. It acts on the vessel wall, it activates platelets and it 
catalyzes the conversion of fibrinogen into fibrin and so stimulates the formation of atable, flbria-relnforced platelet plug. It also activateg the coagulation factors and VII which are cofactors in the coagulation reactions, and factor XIII, the transglutaminase involved in the cross polymerlation reaction of the fibrin meshwork. BY 1 ts action on platelets, on factor $V$ and on factor VIII 1 excerts an important positive feedback action on 1 ts own formation. The thrombin activitles mentioned so far all have procoagulant character. When, however, thrombin 1 s bound to thrombomodulln, proteln present on the endothellal cell surface, the pracoagulant activities are Inhiblted and flbrimolytic activities are inltiated. Thrombomodulin-bound thrombin activates proteln $C$, which in turn inactivates the coagulation cofactors $V_{a}$ and VIII and stimulates fibrinolyois by reducting the inhibltion of plasminogen activator $(3,4)$. Finally, thrombin acts as a chemoatractant for Inflamatory cells and has a mitogenic effect on fibroblasts (5).

In figure 1 a simplified acheme of blood coagulation is givem. It can be een In this figure that blood coagulation can be triggered via two distinct pathwaya, the so-called intrinsic and extrinsic pathways of coagulation and that there 1 s cross reaction between these pathways, the "Josso loop".

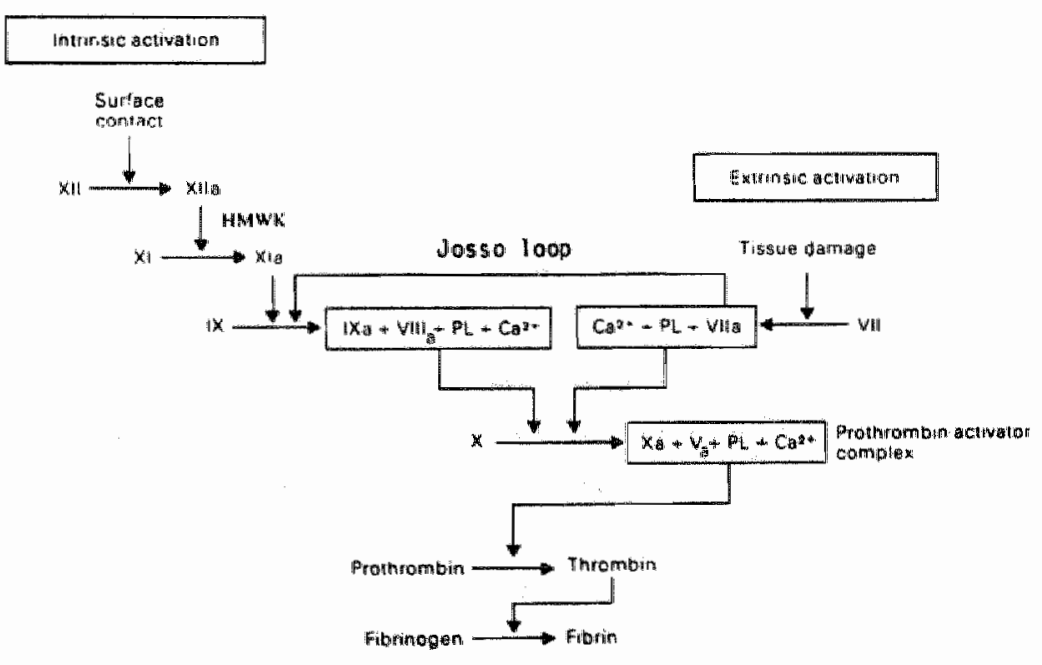

Fig. 1. Schematic representation of the coagulation pathways in plasma. 
The intrinsic pathway

The Intrinsic pathway of coagulation 1 s tr1ggered when blood comes into contact wth negatively charged surfaces. This contact results in the

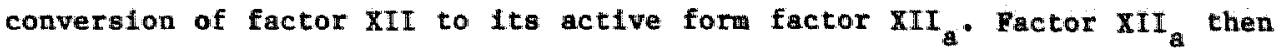
catalyzes the activation of prekallikrein to kallikrein and kallikrein in turn accelerates the activation of factor XII. So, contact with megatively charged surfaces establishes a reciprocal actlvation of factor XII and kallikrein (6-9). For an optimal activation of factor XII three factors are needed, 1.e. prekallikrein, a negatively charged surface and high molecular weight kininogen (HMWK). The role of BMWR 1 is to link the prekallikrein to the surface. Therefore, it functions as a non-enzymatic cofactor in the contact activation reactions. It has been proposed that activation of factor XII is associated with the formation of several active fragments (10). While one of these fragments has the primary function of activating the kallikrein-kinin system, another fragment initiates the intrinsic pathway of coagulation, which induces the activation of factor XI. Moreover, the contact activation system also inftiates the fibrinolytic system and the complement system.

The activation of factor $X I$ requires the presence of HMWK, which wedlates the binding of both prekallikrein and factor XI to the surface, where both factors are actiwated by factor XII. The factors XII, XI, prekallikrein and HMWR are nomally grouped together and are Indicated as the contact activation factors.

The activation of factor $\mathrm{IX}$ by factor $\mathrm{XI}_{\mathrm{a}}$ only requires the presence of $\mathrm{Ca}^{2+}$-1ons. However, factor $\mathrm{VII}_{\mathrm{a}}$ in the presence of tissue thromboplastin can also activate factor IX and therefore factor IX 1 is considered to be a polnt of linkage between the lntrinsic and extrinsic pathways (see the paragraph on extrinsic activation for detalls). Factor $I X_{a}$ together with phospholipids, $\mathrm{Ca}^{2+}-10 \mathrm{~s}$ and factor VIII, forms a factor $x$ activating complex, the so called tenase complex (11). Factor Ix blnds to a negat $1-$ vely charged phospholipid surfaces via $\mathrm{Ca}^{2+}$-bridges. In the tenase complex the non-enzymatic cofactor, factor VIII, substantilily accelerates the activation of factor $x$ to factor $x_{a}(12)$. Factor $X$ can also be activated via the extrinsic activation pathway (gee below) and therefore in the originally proposed coagulation scheme factor $x$ is the polnt of linkage between the intrinsic and the extrinsic pathways. 
Activated factor $x$ catalyzes the conversion of prothrombin to thrombin and again this activation takes place in a multimerlc complex. Factor $x_{a}$ " together wth phospholiplds, $\mathrm{Ca}^{2+}-10 \mathrm{~ns}$ and factor $\mathrm{V}_{\mathrm{a}}$ forms the so-called prothrombinase complex which is the site of activation of prothrombin to thrombln. Like factor $I X_{a}$ in the tenase complex factor $X_{a}$ binds to negatively charged phosphollpid surfaces via $\mathrm{Ca}^{2+}$-brldges and thls time factor $v_{a} 18$ the non-enzymatic cofactor, that substantially accelerates to activation of prothrombin $(13-15)$. Recent studies have shown that factor $x_{a}$ can also bind to positively charged phospholipld surfaces in a ca ${ }^{2+}{ }_{-}$ Independent way (16). Apparently, also on positively charged surface the conversion rate of prothrombin can be lncreaged. The physiological significance of this phemomenon is as get unknown.

Thrombin, the flnal product of the coagulation cascade, amplifles its own formation via the activation of the non-enzymatic cofactors $v$ and VIII. It also stimulates the so-called platelet "flip-flop" which leads to the exposure of procoagulant phosphollplds om the platelet surface. This procoagulant surface again supports the coagulation cascade reactions (17-19). Finally, thrombin catalyzes the conversion of fibrinogen to fibrin and activates factor XIII. It thus causes the formation of a stable, covalently linked network of fibrin. Thrombin, by its action on both platelets and fibrin thus 18 the central enzyme in the formation of a stable fibrin reinforced platelet plug.

The extrinste pathway and the Josso $100 \mathrm{p}$

The extrinslc pathway is initiated when blood is exposed to tissue thromboplastin that 18 released from damaged tssue. Tisue thromboplastin 10 a ILpoprotein to which unactivated factor VII can bind. This complex then ha some proteolytic activity. It can activate factor $X$ and activated factor $X$ in tura can "retroactivate" factor VII and in this way the very active thromboplastin-factor VII complex results. In this complex the roles of phosphollpld surface and non-enzymatic cofactor are played by the $11 \mathrm{pld}$ and the protein part of tiasue factor (20-22). The activation of prothrombin then proceeds in the way described in the preceding paragraph.

The factor VII -phosphollpid complex is also involved in the activation of factor IX, and thus in the tuteraction between the intrinsic and ex- 
trinsic pathways of coagulation (23-25). Recent studies indicate that this activation reaction wight constitute a very important triggering mechanism in coagulation (26-33). However, kinetic in vitro studles have shown that the rate of factor $X$ activation via a factor VII -thromboplastia dependent activation of factor $I X$ is much smaller than that of a direct activation of factor $X$ via the factor VII a-thromboplastin complex. Therefore, it has hardly been accepted that the factor VII -thromboplastin dependent actiwation of factor IX has any Importance in vivo.

However, some congenttal coagulation disorders can not be explained properly by a defect in elther the Intrinsic or the extrinsic pathway. For example, why are, In haemophlliac patients, the deflctencles in the intrinsic activation pathway not compensated by the intact extrinsic pathway? Why do deficiencles of the contact factors not produce severe disturbances of the hemostatic process? In chapter II of this thesis, a study on the importance of factor IX activation in thromboplastin-dependent coagulation (the Josso Pathway) In plagma la presented.

\section{NATURAL INHIBITORS}

The activation of the coagulation cascade is controlled by number of regulatory mechanism, some of which entall plasma protelns that can neutralize or Inactivate certain groups of activated coagulation factors at various sites. Such plasma protelns (1mhibltors) include antithrombin III and heparin cofactor II, $\alpha_{2}$-macroglobulin, $\alpha_{1}$-antitrypsin, and cl inhibitor. These proteins are gerine protease inhlbitor ("gerplns") that attack activated clotting enzymes. A quite different type of inhlbition is excerted by activated protein $C$ that 1 tself being a protease, attacks the protein co-factors (Factor $v_{a}$ and VIII $_{a}$ ) of the activation complexem. Antithrombin III and protein $C$ (w1th 1 ts cofactor protein s) seem to be the most Important inhibitors, although the relative importance of other serpins for each different activated factor btill remalins a question of active research. The recently described vascular anticoagulant proteln which interferes with the interaction of the clotting factors with a procoagulant surface provides an additional anticoagulant mechanism ( 34 ). In figure 2 the site of attack of natural inhibitors in plasma 18 given. 


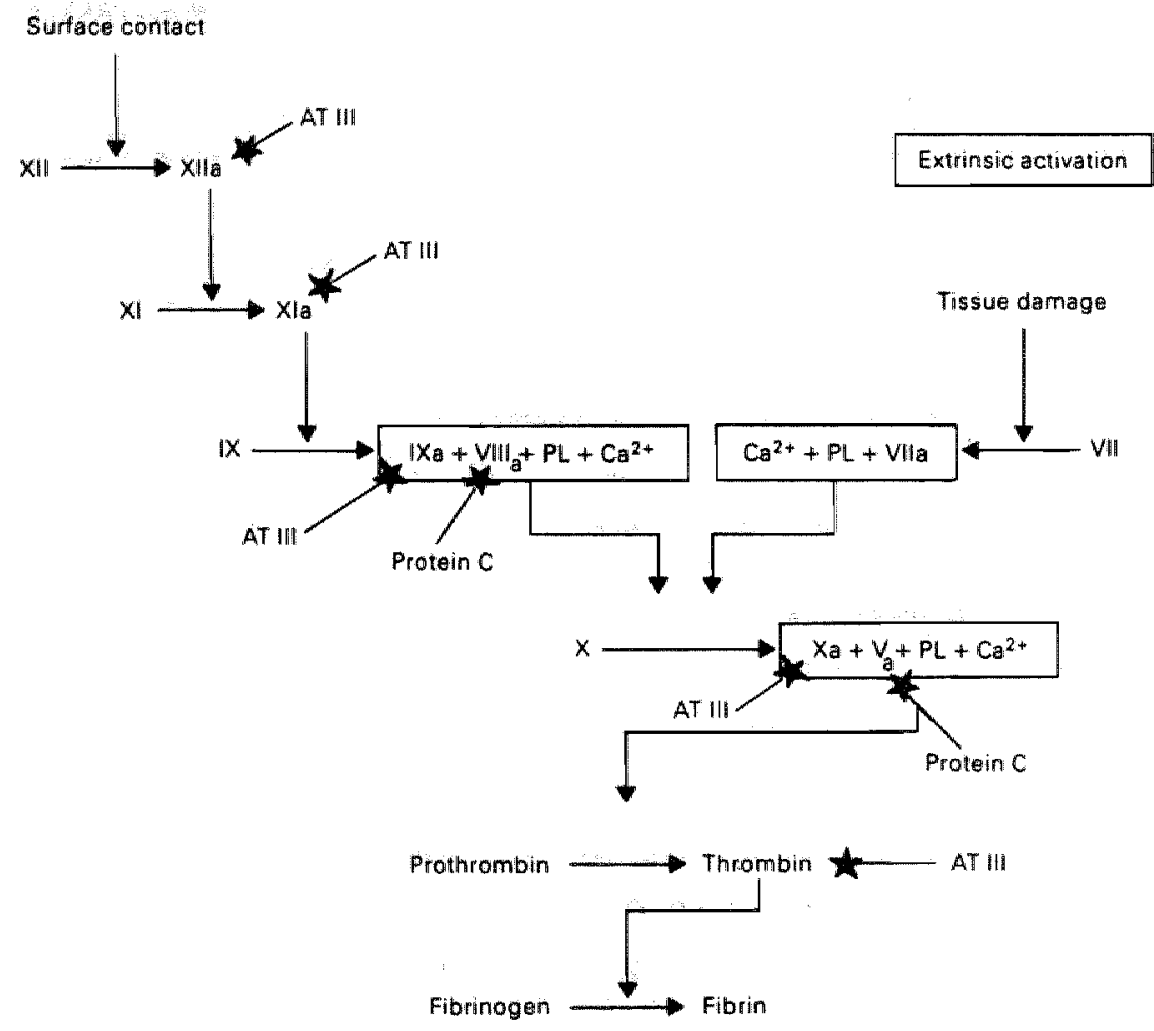

F1g. 2. S1tes of attack of natural Inhibitors in plasma. 
Ant1thrombin

Antithrombin III (AT-III) neutrallzes wost of the gerine proteases of the coagulation casicade by forming covalent $1: 1$ molar complexes (35-40). Within the wide spectrum of neutralizing actions of AT-III, the inhibition of thrombin and factor $x_{a}$ is considered to be the predominant anticoagulant mechanism. The importance of factor $x_{a}$ Inhibltion by AT-III has been questloned, however $(41)$. Complex formation between AT-III and coagulation factors normally proceeds slowly but is markedly accelerated by heparin. Th1s constitutes one of the most important effects of heparin administered for anticoagulant therapy.

In addition to the anticoagulant activity of AT-III a smal1 part of antithrombin activity in plasma 18 accounted for by the heparin cofactor II (HC-II) (42-44). Inlike AT-III, BC-II has a narrow speciflcity and only neutralizes thrombin. Complex formation between HC-II and thrombin can be accelerated not only by heparin but also by dermatan-sulfate $(45,46)$. Although it has been reported that the hereditary deficlency of HC-II is assoclated with thrombosis, the relevance of HC-II deflclency as a risk factor for the development of thrombosis is st111 matter of discussion (47).

\section{Protein C}

Protein C is a vitamin k-dependent protein which possesses a selective anticoagulant activity in the coagulation cascade. The cilnical findings that a hereditary deficlency of proteln $C$ can lead to repeated thronbotic episodes and the effects observed during acquirad deflelencles such as liver disease and during the starting phase of oral antlcoagulant therapy suggest that protein C plays an important role in phys1ological hemostasis $(48-52)$.

Protein $C$ is activated in vivo at the vessel wall by a complex of thrombin and thrombomodulin (51). Activated protelm c selectively destroys factor VIII $a$ and factor $V_{a}$ in the presence of another vitamin $K$-dependent protein, protein $S$, and thus serves to $11 \mathrm{mit}$ propagation and generation of thrombin (52). It has been shown that actlvated proteln $\mathbb{C}$ also sitimulates the fibrinolytic system through reducing the inhibition of plasminogen 
activator (4). Therefore, a reduction of proteln $c$ in plasma w11 result not only in disturbed regulation of the thrombin formation but also in delayed activation of the flbrinolytic system. It is possible that the combination of these two blologlc effects 13 responsible for the lacreased thrombotic tendency lin congenttal deflciency.

\section{ANTICOAGULANTS}

\section{oral antelcoagulants}

Prothrombin, the factors VII, IX, $X$ and the anticoagulant protelns $C$ and $\mathrm{s}$ belong to the vitamin $\mathrm{K}$-dependent protelas. The common characteristic of these proteins is the presence of $\mathcal{V}$-carboxylated glutamic acid residues in the N-terminal region of the protein chain (53). Vitamin $k$ is esiential for the carboxylation of certain glutamic acid residues in these protelns in a posttranslational step during hepatic synthesis $(54,55)$. The V-carboxylated coagulation factors can bind to negatively charged phospho1.pld surfaces via $\mathrm{Ca}^{2+}$-bridges. Thls Interaction greatly enhances the efflciency of their participation in the coagulation cascade reactions.

Vitamin $K$-antagonists such as the coumarin congeners interfere with the carboxylation of the vitamin $k$-dependent coagulation factors, which results In the synthests of blologically inactive but tmonologtcally detectable forms $(56,57)$. These luactive forms, called PIVKA (58), reach the blood stream but are unable to bind to negatively charged phospholipids via $\mathrm{Ca}^{2+}$-brIdge $(59,60)$. Therefore, the formation and activity of at least three procoagulant complexes, 1.e. the factor $X$ converting complexes $\left(\right.$ IX $_{a}-$ VIII $_{a}$-phospholipld and VII $_{(a)}$-Thromboplastin) and the prothrombin converting complex (prothromblnase), will be linfluenced by oral anticoagulant therapy with vitamin $K$ antagonists. Th1s will, of course, result In a decrease in thrombln generation.

Due to the different half-11fe times of prothrombin, factor VII, factor IX and factor $x$, the anticoagulant effect gradually reaches 1 ts steady level after infliation of vitamin $K$ antagonist therapy. Treatment with vitamin $R$ antagonist first brings about a reduction of the factor VII activity, later also the effective activity of the factors IX, $x$ and pro- 
thrombin decrease (61). For a deep and stable antlcoagulant effect the levels of the $v i t a m i n ~ R$-dependent clotting factors are normally regulated down to about $20 \%$ of normal (61). This level of clotting activity is considered as an effective antlcoagulant treatment. However, this estimation of the potential clotting activity is based on the overall clotting test, 1.e. prothrombin time. The relative contributions of the individual clotting factors to this hypocoagulability of plasma are not clearly understood. In chapter III of this thes18, a study of the relative importance of varlous vitamin $\mathrm{K}$-dependent clotting factors on prothrombinase activity in dilcoumarol plasma is presented.

\section{Hepar1n}

Heparin is a mucopolysaccharlde. It is composed of a monosaccharide chain of varlable length containing L-glucourlonic acid, L-Iduronic actd and D-glucosamine. The Iduronic acid and glucosamine are partly sulfated, the latter in addition showing partial acetylation (62). In commercial heparin, the anticoagulant activity is present in fractions with malecular welght between $4,000-40,000$ daltons and over 20 molecular specles differing in charge can be identifled in a single preparation by electrophoretic analysis (63). These distinct molecular species are all called heparin because they share a measurable net anticoagulant activity defined by specific in vitro assays. However, they may differ from each other in a varlety of other blologic activities, as well as in the mechanism by which they act to prevent thrombosis.

The action of heparin in plasma is to accelerate the formation of complexes between active proteases and antithrombins (antithrombin III and heparin cofactor II). However, the administration of heparin for the treatment of a variety of acute thrombotic disorders is not always efficient, and the dose of heparin that can be administered is limited by the bleading risk. Moreover, some patients develop thrombocytopenia and thrombotic complications in association with heparln therapy. These clinical findings greatly stimulated the interest in compounds related to heparin which are reported to possess greater antithrombotic effectiveness while producing less bleeding than commerclal heparin. Studies on low molecular weight derivatives of commerclal heparin, on heparinolds, which are naturally 
occuring wcopolysaccharldes chemically distinct from heparin, and on synthetlc ollgosaccharlde sequences have recelved lncreasing attention in recent years $(64-69)$.

Stlchopus Japontcus actdic mucopolysaccharide (SJAMP) is a heparin-1ike compound that can be Isolated from the sea cucumber, stichopus japonicus selienka. Structure analys s shows that 1t contains 1-acetylgalactosame, glucouronlc ac1d, fucose and sulphate in the approximate ratio of $1: 1: 1: 4$, respectively (70). The wolecular welght of SJAMP is about $30,000-50,000$ daltons. Some physlcal properties of SJAM, like for instance the metachromatte intensity and the electrophoretic behaviour, are similar to those of heparin (70). The action of SJAMP with respect to 1 ts anticoagulant activity is not clear, although some studies report that SJAMP acts as an antlcoagulant by inhibltion of thrombln and that the mode of action of SJAMP 18 dIfferent from that of heparin (71). In chapter IV of this thesis, a atudy of effect of SJAMP on the generation of thrombin activity in both platelet poor plasma and platelet rich plasma is presented, and a study of the cofactor dependency of the Inhibition of thrombin activity by SJAM is final1y presented in chapter $v$ of this thesis.

\section{THE AIM OP THIS THESIS}

There is a tendency for modern coagulation biochemistry to become so sophisticated that the medical relevance of the findings is no longer tumedlately obvious to the medical doctors. It has been the alm of the author belng medical doctor, planning to work in medical surroundings for the rest of his career, to try and establish links between blochemlstry and the practice of medicine. Thus, the medical question Involved in the first experimental chapter is essentlally" "Why do hemophlllacs bleed" In the second experimental chapter we try to establish what clotting factor is essentla1 for the efficacy of oral antlcosgulant therapy. The rest of the work 1 s devoted to the elucldation of the mode of action of a traditional chinese antithrombotic medicine. 


\section{REFERENCES}

1. MacFarlane, R.G. (1964) Nature (London). 202, 498-499

2. Davie, E.W., Ratnoff, O.D. (1964) Sclence. 145, 1310-1312

3. Marlar, R.A., Klelss, A.J., Griffin, J.H. (1981) Ann. Acad. Sc1. 370, 303-310

4. Comp. P.C., Esmon, Ch.T. (1981) J. Clin. Inveat. 68, 1221-1228

5. Bar-Shavit, R., Wilner, G.D. (1987) Int. Rev. Exp. Path. 29, 213-24l

6. Griff1n, J.H. (1978) Proc. Nat1. Acad. Sic1. USA. 17, 1988-2002

7. Bouma, B.N., Griffin, J.H. (1986) Im: Blood Coagulation (Zwaal, R.F.A. and Hiemker H.C., ed1tors), 103-128, Blsevler, Amsterdam

8. S1lverberg, M., Kaplan, A.P. (1982) Blood. 60, 64-70

9. Tankersiley, D.L. , Finlayson, J.S. (1984) Blochemistry. 23, 273-299

10. Hitt, T. (1986) In: Biochemistry of Blood Coagulation and Fibrinolysis (W1tt, T. editor), 3-20, Boehringer Mannhe1m GmbH., West Germany

11. Hemker, H.C., Kahn, M.J.P. (1967) Nature (London). 215, 1201-1202

12. van Diefjen, G., Tans, G., Rosing, J., Hemker, H.C. (1981) J. Blol. Chem. 256, 3433-3442

13. Hemker, H.C., Esnouf, M.P., Hemker, P.W., Swart, A.C.M., MacFarlane, R.G. (1967) Nature (London). 215, 248-251

14. Rosing, J., Tans, G., Govers-Rlemslag, J.W.P., Zwaal, R.F.A., Hemker H.C. (1980) J. Blol. Chem. 255, 274-283

15. Lindhout, T., Govers-R1emslag, J.W.P., van de Wart, P., Hemker, H.C., Rosing, J. (1982) B1ochemigtry. 21, 5494-5502

16. Rosing, J. (1988) Personal Coumunlcation

17. Greengard, J.S., Walsh, P.N., Griffla, J.H. (1981) Blood. 58, 194

18. Bevers, B.M., Comfurlus, P., van R1jn, J.L.M.L., Hemker, H.C., Zwal, R.F.A. (1982) Eur. J. Blochem. 122, 429-436

19. Zwaal, R.F.A., Bevers, B.M., Comfur1us, P. (1986) In: Blood coagulat1on (Zwaal, RFA. and Hemker, HC., editors), 141-169, Blsevier, Amsterdam

20. Jesty, J., Nemerson, Y. (1974) J. Blol. Chew. 249, 509-515

21. Radcliffe, R*, Nemerson, Y. (1975) J. B101. Chem. 250, 388-395

22. Nemerson, Y. (1983) Haemostas. 13, 150-155

23. B1ggs, R., Nosse1, H.L. (1961) Thromb. Diath. Haemorrh. 6, 1-4

24. Josso, F., Prou-Wartelle, 0. (1965) Thromb. D1ath. Haemorrh. 17, 35-44

25. Osterud, B., Rapaport, S.I. (1977) Proc. Nat1. Acad. Sc1. USA. 74, $5250-5264$ 
26. Jesty, J., S11verberg, S.A. (1979) J. B101. Chem. 254, 12337-12345

27. Marlar, B.A., KLels8, A.J., Griffin J.H. (1982) B1ood. 60, 1353-1358

28. 6sterud, B., Rapaport, S. (1980) scand. J. Haemat. 24, 213-226

29. Zur, M., MemexBon, Y. (1980) J. B1ol. Chem. 255, 5703-5707

30. Marlar, R.A., Griftin, J.H. (1981) Ann. NY. Acad. Sc1. 370, 325-335

31. Mort180n, S.A., Jesty, J. (1984) B100d. 63, 1338-1347

32. Enfleld, D.L., Thompson, A.R. (1984) Blood. 4, B21-831

33. Hemker, H.C. (1984) Scand. J. Haemat. 33, 11-19

34. Reutelingsperger, C. In: Vascular anticoagulant - a new physiological ant 1coagulant mechantim. Thes1s, Mastricht (1987). P. 19-119

35. Rosenberg, R.D. and Damus, P.S. (1973) J. B101. Chem. 248, 6490-6505

36. Jesty, J. (1978) Arch. Blochem. Blophys. 185, 165-173

37. Rosenberg, J.S., Mckenna, P.W., Rogenberg, R.D. (1975) J. Biol. Chem. 250, $8883-8888$

38. Damus, P.S., Hleks, M., Rosenberg, R.D. (1973) Nature (London). 246, $355-357$

39. Vennevod, M.M., Laake, K., Salberg, A.K., Stromland, S. (1976) Thromb. Res. 9, 457-466

40. Telesforo, P., Semero, N., Verstraete, M., Collen, D. (1975) Thromb. Res. 7, 669-676

41. Beguin, S., Lindhout, T., Hemker, H.C. (1988) Thromb. Haemost. (submitted)

42. Briglnshaw, G.F., Shanberge, J.N. (1974) Thromb. Res. 4, 463-477

43. Tollefan, D.M., Blank, M.K. (1981) J. C11n. Invest. 68, 589-596

44. Hunderwald, P., Schenk, W.J., Port, H. (1982) Thromb. Res. 25, 177-191

45. Parker, K.A., Tollefsen, D.M.(1985) J. Bio1. Chem. 260, 3501-3505

46. Tollefвen, D.M., Pestka, C.A., Monafo, W.J. (1983) J. B1ol. Chem. 258, $6713-6716$

47. Bertins, R.M., van der Linden, I.K., Rngesser, L., Muller, H.P., Bromer E.J.P. (1987) Thromb. Maemost. 57, 196-200

48. Gr1ff1n, J.H., Evatt, B., Ztmerman, T.S., Klelss, A.J., Mideman, C. (1981) J. C11n. Invest. 68, 1370-1373

49. Vigano, S., Mannucc1, P.M., Salinas, S., Botasso, B., D Angela, A., Marlan1, G. (1983) Thromb. Haemost. 50, 310

50. Broekmans, A.H., Bertina, R.H., Loeliger, B.A., Hofmann, V., Klingemann, H.G. (1983) Thromb. Haemost. 49, 251 
51. Esmon, N.L., Owen, N.G., Esmon, C.T. (1982) J. Blol. Chem. 257, 859-864

52. Walker, F.J. (1981) J. Blol. Chem. 256, 11128-11131

53. Vermeer, C. (1986) In: Blood coagulation (Zwaal, R.F.A. and Bemker, H.C. editors), 87-101, Elsevier, Amsterdam.

54. Esmon, C.T., Suttie, J.W., Jackson, C.M. (1975) J. Blol. Chem. 250, 4095-4099

55. Bel1, R.G. (1978) Fed. Proc. 37, 2599-2604

56. Henker, H.C., Veltkamp, J.J., Kensen, A., Loellger, E.A. (1963) Nature (London) 200,589

57. Josso, F., Lavergu, J.M., Gouant, O., Prou-Wartelle, 0., Souller, J.P. (1968) Thromb. Diath. Haemorrh. 20,88

58. Hemker, H.C., Muller, A.D. (1968) Thromb. Dlath. Baemorrh. 20, 77-87

59. Olson, R.E., Sutt1e, J.W. (1977) Vitam. Horm. 35, 59-108

60. Sutt1e, J.W. (1979) Drug. Ther. 9, 63-71

61. Hemker, H.C., Hamuly6k, K., Beguin, S. (1986) In: Antlcaagulant Therapy. 13-23, Bds: 〈Boche〉, Basle, Switzerland

62. Bangham, D.R., Woodward, P.M. (1970) World. Health. Organ. Bu11, 42, 129-149

63. Cines, D.B. (1986) CHEST 89, 420-426

64. Buchanan, M.R., Boneu, B., Ofosu, F., Hirsh, J. (1985) Blood. 65, 198-201

65. ChIu, H.M., Hirsh, J., Yung, W.L., Regoeczl, E., Gent, M. (1977) Blood. $49,171-184$

66. Choay, J., Petitou, M., Lormeau, J.C., Sinay, P., Casu, B., Gatt, G. (1983) Blochem. Blophys. Res. Comm. 116, 493-499

67. Holmer, E., Mattson, C., Milsson, S. (1983) Thromb. Res. 32, 381-391

68. Fareed, J., Walenga, J.M., W1111amson, K., Bmanuele, R.M., Kumar, A., Hoppensteadt, D.A. (1985) Sem1n. Hemost. Thromb. 11, 56-74

69. Koller, M., Schoch, U., Buchmann, P., Larglader, P., Felton von, A., Fr1ck, P.G. (1986) Thromb. Haemost. 56, 243-246

70. Fan, H.Z., Chen, J.D., L1n, K.Z. (1983) China. Acta. Pharmacologea Sinlca - 29,53-61

71. LI., J.Z., Bao, C.X., Chen, G.Z., Zhang, G.Z. (1985) China. Acta. Pharmacologica. Stnica. 6, 107-110 

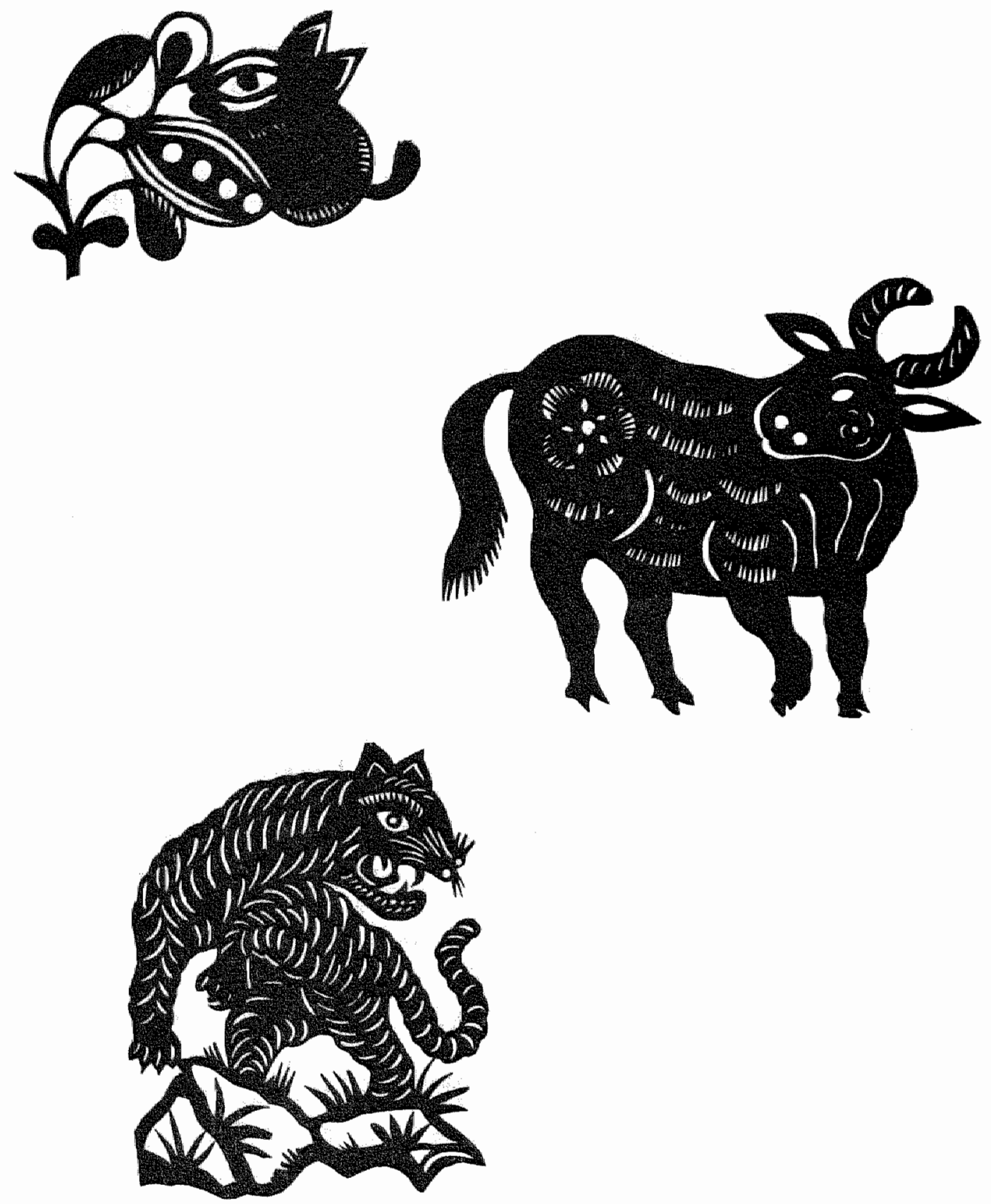
CHAP TER II

THE IMPORTANCE OF FACTOR IX ACTIVATION IN THROMBOPLASTIN-DEPENDENT COAGULATION (THB JOSSO PATHWAT) IN PLASMA

SUMMARY

In this chapter a study of the importance of factor IX activation in thromboplastin-dependent coagulation (the Josso pathway) In plasma 1 s described. piluted, $\mathrm{CaCl}_{2}$-contalning thromboplastin solutions were used to trigger the coagulation in plasma from the congenital factor IX and factor VIII deficient patients In the presence and the absence of added factors $\mathrm{IX}$ and VIII and the generation of thrombin activity in these experimental systems was mont tored.

When coagulation is triggered with the high thromboplastin concentrations normally used in clinical routine tests, the generation of thrombin activity in congenital factor IX deficient plasma before and after reconstitution th purifled factor $I X$ appears independent of the amount of factor IX (the thrombin generation curves in both reaction wature are similar). When, however, the coagulation is triggered with low thromboplastip concentrations, a clear dependency of the generation of thrombin activity on the concentration of factor IX becomes evident at factor IX concentrations lower than $30 \mathrm{nM}$ (about 40 \% clotting factor activity). Pactor VIII aems to be a compulsory cofactor for this factor IX activity because the thromblin generation at optimal factor IX concentration is at111 dependent upon the amount of factor VIII present.

It can be concluded that the factor IX activation in thromboplastindependent coagulation is of physiological importance. This pathway appears increasingly important when low anount of thromboplastin are present. 


\section{INTRODOCTION}

Blood coagulation la based on a complex series of emzymatic conversions of gerlue protiage zyageng lato active serine proteases $(1,2)$. In the classlcal view, the activation can be accomplished via two distinct pathways: the Intrinefic pathway and the extrinsic pathway. The Intrinsic pathway 18 Initiated by the so-called contact activation, which lis triggered when blood comes In contact wth damaged vascular endothelium or wth forelgn surfaces such for fnstance glass (3,4). The initlal steps of thlo pathway lavolve the four contact factors, factor XII, prekall1krein, high nolecular veight kininogen, factor $X I$, and the two antihemophlliac factors, the factors IX and VIII. Contact activation results in the conversion of factor $x$ into factor $x_{a}$.

The extrinsic pathway is initiated when blood is exposed to tissue thromboplastin, the reaction sequences involves interaction of factor VII and tissue throwboplastin and subsequent activation of factor $X$ ( 5 ). Thus both classical pathways converge in the activation of factor $x$. Later reaction sequences, the conversion of prothrowbin to thrombla and that of fibrinogen to flbrin, are cominon to both pathways.

Evidence for a close interrelationship of the classical coagulation pathways has accumulated, however. Biggs and Nossel found that hemophilla plasma did not generate normal amounts of thrombin activity when plasma coagulation was triggered wh a diluted thromboplastin solution (6). Josso and prou-Wartelle described that factor VII was essential for the procoagulant activtty of diluted thromboplastin and postulated the importance of antihemophilic factors in the thromboplastin-dependent pathway (7). Direct evidence for an essential linkage between both classlcal pathways was obtalned by foterud and Rappaport (8). They clearly showed that a wixture of factor VII and thromboplastin could activate factor IX in partialiy purtfled system. This activation step was studied further by several groups and It was clearly showm that factor VII (a) in the presence of thromboplastin can activate both factor $\mathrm{IX}$ and factor $\mathrm{X}(9-15)$.

Although numerous studles have postulated that the factor IX activation in thromboplastin-dependent coagulation is of Important pathway, attention Is wostly focussed on the factor $X$ activation. A clear evidence to which the generation of thrombin activity is mediated via thromboplastin-induced 
factor IX activation pathway is lacking, however. From a physiological point of view prothrombinase activity and thrombin generation are wore important. In this respect we studied the effect of thromboplastin on the generation of thrombin activity in factor IX and factor VIII deficient plasma. The studies described in this chapter were carried out in order to obtain a better impression of the relative importance of the thromboplastin-1nduced factor IX activation ( 1 .e. the Josso pathway).

MATERTALS AND METHODS

Hemophilla patients

Dlagnosis of both hemophilia $A$ and $B$ was based on a positive family history with a recessive sex-linked inheritance, joint and deep muscle bleeding and prolonged partial thromboplastin time.

The activity of the clotting factors VIII and IX was quantitatively determined by a one-stage method according to the standard procedure of the manufacturer (Behring Institute, West Germany). The factor VIII activity in hemophilla A plasma and the factor IX activity In herophilia B plasma were $<1 \%$ and $1.5 \%$ respectively.

\section{Hemophilic plasma}

Blood from hemophilia patleats (A and B) was collected in trisodium citrate (9 volumes of blood to 1 volume of $0.13 \mathrm{M} \mathrm{tribodium} \mathrm{citrate)} \mathrm{and}$ centrifugated for 15 minutes at $3000 \times \mathrm{g}$ at $4^{\circ} \mathrm{C}$. Plasmas were stored in 1 mil allquots at $-80^{\circ} \mathrm{C}$.

\section{Thromboplastin}

Human braln thromboplastin was prepared by a modification of the nethod of Owen et al (16). The crude preparation obtalned was homogenized in a potter Elvehjem homogeniser for 3 minutes, centrifugated for 15 minutes at $2000 \times \mathrm{g}$ at room temperature. The preparation was stored in 1 al aliquots at $-20{ }^{\circ} \mathrm{C}$. Prior to use the preparation was thawed, diluted wth $0.05 \mathrm{~K}$ 
Tr18-HC1 (pH 7.35) contalaing $0.1 \mathrm{M} \mathrm{CaCl}_{2}$ and prewarmed for 1 hour at $37^{\circ} \mathrm{C}$.

\section{Phospholipld}

Phosphollpld vesicles containing $25 \%$ phosphatldylserine (PS) and $75 \%$ phosphatidylcholine (PC) were prepared as described previously (17).

\section{Protelns}

Bovine factor IX was prepared as described by Fujikawa et al (1B). Bovine factor vIII prepared according to Vehar and Davie (19) wth the modiflcation by van Diefjen et al (20).

\section{Chromogenic subgtrate}

Chromogentc aubstrate S 2238 was obtained from Kabl vitrum (stockholm, Sweden).

Measurement of thrombin generation in plasma

For the measurement of thrombin generation the procedure described by Hemker et al (21) was used. Briefly, $240 \mu 1$ of plasma and $60 \mu 1$ of buffer (Tr1s-HC1, pH 7.35) were incubated for 4 minutes at $37^{\circ} \mathrm{C}$. The thrombin generation was triggered by the addition of $60 \mu 1$ of thromboplastin solution contialing $0.1 \mathrm{M} \mathrm{CaCl}_{2}$. At fixed time intervals, $10 \mu 1$ allquots of the Incubation alxture were subsampled Into tubes containing $465 \mu 1$ of buffer (0.05 H Tr1g-HC1, $0.1 \mathrm{M} \mathrm{NaCl,} 0.5 \%$ albumin and 0.02 EDTA, pH 7.9) and $25 \mathrm{\mu l}$ of $\mathrm{S2238}(4 \mathrm{mM})$ at $37^{\circ} \mathrm{C}$. The subsampling tubes were Incubated for 2 winutes at $37^{\circ} \mathrm{C}$, and then the reaction was stopped by the additlon of $300 \mathrm{jl}$ of concentrated acetic acid. The pipettes for sampling and stopping the reaction were connected to an Apple Ile computer, programed to record the monent of sampling and the moment of stopping the reaction. The optical density was read at 405 na in a spectrophotometer (LKB-U1trospec). From the change In optlcal density and the time interval between subsamilng and stopplag the $\triangle 0 . D . / m i n$ was automatically calculated. 
Measurement of the decay constant of endogenous thrombin

Brief1y, $120 \mu 1$ of plasma and $24 \mu 1$ of buffer (Tris-HCl, pH 7,35) were incubated for 4 milnutes at $37^{\circ} \mathrm{C}$. Thrombin generation in plasma was triggered by the addition of $30 \mu \mathrm{l}$ of thromboplastin solution. At the moment after the maximal thrombin formation, $6 \mathrm{\mu l}$ of Soybean trypsin Inhibitor solution (SBTI, $10 \mathrm{mg} / \mathrm{ml}$ ) was added to the reaction aixture. At fixed intervals after addition of SBTI, 10 il aliquots of the reaction mixture were subsampled Into the tubes contalning S2238 (4 mM) and EDTA (20 mM) by using the time recording pipette. The determination was the same as that described for the measurement of thrombin generation.

The data obtained from thrombin amidolytic activity at the different time points $\left(C_{t}\right)$ were fitted to the formula $C_{t}=C_{R}+C_{0} e^{-k t}$, which glves the level at the moment of SBTI addition $\left(C_{R}+C_{O}\right)$, the steady end level $\left(C_{R}\right)$ and the decay constant $(k)$. The parameters were determilned by means of an ordinary least squares fit of the model to the data. The parameter values that minimize the sum of squared residuals were calculated using the Box-Kanemasu modification of Gauss' method (22). The Iinear equations were solved by meang of Haussholder transformatlons. The decay constant thus obtalned is the sum of the $\alpha_{2}$-macroglobulin dependent decay constant $\left(k_{2}\right)$ and the antithrombin III dependent decay constant $\left(k_{1}\right)(21)$.

\section{Estimation of the prothrombin conversion velocity}

The prothrombin conversion velocity (prothrombinase, $n \mathrm{~min}^{-1}$ ) was callculated by a computer using the thrombin generation data and the experimental1y determined decay constant of endogenous thrombin. As described above, the decay constant of endogenous thrombin obtained is the sum of $k_{2}$ and $k_{1}$. The $k_{2}$ used $1 \mathrm{~s} 0.232 \pm 0.004 \mathrm{mim}^{-1}(\mathrm{n}-25)$. For technilcal details see ref. 21 . 
RESULTS

Generation of thrombln activity in factor IX deficlent plasma after trlggerling coagulation with thromboplastin.

To Investigate the effect of factor IX on thrombin generation after triggering coagulation with thromboplastin, congental factor IX deficlent plasma waed. Part of the factor IX deflclent plasma was reconstituted wth 90 nM factor IX (about $100 \%$ clotting activity) and another part was used rthout the addition of factor $\mathbb{I X}$. When the coagulation was triggered with varlous concentrations of thromboplastin, the curves of thrombin generation In both plasma preparations shown in figure 1 were obtained.

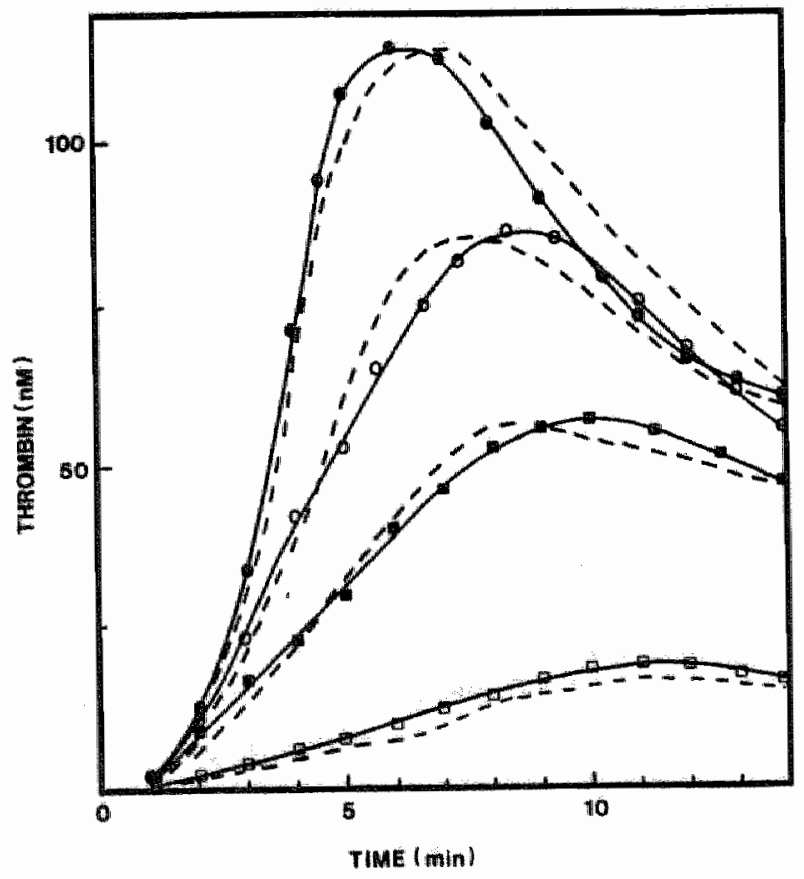

Fig. 1. Generation of thrombin activity in factor IX deficient plasma before and after reconstitution with factor IX $(90 \mathrm{nM})$.

Coagulation was triggered th a series of dilutions of thromboplastin. Pactor IX defficlent plasma: (- - -); Reconstituted plasma* ( $(-$ ). Pinal thromboplastin dilution in the reaction mixture: $1 / 240(-0) ; 1 / 360(0-0) ; 1 / 480(-1 / 6) ; 1 / 00(\square-D)$. 
It was unexpected that the curves of thrombin generation in the congenital factor IX deficlent plasma and in the reconstituted plasma were very similar in the thromboplastin concentration range studied (final thromboplastin dilution in the reaction mixture: $1 / 240-1 / 600$ ). Figure 1 also gives the Impression, however, that the relation between the thromboplastin concentration and the maximal amount of thrombin formed 18 not linear; thrombin generation seems to be markedly reduced at the highest

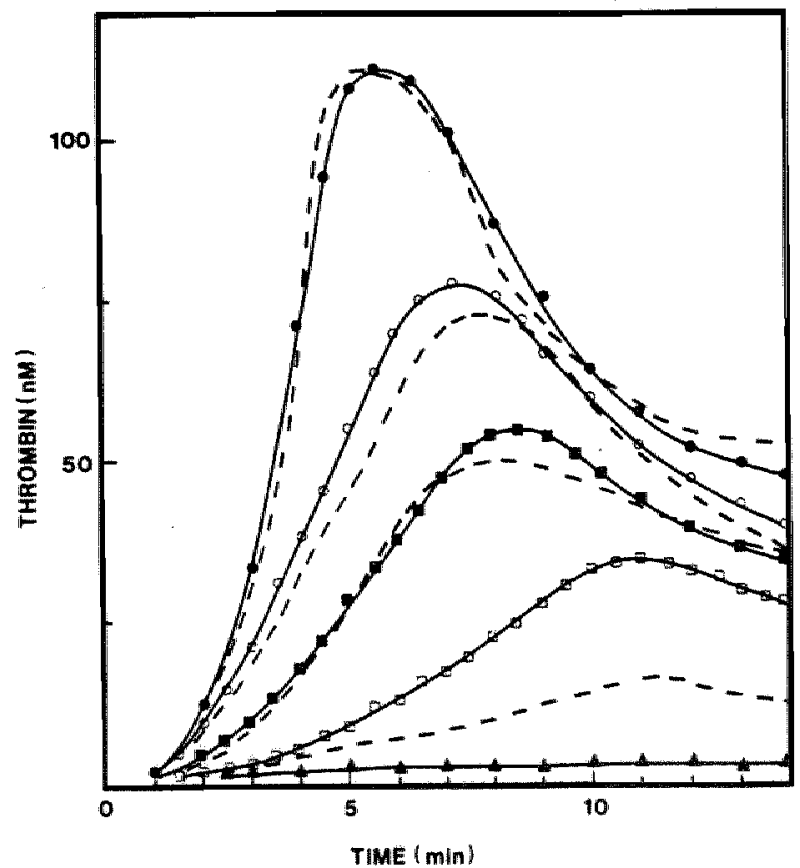

P1g. 2. Generation of thrombin activity in factor IX deficient plasma before and after reconstitution wth factor IX (90 nM).

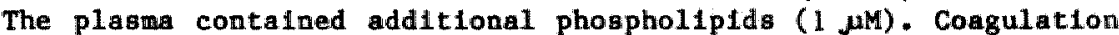
was triggered with a series of dilutions of thromboplastin. Factor IX deficlent plasma: ( $-\ldots)$; Reconstituted plasma: ( - ). Final thromboplastin dilution in the reaction alxture: $1 / 240(-)$; $1 / 360(\mathrm{O}-\mathrm{O}) ; 1 / 480(\square-) ; 1 / 600(\mathrm{D}-\mathrm{D}) ; \mathrm{CaCl}_{2}$ solution without thromboplastin ( ) 
thromboplastin dilution. This observation could point to a shortage of phospholipids in the reaction alxture, because at the highest thromboplastn dilutions the avallable phospholipld/water interface could become the liditing factor in thrombin generation. We therefore repeated the experiments but this time incluced phosphollpid vesicles in the reactlon mixtire (final concentration 1 MM), so that the amount of tissue factor varles but the amount of phospholipld not. When a $\mathrm{CaCl}_{2}$ solution was added to the Incubation aixture no thrombin generation was observed. Frow this obgervation conclude that the phosphollpid lixture per se does not initiate thromin formation and the contact activation is neglectable in oux system.

Flgure 2 shows that in the presence of additional phospholipld vesicles the maximal amount of thrombin formed $1 s$ greater in the reconstituted plasma than in the congenital factor IX deflcient plasma and that the influence of factor $I X$ on thrombin generation is more important at low thromboplastin concentration.

Generation of prothrombinase activity in factor IX deficlent plasma after triggering coagulation with thromboplastin.

Information about the prothrombinase activity can be derived from the thrombin generation curves shown in figure 2 by computer processing. To allow computation the decay constant of endogenous thrombin activity nust be determined. The decay constant ( $k$ ) of endogenous thrombin 1 factor $I X$ deficlent plasma was $1,19 \mathrm{~min}^{-1}$. As has been described in the section Materials and Methods, the overall decay is the effect of thrombin Inhibition by antithromblin III and by $\alpha_{2}$-macroglobulin. Therefore, the decay constant $k$ Includes the decay constant of thrombin by antithrombin III $\left(k_{1}\right)$ and the decay constant of thrombin by $\alpha_{2}$-macroglobulin ( $\left.k_{2}\right)$. For the $\alpha_{2}$-macroglobulin dependent process the decay contant determined in normal plasma was used $\left(k_{2}=0.232 \pm 0.004 \min ^{-1} ;=25\right)(21)$. 


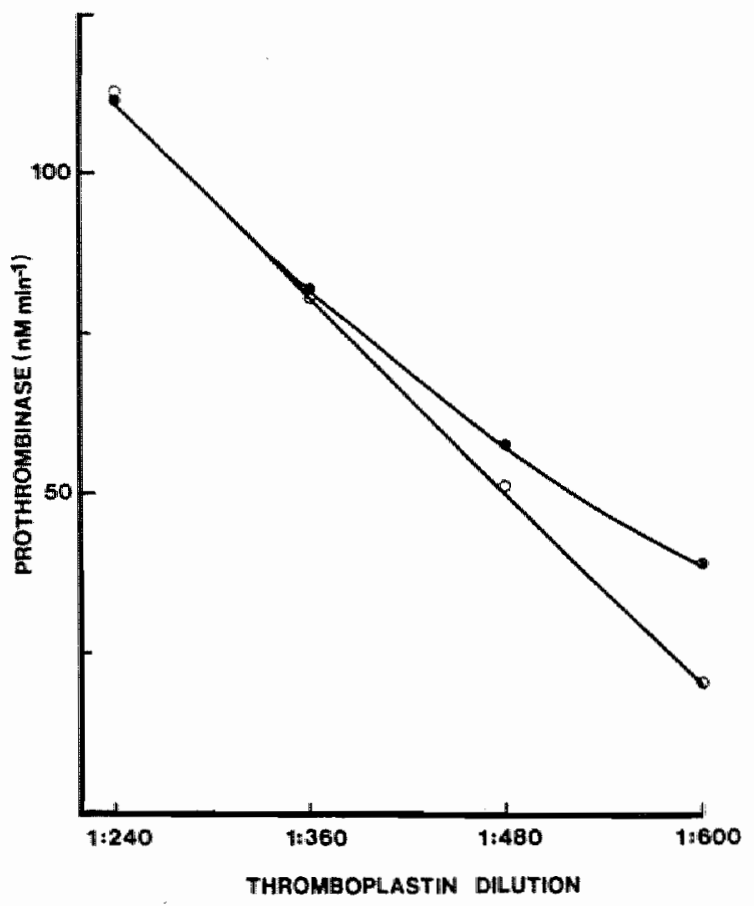

F1g. 3. Maxima1 prothrombinase activity in factor IX deficlent plasma before and after reconstitution with factor IX (90 nM). The plasmas contained additional phospholipids ( $1 \mathrm{\mu M})$.

Coagulation was triggered with a series of dilutions of thromboplastin. Factor IX def1cient plasma: (O-O); Reconstituted plasma: $(0-0)$.

The prothrombinase data obtalned by the computer program are plotted as a functiom of thromboplastin dilution in figure 3 . It can be seen from this flgure that at thromboplastin dilutions greater than 1 : 480 , the prothrombinase activity in congenital factor IX deflcient plasma 1 s lower than that in the reconstituted plasma. There 18 a clear parallel between the effect of factor IX on thrombin generation (figure 2) and on prothrombinase activity (figure 3 ). 
Factor IX dependency of thrombla actlulty and prothromblnase activity after triggering coagulation wh thromboplastin.

In order to quantify the factor IX dependency of thrombin generation after triggering coagulation with chromboplastin, various amounts of factor IX (15-90 a were added to congenttal factor IX deficient plasma. After addition of phospholipld vestcles (1 Hil) coagulation was triggered with thromboplastin (final dilution $1: 600$ ). The curves of thrombin generation obtalned are shown in figure 4.

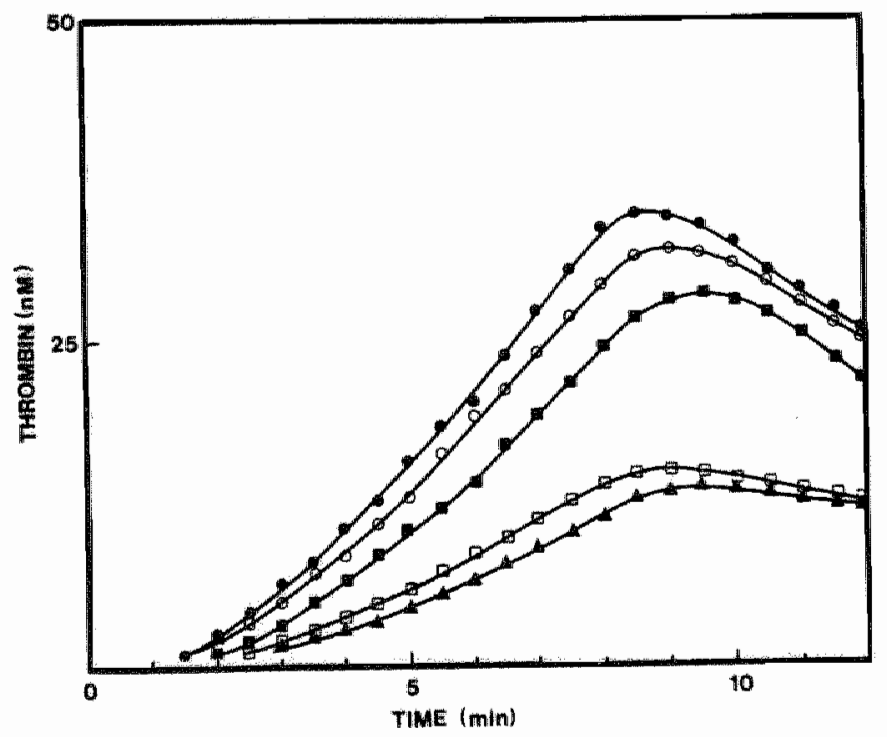

Ptg. 4. Influence of factor IX on thrombin generation. The plasmas contained additional phospholipid ( $1 \mathrm{jM})$. Comgulation was triggered 1th thrombopiasin (fimal dilution 1/600). concentration of factor $I X$ in the reconstituted plasma: 90 nM $(0-0) ; 60 \mathrm{nM}(O-0) ; 30 \mathrm{mM}(-)) ; 15 \mathrm{nM}(\square-\square) ;$ no additlonal factor ix $(\Delta-\infty)$. 
It is clearly seen in this figure that in the concentration range tested factor IX stimulates thrombin generation, but there is no linear relationship between the factor IX concentration and the thrombin formation. At a concentration of $15 \mathrm{nM}$ factor IX the thrombin formation was only slightly increased over the control value (no additlonal factor IX). A further increase in the factor IX concentration stimulated thrombin generation and the process showed the characterisitics of a saturation phenomenon. When prothrombinase activity was calculated from the thrombin generation curves, the same tendency was observed (flgure 5 ).

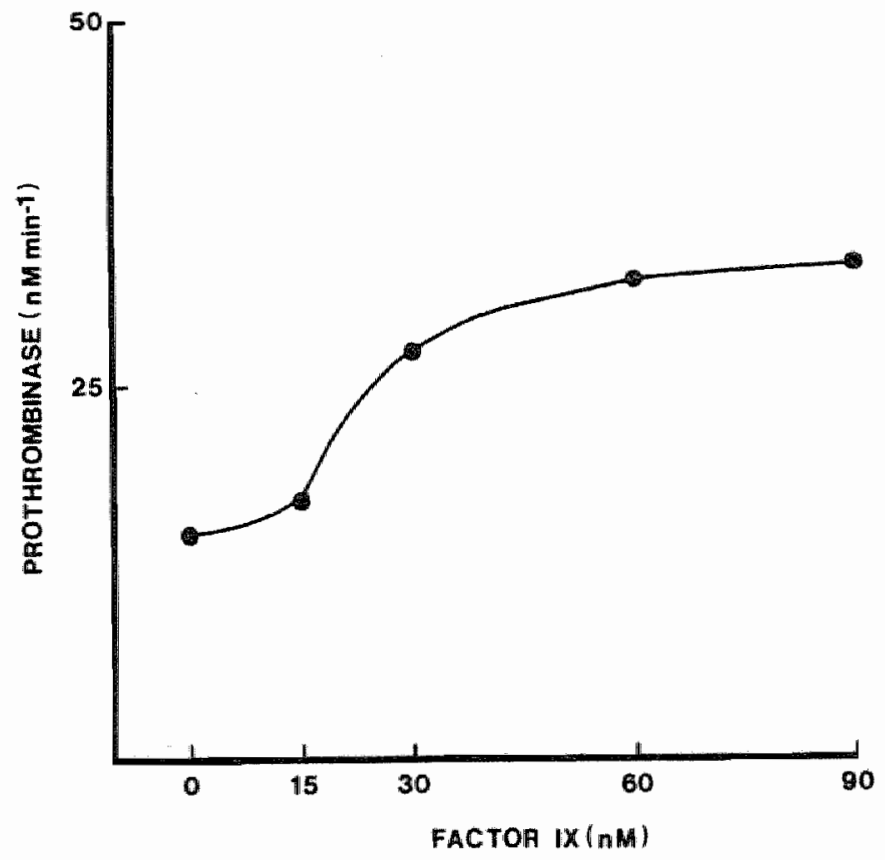

Pig. 5. Influence of factor IX on prothrombinase activity. For experimental detalls see the legend to figure 4. 
Generation of chrombin activity 1 factor VIII deficlent plasma after triggerimg cogulation th thromboplastin.

As factor vIII 1 involved a cofactor in the activation of factor $X$ by factor $\mathrm{IX}_{a}$ we also studled the effect of factor VIII on thrombin generathon after triggerting coagulation by thromboplastia. One part of the congenftal factor VIII deflelent plasma was reconstituted wth $\mathbb{V}$ factor VIII (about 100\% clotting activity) and another part of congenital factor VII deflcient plasma was used whout the addition of factor VIII. After addition of phospholipids ( 1 JM) to both plasma preparations the coagulation triggered wh thromboplastin (f1nal dilution 1:600). In a control experiment $\mathrm{CaCl}_{2}$ solution $(0.1 \mathrm{M})$ was used instead of the thromboplastin solution. The thrombin geveration curves obtained are shown in flgure 6. It was evident that the presence of factor viII clearly stmulates the thrombin generation. The maximal amount of thrombin formed In the reconstituted plasma was about two-fold compared to that formed in the congenttal factor VIII deficlent plasma.

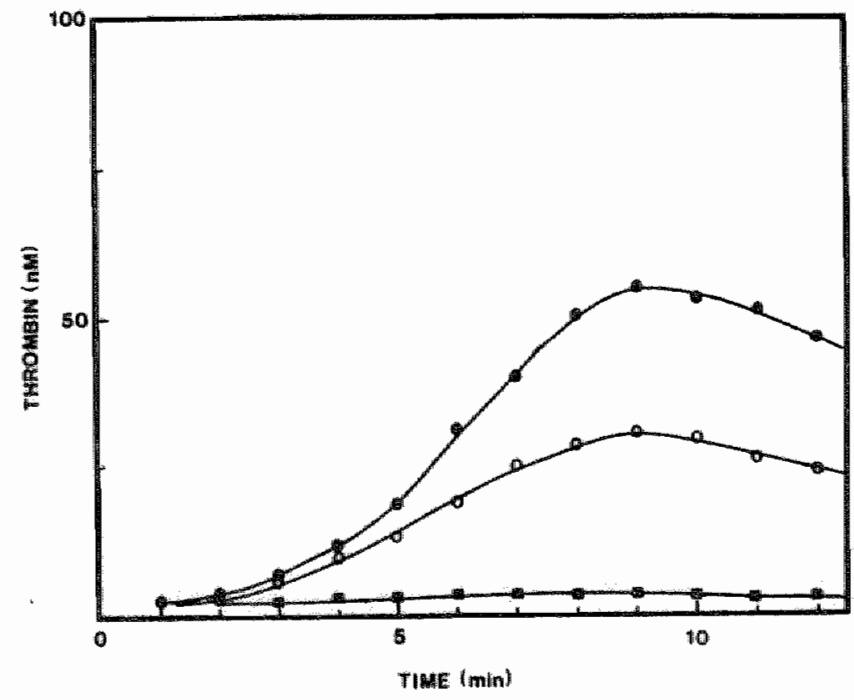

FIg. 6. Generation of thrombin activity in factor VIII deficlent plasma before and after reconstitution with factor VIII $(1 \mathrm{v} / \mathrm{ml})$. The plasma contalned additlonal phospholiplds ( 1 MM). Coagulation was triggered with thromboplastin (flnal dilution 1/600). Factor VIII deficlent plasma: ( $\mathrm{O}-\mathrm{O})$; Reconstituted plasma: ( -0 ); $\mathrm{CaCl}_{2}$ solution thout thromboplastin: (1) 
Gemeration of prothrombinase activity in factor VIII deflclent plasma after triggering coagulation with throuboplastin.

The thrombin generation curves shown in flgure 6 were agatn processed by the computer to obtain prothrombinase activity data. The results of these calculations are shown in figure 7. Addition of factor vII to the congentcal factor VIII deflclent plasma caused two-fold lncrease in the maximal amount of prothrombinase activity generated. This enhancenent in prothrombinase activity upon addition of factor VII parallelled the enhancement in the process of thrombin generation (see fig. 6).

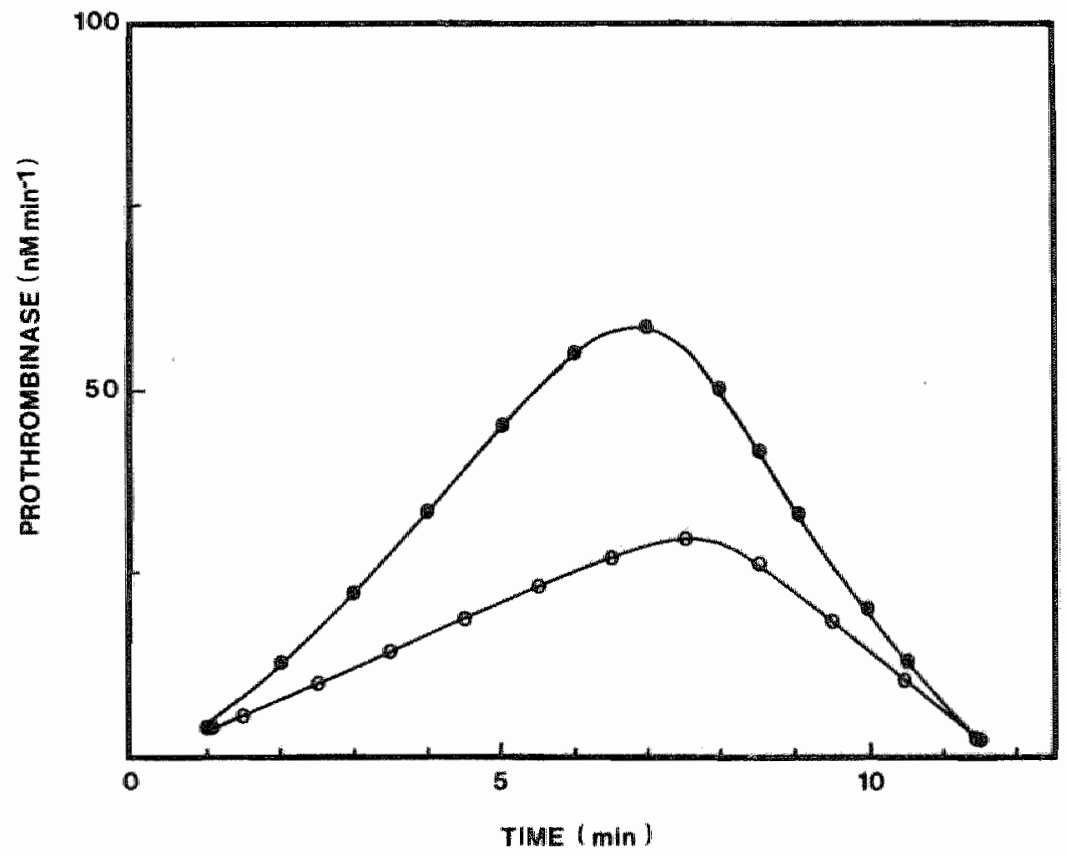

Fig. 7. Prothrombinase activity in factor VIII deficlent plasma before and after reconstitution wth factor VIII (1U/m1). Ror experimental. detalls see figure 6 . 
Bactor VIII dependency of thromblin activity and prothrombinase activity after triggering coagulat 1on with thromboplastin..

In order to quantify the factor VIII dependency of thrombin generation after triggering coagulation wth thromboplastin, varlous amounts of factor VIII $(0.2-1 \mathrm{v} / \mathrm{mi})$ were added to congenital factor VIII deficient plasma. Add1tonal phosphollplds ( $1 \mathrm{jM}$ ) were added to the plasma preparation and the coagulation triggered wh thromboplastin (final dilution 1:600). The thrombin generation data and the prothrombinase activity data are shown in the figures 8 and 9 , respectively.

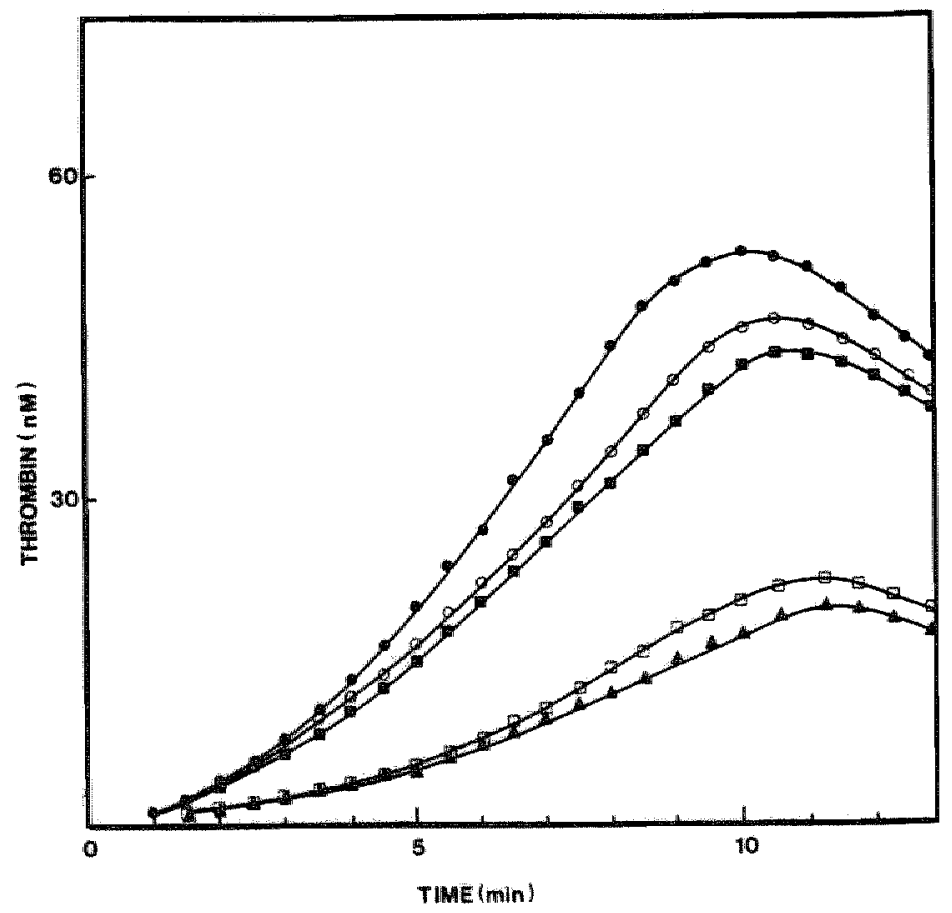

PIg. 8. Influence of factor VIII on chrombin generation. The plasmas contalued additional phospholipid ( 1 JM). Coagulation was triggered with thromboplastin (final dilution 1/600). Concentration of factor VIII in the reconstituted plasma: $1.0 \mathrm{U} / \mathrm{ml}$ $(0-0) ; 0.5 \mathrm{U} / \mathrm{ml}(0-0) ; 0.3 \mathrm{U} / \mathrm{ml}(\mathrm{v}) ; 0.2 \mathrm{U} / \mathrm{ml}(\mathrm{D}-\mathrm{a}) ;$ no additional factor VIII $(-M)$. 
$-29-$

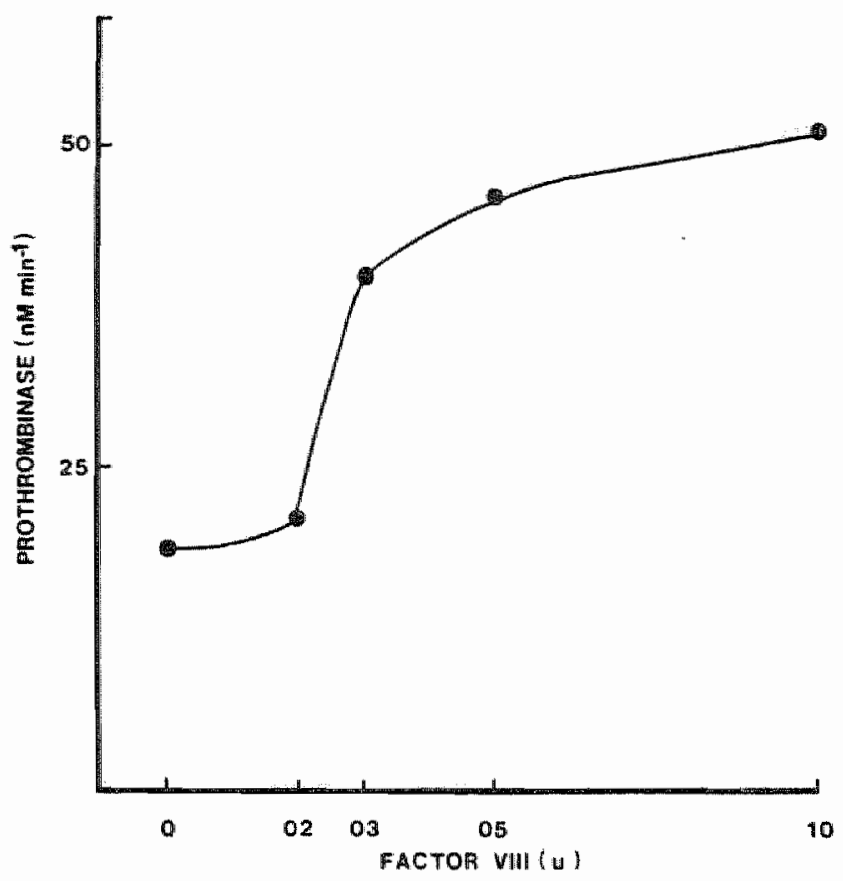

Fig. 9. The Influence of factor VIII on prothromblnase activity. For experimental details see the legend to figure 8 .

When a low amount of factor VIII $(0.2 \mathrm{U} / \mathrm{ml})$ added, the maximal amount of thrombi generated was only slightly higher than in that in the congenital factor VIII deficient plasma. A further increase in the factor VII concentration stimulated thrombin generation and gain the dependency showed saturation characteristics. The prothrombinase activity data showed the same tendency (figure 9). 
DISCUSBION

In this chapter a atudy of some aspects of the interrelationship between the fntringlic and the extriasic pathwas of coagulation ils deserlbed. Diluted, $\mathrm{CaCl}_{2}$-comtalming thromboplastin solutions were used to trigger caagulation in congenital factor IX and factor vII deficient plams to wheh various amounts of the purlfled factors were added and the generation of thrombln activity and the prothromblnase activity in these experimental systems were registrated.

When the coagulation of factor IX deficlent plasma was triggered with a serles of dilutions of thromboplastin, the relation between the maximal amout of thrombin formed and the thromboplastin concentration is mot 11near. At high thromboplastin dilution $(1 / 600)$, the generation of thrombin activity in factor IX deflclent plasma showed to be markedly reduced. This result is in accordance wh the observation of Biggs and Nossel, who reported an abnormal amounts of thrombin in plasma of both hemaophilia A and hatemopht1la $B$ patients after triggering coagulation with low amounts of thromboplastin (6). In our experimental system, this reduction of thrombin actlvity was not reverised by the addition of factor IX $(90 \mathrm{nM})$ to the factor IX deficlent plasma, although this amount of factor IX is sufficlent to restore the clotting activity to normal level. When, however, phosphollpid vesicles were added to the factor IX deficient plasma the Hmportance of factor IX $1 \mathrm{n}$ the process of thrombin generation after trigger 1 g coagulation with small amounts of thromboplastin became evident. This is Indicated that at higher thromboplastin dilution the amount of phosphollpld wallable becomes rate 1imitlag factor. For this reason additomal phospholipids (flual concentrations ljM) were gystematically included in the reaction ixture.

It to dent that the influence of factor IX on thrombin generation is more liportant at higher thromboplastin dilutions. Such an effect $1 \mathrm{~s}$ also reflected In the prothrombinase data. These results show that in situations. where low amounts of thromboplastin are avallable the interaction between intrinstc and extrinsic pathway becomes lacreasingly important.

The effect of factor VIII on thrombln generation after triggering. coagulation th small amounts of thromboplastin ls shown to stimilar as seen in factor IX deflclent plasma after reconstritution with purlfled 
factor IX. As could be expected, the effect of factor VIII on thrombin generation in congenital factor VIII deficient plasma closely resembles the effect of factor IX on thrombin generation in factor IX deficient plasma. When coagulation is triggered with a small amount of thromboplastin, the presence of factor VIII stimulates thrombin generation and prothrombinase activity; the phenomenon shows saturation characteristics. The role of factor VIII as a cofactor In the factor $X$ activation by factor IX has well been studied (23-25). In the absence of factor VIII the rate of factor $X$ activation by factor $I X_{a}$ is extremely slow, even in the presence of a sufficlent amount of phospholipids. Factor VIII brings about a $2.10^{5}$-fold increase in the rate of factor $X$ activation by factor $\mathrm{IX}_{\mathrm{a}}$ (25).

The dependency of thrombin generation on factor IX and factor VIII after triggering with small amounts of thromboplastin is only evident at factor IX concentrations lower than $30 \mathrm{mM}$ (about $40 \%$ of normal clotting activity) or factor VIII concentrations lower than $0.3 \mathrm{U} / \mathrm{ml}$ (about $30 \%$ of normal clotting activity). These wil not be detected wh a routine prothrombin time test, because the amount of thromboplastin used in the prothrombin time test 18 too hllgh. For this reason these tests "bypass" the factor VII/thromboplastin - factor IX pathway and therefore plasma from haemophilia patients wil give a mormal thrombin gemeration.

The interaction between the intrinsic and the extrinsic pathways of coagulation might also explain several clinical observations. Some patients with a deflclency of factor VII have a serlous hemorrhaglc diathesis indeed, whereas patients with deflciencles In the contact activation aystem have no significant hemorrhagic diathesid, but on the contrary may be assoclated with thromboembollc eplsodes. The first patient described with Hageman tralt died of pulmonary embolisms (26). Factor XI deficlency which presents as alld hemorrhage take an Intermedlate position.

The results presented in this chapter show the importance of the factors IX and VIII In the thromboplastin-dependent coagulation proces in those situations 1m which trace amounts of thromboplastin are present. This interrelation between the extrinsic and instrinsic pathways could be able to explatn properly why hemophilia patients in the deficlencles of the intrinsic pathway are not compensated by the intect extrinsic pathway. 
14. Morrison, S.A., Jesty, J. Tissue factor dependent activation of tritium-labeled factor IX and factor $X$ in human plasma. Blood. 63, $1338-1347,1984$

15. Enfleld, D.L., Thompson, A.R. Cleavage and activation of human factor IX by serine proteases. Blood 4,821-831, 1984

16. van Dam-Mleras, M.C.E., Huller, A.D., van Dleljen, G., Henker, H.C. Methods of enzywatic analys1s. Bnzyms 3: Peptldases, proteinases and their inhibltors. Vo1. V, 352-394, 1984, Verlag Chemie, Welnheim, Eds: H.U. Bergmeljer

17. Rosing, J., Tans, G., Govers-Rlemslag, J.W.P., Zwaal, R.F.A., Hemker, H.C. The role of phosphollptds and factor $V_{a}$ in the prothrombinase complex. J. Biol. Chem. 255, 274-283, 1980

18. Fuftkawa, K., Legaz, M.E., Kato, H., Davie, E.W. The mechanism of activation of bovine factor IX (Christmas factor) by bovine factor $X I_{a}$ (activated plasma thromboplastin antecedent). Blochemistry, 13, $4508-4516,1974$

19. Vehar, G.A., Davie, E.W. Preparation and properties of bovine factor VIII. Biochemistry. $19,401-410,1980$

20. van Dieljen, G., van Rijn, J.L.M.L., Govers-Rienslag, J.W.P., Henker, H.C. Assembly of the intrinsic factor $X$ activating complex; interactions between factor $\mathrm{IX}_{a}$, factor $\mathrm{VIII}_{\mathbf{a}}$ and phospholipld. Throwb. Haemost. (Stuttg.) 53, 396-400, 1985

21. Hemker, H.C., Willems, G.M. Beguin, S. A computer assisted method to obtain the prothrombin activation velocity in whole plasma independent of thrombin decay processes. Thromb. Haemost. 56, 9-17, 1986.

22. Hemker, H.C., WH1lems, G.M., Beguin, S. Thromblnoscopy, a personal computer program for the analysis of thrombln generation curves. Comput. Biol. Med. (submitted)

23. Hultin, M.B., Hemerson, Y. Activation of factor $X$ by factors $I_{a}$ and VIII; a speciftc assay for factor $\mathbb{I X}_{a}$ in the presence of thromblinactivated factor VIII. Blood. 52, 928-940, 1978

24. Hultin, M.B. Role of human factor VIII in factor X activation. J. Clin. Invest. $69,950-958,1982$

25. van Diefjen, G., Tans, G., Rosing, J., Hemker, H.C. The role of phospholipid and factor VIII in the activation of bovine factor $X$. J. Biol. Chem. 256, 3433-3442, 1981 
26. Ratnoff, 0.D., Rubse, R.J., Scheon, R.P. The demise of John Hageman. N. Engl. J. Ked. 279,760-762, 1968

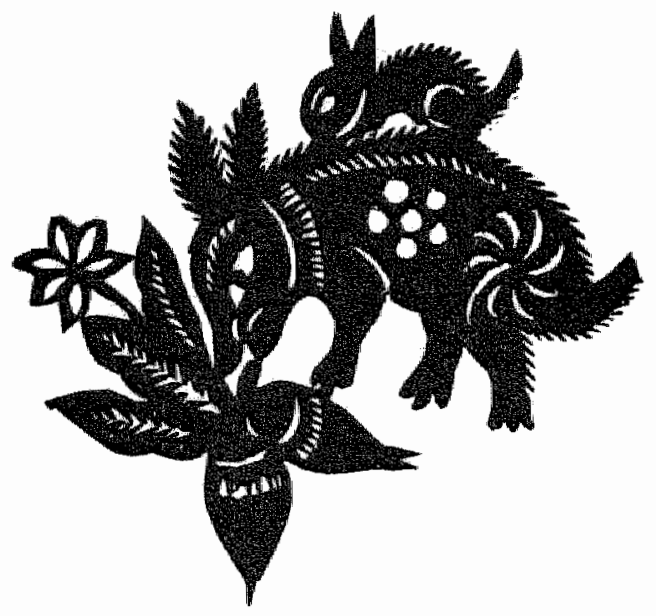


CHAPTER III

THE RBLATIVE IMPORTANCE OF THE VARIOUS VITAMIN R-DBPBNDBNT CLOTTING FACTORS OF THE PROTHROMBINASE ACTIVITY IN PLASMA OF ORALIY ANTICOAGULATED PATIBXTS

SUMAARY

In this chapter, the relative importance of the varlous vitanin R-dependent clotting factors on the prothrombinase activity in the plasma of orally anticoagulated patients is described.

Addition of purifled factors VII, IX or $X$ to plasma from deeply antcoagulated patients (Thrombotest value in the 10-15 $\mathrm{X}$ range) did not influence the amount of prothromblnase formation or the amount of thrombin formed. Only the factor II level in the plasma determines the course of thrombin generation. Addition of increasing amounts of purifled factor II, VII, IX or $X$ to plasmas deficlent in respectively factor II, VII, IX or $X$ showed that the prothrombinase activity linearily increases with the concentration of factor II added and that the concentration below which the factors VII, IX and $X$ atart to have an effect on prothrombinase activity were $5 \%, 20 \%$ and $40 \%$, respectively. The half maximal amount of prothrombinase activity was found at about $1 \%$ factor VII, 52 factor IX and $10 \%$ factor $X$ respectively.

Prom these observations we conclude that only the changes in factor II level determines the antithrombotic effect of oral anticoagulant therapy. Therefore, it seems likely that, for the control of oral antlcoagulant therapy, tests that reflect factor II activity would be sultable. 


\section{INTRODUCTION}

The coagulation protelns that are synthesized in the bepatic parenchymal cells dependent on vitamin have the cownon characteristic of the occurence of $\mathcal{Y}$-carboxylated glutamic acld residnes in the N-terminal reglon of the protelm chaln. Pactors II, VII, IX, $\mathrm{T}$ and the antlcoagulant protelne $c$ and $s$ belong to this group. Vitamin $\mathrm{x}$ stimulates the carboxylathon of these proteln in a postribosomal step of hepmic symehesis (1). The carboxylated coagulation protelns are capable of bluding to a negatively charged phospholipld surfaces via $\mathrm{Ca}^{2+}-\mathrm{brldges}(2)$. This interaction is essentid for their effective particlpation in the coagulation processes.

Vitamin $K$ antagonists, the coumarin congeners, interfere with the carboxylation of witamin K-dependent coagulation protelins, and this results. In the gynthesis of blologlcally inactive but lmunologically detectable forms. These inactive forms termed PIVRA reach the blood stream but are wable to bind to a natively charged phospholipld via $\mathrm{Ca}^{2+}$-bridges (3). Therefore the formation of at least three allelcomponent enzymatic complexes, 1.e. the factor $x$ activator formed by thromboplastin and factor WII the factor X activator (tenase, FIX - FVIII $_{\text {a }}$ - PL) and prothrombin converting activity (prothrombinase, $\mathrm{FX}_{\mathrm{a}}-\mathrm{FV}-\mathrm{PL}$ ) will be diminished by vitamin $k$ atagonist therapy. This will of course results in a diminution of thrombin generation.

Because the effect of coumarin therapy that interferes with the gynthesis of effective cloteing factors is not imediate, the preexistant eleculating clotting factors have to disappear before the level of clotting factors adapts to the new dilmished level of synthesls. The varlous factors decline wth velocitles dependent upon thelr half-1lfe times which are approxlmately: factor VII: hours, factor IX: 14 hours, factor $X: 45$ hours, factor It: 60 hours (4). shortly after the beglnning of anticoagulant therapy the levels of clotting factors will wow the following order VII $<I X<X<I I$. Dnly when factor It, the "slowest one, has adapted to the prevalling level of gynthesis the relative levels will be equal. If the therapy is stopped the velocity of reapperance is again a function of half-11fe time and the order w1I be VII $>$ IX $>\mathrm{X}>$ II. Because of fluctuations in dosage and (patho)physlologlcal clrcumstances, stable anticoagulation th all factors at the same level is less comon than 
would be desirable. Therefore knowledge of the relative importance of the level of each Individual clotting factor to the overall anticoagulant (1.e. antithrombosis) effect is of great practical importance.

For deep and stable anticoagulant effect the levels of the vitanin R-dependent clotting factors are normally regulated dow to about $20 \%$ of normal (5). This level of clotting activity is considered as an effective anticoagulant treatment. However, this estlmation of the potential clatting activity is based on an overall clotting test, 1.e. prothrombin time. The relative contribution of the individual clotting factors to this "hypocoagulability"' of plasma is not clearly understood. In this chapter, we describe the results of a study on the effect of vitamin $\mathrm{X}$-dependent clotting factors on prothrombinase activity in dicoumarol plasma.

MATERIALS AND METHODS

\section{Patients}

46 patients wh a varlety of thrombotic disorders undergoing oral anticoagulation with dicoumarol drugs were selected for this study. All patients were in the optimal therapeutic range as judged by the laboratory control of oral anticoagulant therapy (according to the standard of the Thrombose Stichting Nederland). The thrombotest values were between $10 \%$ and $15 \%$ of those found in normal plasma.

\section{Plasmas}

Blood from patients undergoing oral anticoagulant treatment was collected In trisodium citrate (9 rolumes of blood to 1 volume of $0.13 \mathrm{M}$ trisodium citrate) and centrifugated for 15 ainutes at $3000 x$ at $15{ }^{\circ} \mathrm{C}$. plasma samples from the 46 patlents were pooled and centrifugated for 1 hour at $23000 \mathrm{xg}$ at $4^{\circ} \mathrm{C}$. The pooled platelet free plasma was stored at $-80^{\circ} \mathrm{C}$. 
Thromboplasta

Human braln throwboplastin was prepared by modfflcation of the nethod of owen (6). The preparation obtalned was homogenized in a Rotter Elvehjem homogeniser for 3 minutes, centrifugated at $2000 \mathrm{x}$ for 15 minutes and stored in 1 milliquots at $-20^{\circ} \mathrm{C}$. Prior to use the preparation was thawed, d1luted $1: 40$ with 0.05 M Tris-HCl (pH 7.35) comtalning $0.1 \mathrm{M} \mathrm{CaCl}_{2}$ and prewarmed at $37^{\circ} \mathrm{C}$ for 1 hour. When normal plasma was incubated with this thromboplastin dilution under the same experimental conditions as used in the thromin generation experiments the clotting time was 80 seconds.

\section{Cephaloplastin}

Cephaloplastin was obtained as a commercial APTT-reagent from Dade (Aguada, Puerto Rlco, USA). The commerclal reagent was diluted $1: 5$ with $0.05 \mathrm{M}$ Tris-HCl ( $\mathrm{pH} 7.35$ ) contalining $0.1 \mathrm{M} \mathrm{CaC1}{ }_{2}$, prewarmed for 10 minutes at $37^{\circ} \mathrm{C}$ and inixed before ure.

\section{Protelins}

Bovine prothrombin and factor $X$ were prepared as described by Lindhout et al (7). Bovine factor IX was prepared by the method of Fujlkawa et al (8). Bovine factor VII was kind1y supplled by Dr. C. Reutelingsperger.

\section{Commerclal reagents}

Human congential deflelent plasmas were obtained from Behring Institute (Weat Germany). Soybean trypsin Inhibitor (SBTI) was obtalned from Slgma (St. Louls, USA). The chromogentc substrate $\$ 2238$ was obtained from Kab1 vitru (Stockholm, Sweden). All other chemicals were of the highest grade commercially dvatlable. 
Measurement of clotting factor II, VII, IX and $\mathrm{X}$ activities in dicoumarol plasma

The activity levels of the clotting factors II, VII, IX and $x$ in dicoumarol plasma were quantitatively determined by a standard one-stage method according to the procedure of manufacturer (Behring Institute, West Germany).

Heasurement of thrombin generation in plasma

For the measurement of thrombin generation the procedure described by Hemker et al (9) was used. Brlefly, $240 \mu 1$ of plasma and $60 \mu l$ of buffer (Tr1s- HC1, $\mathrm{pH} 7.35$ ) were incubated for 4 winutes at $37^{\circ} \mathrm{C}$. Thrombin generation was triggered by the addition of $60 \mu \mathrm{\mu l}$ of $0.1 \mathrm{M} \mathrm{CaCl}_{2}$ solution containing a sultable trigger of coagulation. For activation of the extrinstc pathway the trigger consisted of thromboplastin (final dilution 1/240) and for activation of the intrinsic pathway Cephaloplastin (final dilution $1 / 30$ ) was used. At fixed time Intervals, $10 \mu l$ allquots of the incubation mixture were subsampled into a test tube containing 465 ul of buffer $(\operatorname{Tr} 1 \mathrm{~s}-\mathrm{HC1}, 0.1 \mathrm{M} \mathrm{NaC1}, 0.5 \%$ albumin, $0.02 \mathrm{M}$ EDTA, pH 7.9) and $25 \mu 1$ of S2238 (4 mM) at $37^{\circ} \mathrm{C}$. The subsampling tubes vere incubated for 2 minutes at $37^{\circ} \mathrm{C}$, and then the reaction was stopped by the addition of $300 \mu 1$ of concentrated acetic acid. The pipettes used for sampling and stopping the reaction were connected to an Apple Ile computer, programmed to record the moment of sampling and the moment of stopping the reaction. The optical density was read at 405 nm in a spectrophotometer (LKB-iJleraspec.). Prom the change in optical density and the time interval between manpling and stopplng the $\Delta O . D . / \mathrm{min}$ was automatically calculated *

\section{Measurement of the decay constant of endogenous thrombin}

Briefly, $120 \mu 1$ of plasma and $24 \mu 1$ of buffer (Tris-HCl, $\mathrm{pH} 7,35)$ were Incubated for 4 minutes at $37^{\circ} \mathrm{C}$. Thrombin generation was triggered by the addition of $30 \mathrm{ml}$ of thromboplastim. At the noment after a maximal thrombin formation, $6 \mu 1$ of Soybean Trypsin Inhibitor (SBTI, $10 \mathrm{mg} / \mathrm{ml}$ ) were added to the incubation ixture. At flxed lntervals after the addition of SBTI, 10 


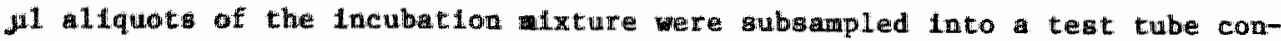
talning $\$ 2238$ ( 4 miM) and EDTA $(20 \mathrm{mM}$ ) by using the time recording plpette. The weasuring procedure was the same as that described for the measurement of thrombin generation (9).

The data obtalned from throbin amidolytic activity at the different time points $(C t)$ were fitted to the formula $C_{t}=C_{R}+C_{o} e^{-k t}$, which gives the level at the woment of SBTI addition $\left(C_{0}+C_{R}\right)$, the ateady end level $\left(C_{\mathbb{R}}\right)$ and the decay constant $(k)$. The parameters were deterwined by means of an ordlaris least aquares fit of the model to the data. The parameter values that inimize the sur of squared residuals were calculated using the Box-Kanemasu wodffication of Gaus" method (10). The IInear equations were solved by means of Haussholder transformatlons. The decay constant thus obtallaed is the of the $\alpha-{ }_{2}$ macroglobulin dependent decay constant ( $\left.k_{2}\right)$ and the ant thrombin III dependent decay constant $\left(k_{1}\right)(9)$.

\section{Qstimation of the prothrombin conversion velocity}

The prothrombim conversion velocity, l.e prothrombinase activity ( $\mathrm{nM}$ m $\mathrm{n}^{-1}$ ) was calculated by a computer, wing the thrombin generation and the experlmentally determined decay constant of endogenous thrombin. As described above, the decay constant of endogenous thrombin obtained is the sum of $k_{2}$ and $k_{1}$. The $k_{2}$ used is $0.232 \pm 0.004 \mathrm{~min}^{-1}(\mathrm{n}=25)$. For technlcal details aee ref. 9 .

RESULTS

Time course of thrombin generaclon and prothromblase formation in normal and dicoumarol plasmas

The levels of factor II, factor VII, factor IX and factor $\mathrm{X}$ activity in the pooled dicoumarol plasmare shown in table 1 . Figure 1 shows the time course of thromblit generation and prothrombinase formation in normal and dicoumarol plasmater triggering coagulation with thromboplastin. As can be seen, the Initial rate of thrombin formation and the waximal amount of thrombin generated were igniflcantly decreased in dicoumarol plasma compared to normal plasma. 


\section{TABLE I}

Levels of the clotting factor II, VII, IX

and $X$ activity in pooled dicoumarol plasma

\begin{tabular}{lcc} 
Factor & $\begin{array}{c}\text { Activity } \\
\%\end{array}$ & $\begin{array}{c}\text { Approximate Conc. } \\
\text { (nM) }\end{array}$ \\
\hline II & 20 & 300 \\
VII & 10 & 1 \\
IX & 40 & 30 \\
X & 20 & 35 \\
\hline
\end{tabular}

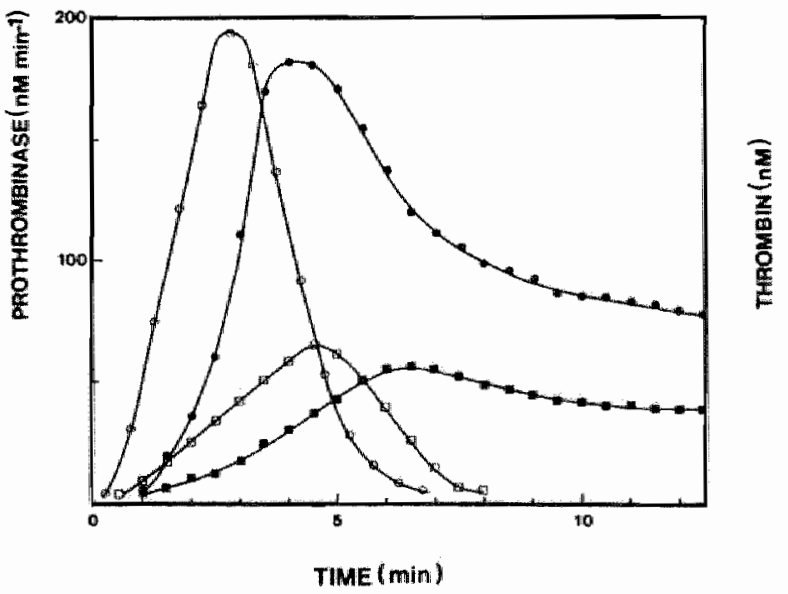

Fig. 1. Time course of the thrombin generation and prothrombinase formation in normal and dicoumarol plasmas after triggering coagulation with thromboplastin (final dilution $1 / 240$ ).

Thrombin In normal plasma

O-O Prothrombinase In nornal plasma
Thrombin in dicoumarol plasmain

0 Prothrombinase in normal plas
Thrombin in dicoumarol plasmat

$\square \longrightarrow$ Prothrombinase in dlcoumarol plasina 


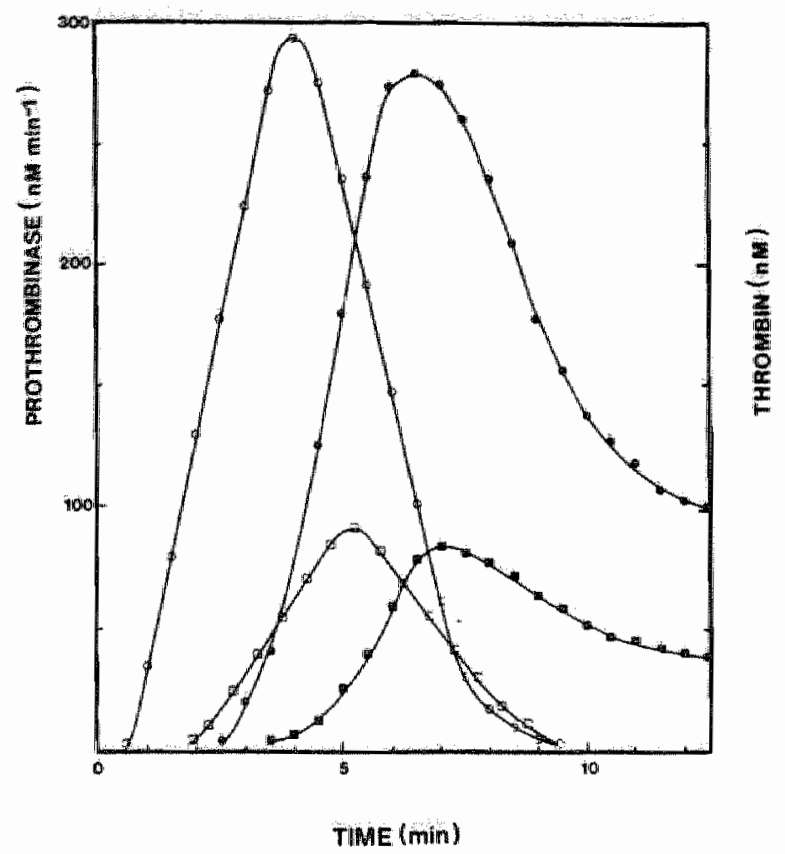

E1g. 2. Time course of the thrombin generation and the prothrowbinase formation in mormal and dicoumatol plasma after triggering coagulation with Cephaloplastin (final dilution $1 / 30$ ).

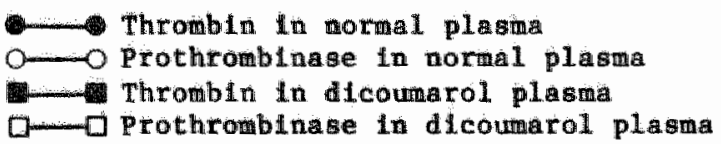

Figure 2 show the time course of thrombin generation and prothrombinase formation in normal and dicoumarol plasma after triggering coagulation with Cephaloplastin. The decrease in both the thromin generation and the prothrosinase formation were sinllar to those obtalned in thromboplastin triggered coagulation, but in addition, the lag time in the thrombin generation and prothrombin formation were significantiy prolionged in dicoumarol plasma compared to normal plasma. 
Effect of the addition of a various amounts of factor II, factor VII, factor IX and factor $X$ to dicoumarol plaswas on thrombingeneration and prothrombinase formation.

To determine which one among the four coagulation factors Influenced by dicoumarol drugs is mainly responsible for the decreases of thrombln generation and prothrombinase activity, we investigated the effect of the addition of increasing amounts of respectively factor II, factor VII, factor IX or factor $X$ to dicoumarol plasma. When studying the effects of factor II, factor VII and factor $X$, coagulation was triggered with thromboplastin and when studying the effect of factor IX coagulation was triggered with Cephaloplastin.

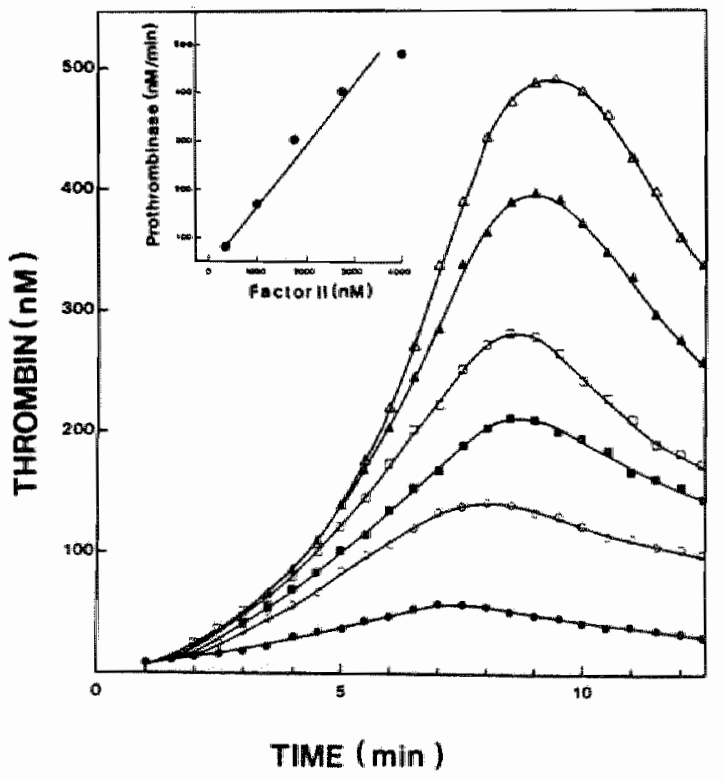

FIg. 3. Effect of the addition of various amounts of factor II to dicoumarol plasma on thrombin generation.

Coagulation was triggered with thromboplastin (final dilution $1 / 240$ ). The 1nset represents the maximal prothromblnase activity calculated from the thrombin generation curves. 
Plgure 3 shows the effect of the addition of lacreasing amounts of factor II thrombin to dicoumarol plasma on thrombin generation and pxothrombinase formation. As can be seen, both thrombin generation and prothromblasa formation linear1Iy Increased with the amounts of factor II added. In both cases the Increases were directy proportional to the concentration of factor II added to dicoumarol plasma. Theoretlcally we should expect sacuration phenomenon at high factor Ir levels. From fig. 3 (1nset) $1 t$ is clear that even $4 \mu M$ of factor II (more than a tuice the phys lologleal concentration) st111 is far from the saturating concentration. These observations indicate that the prothrombin converting capacity originally present in dicoumarol plasma 1 sufflcieat to catalyze the conversiton of wheh higher amounts of prothromin than that are present in dLcoumatol plasma. Flgure 4,5 and 6 show the effects of the addition of factor VII, factor $I X$ and factor $X$ to dicoumaral plasma on thrombin generation and prothromblnase formation. These figures show that neteher the thrombia generation nor the prothrombiname formation could be stimulated by the addition of the factors VII, IX and $X$.

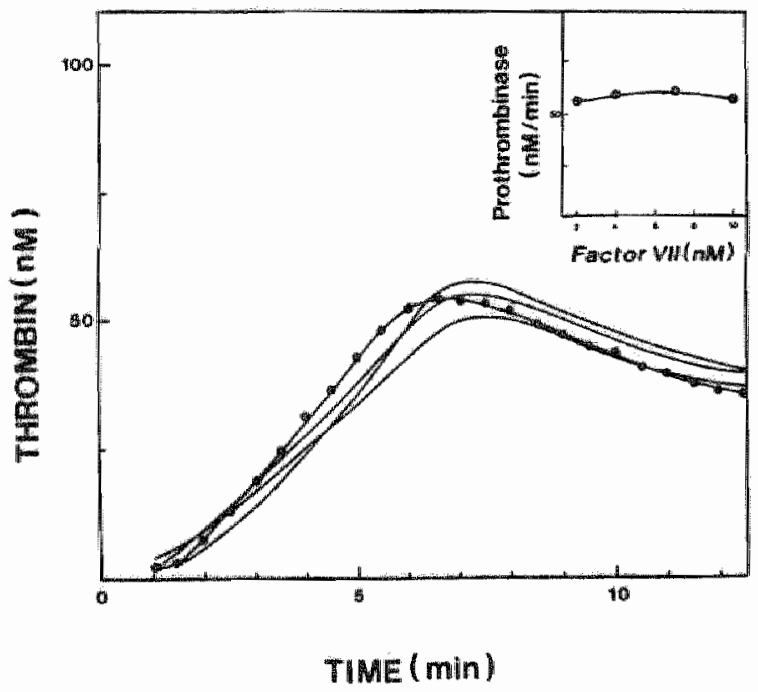

Fig. 4. Effect of the addition of vartous amounts of factor VII to dicoumarol plasina on thrombin generation.

Coagulation was triggered with thromboplastn (final dilution 1/240). The inset represents the maximal prothromblnase activity calcualted from the thromin gemeration curves. 


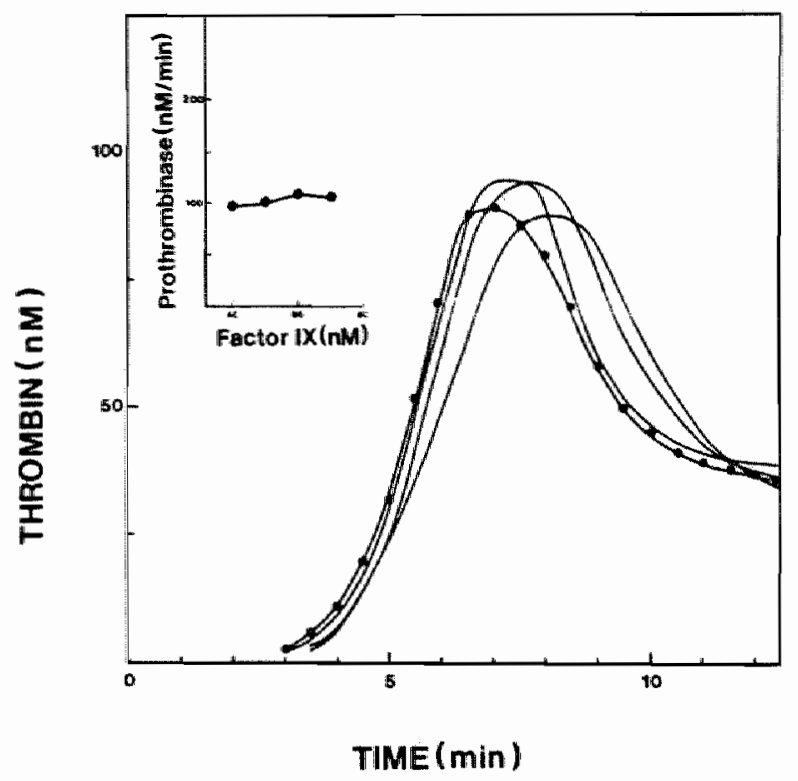

F18. 5. Bffect of the addition of varlous amounts of factor IX to dicoumarol plasma on thrombln generation. Coagulation was triggered with Cephaloplastin (final dilution 1/30). The inset represents the maximal prothrombinase activity calculated from the thrombin generation curves.

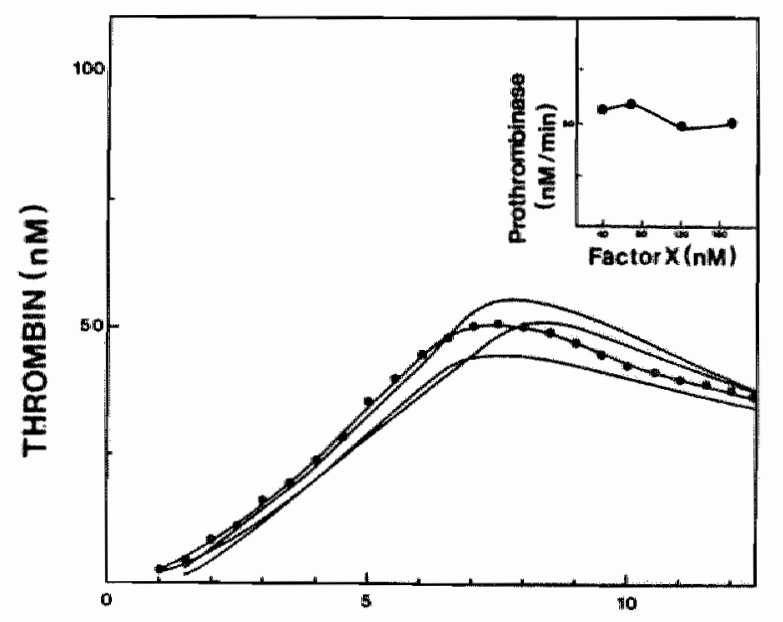

Fig. 6. Effect of the addition of various amounts of factor $X$ to dicoumarol plasma on thrombln generation. Coagulation was triggered with thromboplastin (final dilution $1 / 240$ ). The Inset represents the maximal prothrombinase activity calculated from the thrombin generation curves.

TIME $(\min )$ 
Effecta of the addition of varlous anounts of factor II, factor VII, factor 1X and factor $X$ to congenital defletent plasma on thrombin generation and prothrowblnase formation.

In order to obtalu an Inpression of the levels below which prothrombin and the factors VII, IX and $X$ start to have an influence on prothrombin converilon, we perorwed further experimemts in which the effect of the addition of a varlous amounts of the four vilamin $k$-dependent clotting factor to congenical deficlent plasmas was gtudled the results of these experiments are sumarized in figure 7.

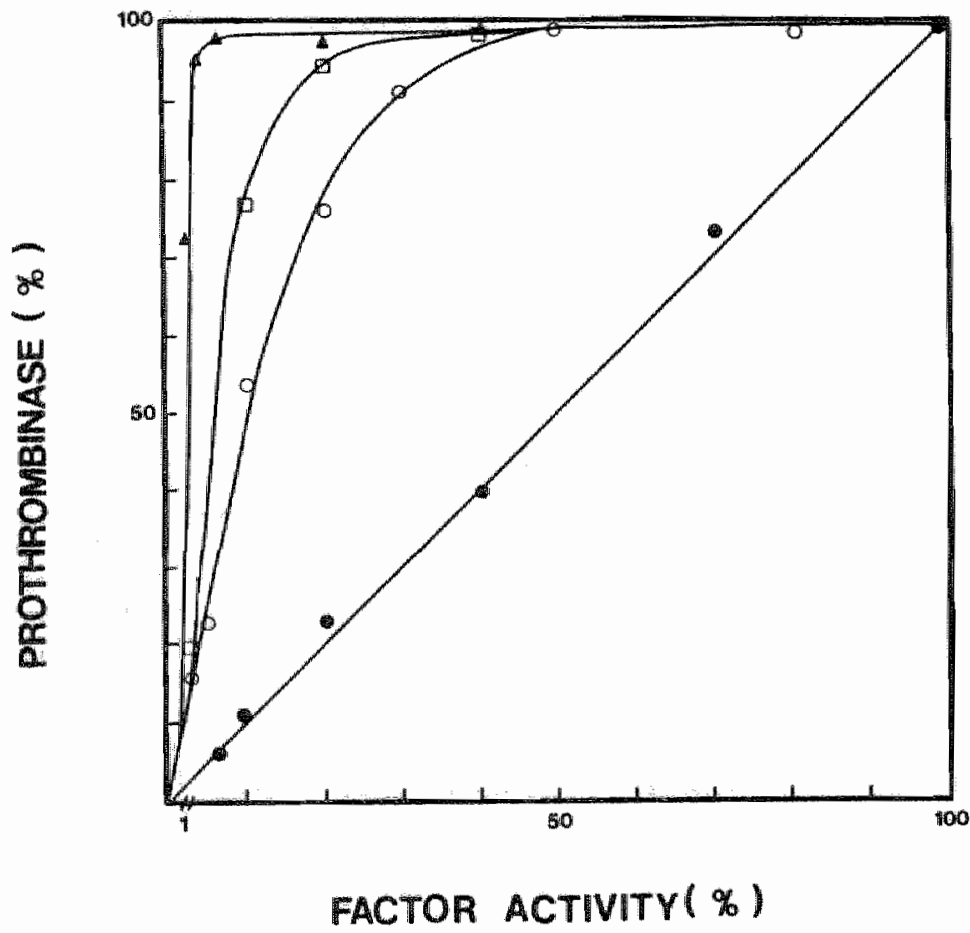

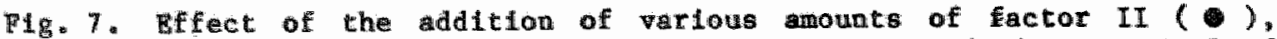
factor VII ( A), factor IX ( $(\mathrm{C})$ and factor $X(O)$ on maximal of prothromblnase activity formed in congenital deficlent plasmas. 
It can be clearly seen that the prothromblnase formation linearily increases with the amounts of factor II added to factor II deflctent plasma. The factors VII, IX and $X$ start to bave an effect on prothrombinase activity when the levels of factor VII, IX and $X$ are below $5 \%, 20 x$ and $40 \mathrm{x}$, respectively. Half maximal prothromblnsse activity is found roughly for factor VII at $1 \%$, for factor IX at $5 \%$ and for factor $X$ at $10 x$.

\section{DISCUSSION}

The hypocoagulability of dicoumarol plasma 1 s due to the diminution of the effective coagulation activity of the four vitamin $k$-dependent clotting factors, prothrombin, factor VII, factor $\mathbb{I X}$ and factor $X$. The underlying mechanism is that dicoumarol derivatives inhibit the carboxylation of certain glutamic acid resldues during the synthesis of precursors of the vitamin $k$-dependent clotting factors. The $y$-carboxyglutamic acld residues formed during this carboxylation process are involved in the binding of the vitamin $\mathrm{K}$-dependent clotting factors to phosphollpid surfaces via $\mathrm{Ca}^{2+}$ bridges (2). A diminution in the concentrations of the effective (ine. $\mathcal{Y}$-carboxylated) vitamin $\mathrm{k}$-dependent clotting factors, therefore, can be expected to Influence the formation of the multicomponent enzymatic complexes involved in the coagulation cascade. As a result of these events the thrombin generation will be reduced (Fig. 1 and $\mathrm{Fig}, 2$ ).

Due to the different half-11fe times of the vitamin K-dependent clotting factors, the effect of oral antlcoagulant drugs garta wth the reduction of the factor VII activity within 24 hours after administration of the drug, the reduction of the factors IX, $X$ and prothrombin follows within 72 hours (4). Since a reduction in the effective concentration of vitamin $K$-dependent clotting factor is more easily detected in the thromboplastin-dependent global clotting assays than In the contact activathon-dependent assay, oral anticoagulant therapy 1 s usually wonltored by the prothrombin time type tests. Therapeutic levels are defined by the extent to whlch the prothrombin time is prolonged. It is good to realize that oral anticoagulant therapy determile the effective concentration of three factors that influence the prothrombin time (prothrombin, factor VII 
and factor $\mathrm{x}$ ) and that one fixed clotting time (e.g. 30 seconds) can repregent an Haflute varlecy of combinations of concentrations of these the clotting factors (5). In the Intelal pertod of ord anticagulant therapy reduction of the factor $\mathrm{VI}$ activity way be expected to determine the prothrombin tme whle after a longer perlod af tome the effective rebponse 111 probably depend on the reduced factor and/or prothrombin actilty. The exact mechanlan of the developnent of the antithrombotic effect by dirinution of clatting factors la mknow. Clinical experience has emplrically teached ws to keep the plasma chromboplastin the at a certaln level 1 arder to provide protection agalnst thrombosis with a Holual riak of baenorrhagle complicatlons (5).

In an attempt to beter understand the relatve contribution of the d1fferent itamin $\mathrm{k}$-iependent clotting factors to the overall clotting activity, we fild weasured the effect on chrombin generation of the addition of purifled vitamin K-dependent clotting factor to dicounarol plasma. We found that only the prothrombin level orliginally present la the deoumarol plama deteralne the course of thrombla generation. The prothromblnase activity formed (about $20 \%$ of normal) in dicounarol plasma was sufficlent to catalyze the conversion of a normal amount of prothrombin (or even more) linto thrombin (P1g, 3). The addtion of the factors VII, IX or $\mathrm{X}$ to dleoumal plasma did not promote thrombia generatom; it nade no difference whether coagulation was triggered via the extrlasic or via the intrinstc pathway (F1g, 4,5,6). This implicates that, during the laltial and the Intemediate tages of oral antlcoagulant therapy, a prolonged in vtro prothrombla the caused by a reduced activity of the factors VII and * toes not adequately relect the thrombin generation potency of the pligina.

In order to flad out below which levell the witam kodependent cloteing factors start to have an effect on prothrombinase activity. we studied the effect of the addiclon of the purlfled vitam $R$-dependent clottlag factor to congendtal deflelent plaswas it was abow that the prothromblnase activity linemily Increases th the concentration of prothrombin and that the factors VI, IX and atat to have an effect on the prothrombinase activity then the concentrations were lower than $5 \%, 20$

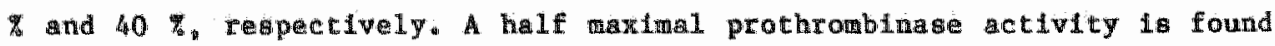
at bout 1\% (factor VIT), $5 \%$ (factor IX) and 10\% (factor X) (FIg. 7). It 
can be concluded that both the optimal factor $x$ converting activity (tenase) and the optimal prothrombin converting activity (prothrombinase) only require small amounts of the enzymes (factor $I X_{a}$ and factor $X_{a}$ ). Also, for triggering the thromboplastin-dependent pathway, only a small anount of factor VII is needed.

We conclude that the principal antithrombotic effect of oral anticoagulant therapy is achleved by influencing the effective prothrombin level. We therefore think that it may be interesting to use an assay that monltors the effective prothrombin level for the control of oral anticoagulant. therapy. 


\section{REPERENCES}

1. Vermeer, $C$. The role of vitamin $R$ in the post-translational modiflcation of proteins. In: Blood Coagulation. p. 87-101, 1986. Eds.: 2wal, R.F.A. Hand Henker H.C. Elsevier, Amaterdam

2. Stenflo, J., Sutte, JW. VItant K-dependent formation of

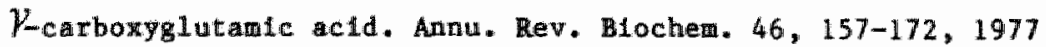

3. Hemker, H.C., Veltkamp, J.J. Nature of prothrombia blosgatbesis. prothrombinaenla in vitamin $\mathrm{K}$ deflclency. Nature, 589-590, 1963

4. Van Dam-MLeras, H.C.E., Henker H.C. Half-11fe tite and control frequency of vitamin K-dependent coagulation factors. Theoretical considerations on the place of factor VII in the control of oral antlcoagulation therapy, Haemostas1s, 13, 201-208, 1983

5. Hemker, H. C., Harulyak, R., Beguin, $S$. What heppens in the liver cell? In: Antlcoagulant therapy. p 13-23, 1986. Eds: 〈Bache〉, Basle, Swltzerland

6. van Dat-Mieras, M.C.E., Muller A.D., van Dleljen, G, Hemker, H.C.

In: Methods of enzymatic analysis. Enzyms 3: Peptidases, proteinase and their Inhibitors. Vol, V, 352-394, 1984, Verlag Chemle, Weinheim. Eds. WU Bergmeger

7. LIndhout, T., Govers-RIenslag, J.W.P., van de Waart, P., Rasing, J*, Hemker, H.C. Factor $\mathrm{V}_{\mathrm{a}}$-factor $\mathrm{x}_{\mathrm{a}}$ Interaction. Effects of phospholipid vesciles of varylig compsition. Blochemistry, 21,5494-5502, 1982

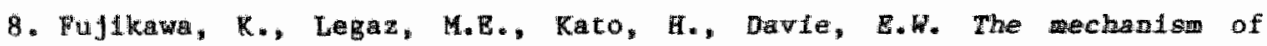
activation of bovlne factor IX (Christmas factor) by bowlne factor XI (activated plasma thromboplasin antecedent). Blochemistry. 13. $4508-4516,1974$

9. Henker, H.C., H11lems, G.N., Beguin, S. A computer asslsted nethod to obtain the prothrombin activation velocity in whole plasma independent of thrombin decay processes. Thromb. Haemogt. 56, 9-17, 1986

10. Hemker, H.C., WHIlems, G.K., BEguIn, S. Thrombinoscope, a personal computer program for the analysis of thrombln generation curves. Compur Blol. Med. (submitted). 
CHAPIER IV

SJAMP, A HEPARIN-LIKE MATERIAL FROM STICHOPUS JAPONICUS SELENRA: EFFECT ONTHE GENERATION OF THROMBIN ACTIVITY IN PLATELET POOR AND PLATELET RICR PLASMA

SUMMARY

Stlchopus faponlcus acldic mucopolysaccharide (SJAMP) is a heparin-1ike material that can be isolated from stichopus japonicus selenka (sea cucumber). In Thls chapter the influence of SJAMP on the generation of thrombin activity in platelet poor and platelet rich plasma is described.

The main effect of SJAMP is to inhibit thrombin. Thil effect of SJAMP is about sixteen-fold weaker than that of 4 th international standard heparin on a welght basis. When the experiments are carried out in platelet poor plasma after triggering coagulation th thromboplastin, Inhibition of the amount of thrombln formed can be explained by the acceleration of thrombin decay achleved by SJAMP. When coagulation in platelet poor plasma 15 triggered with Cephaloplastin an additional effect of SJAMP 1 seen; $1 \mathrm{t}$ fncreases the lag time in the thrombin generation process. This phenomenon could be explained by Inhibltion of the feedback activation of factor VIII by thrombin. In these aspects SJAMP acts exactly like standard hepartin.

When the effect of SJMMP is tudied in platelet rich plasma after triggering coagulation with trace amounts of thromboplastin alight stimulation of thrombin generation is observed at Low SJAMP concentrations, while at higher SJAMP concentrations inhibition of the maximal amount of thrombin formed and an increase In the lag time of the thrombln generation process 1 s observed. This Indicates that the inhibitory effect of SJAHP on 
throwbin activity, unilke that of heparin, can not be neutrallzed by platelet factor 4. The increase in lag tume of the thromin generation process way be explained by lahibition of the feedback activation of factor VII and by inhibition of the thromblm-Induced platelet stimiation.

INTRODUCTTON

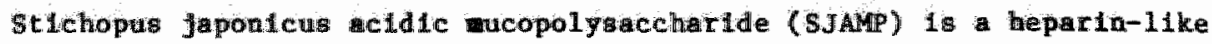
materlal that can be lsolated from stlchopus Japontcus belenka (a sea cucunber).

Structure analysis shows that it contains -acetylgalactosane, glucuronic actd, fucose and sulphate in the approxlmate ratio of $1: 1: 1: 4$, respectively (1). The wolecular welght of SJAMP 1 s about $30,000-50,000$ Dalton. Some physical properties of SJAMP, 11ke for Instance the metachromatic intensity and the lectrophorette behaviour, are imllar to those of heparin (1). The mechanism of action of SJAMP wh respect to its anticoagulant activity is st111 unknown, but remarkable differences between SJAMP and heparin have been deacribed (2) (see below).

A crude preparation of SJAMp was previously used in china as a traditlonal drug for the treatment of patients with gastrlc carcinoma. It was generally considered to be a beneficlal complementary drug for these patients because it could mitigate the symptoms and reduce the pain. However, administration of large dose, or of a low dose for a long tue, wa asoclated wh bleeding symptoms in some patients.

These phenomen have recelved wach attention in the past few years $(1-3)$. It wa concluded that the effect of SJAMP on blood coagulation is due to lts action on thrombin and that the ade of action of SJAM 18 different frow that of heparin in thet it is independet upon antithromiti III. These conclustons rere bssed on the observation that the presence of SJAMP caubes prolongation of the thrombin time lin both normal and artificlal antithrombIn III-deflelent plaswas.

Studies in platelet rich plasma revealed that the lahibltory action of SJAMp cowards throwbln was not influenced by a change in the amount of platelet present (2). The authors therefore concluded that SJAMP, In contrast to hepartin, could not be neutrallied by platelet factor 4 rellased during activation of the placelets. 
It was also observed that SJAMP induces the aggregation of human and rabbit platelets in vitro (2). The platelet aggregation curve induced by SJAMP is simllar to that Induced by ADP. As SJAMP falled to Induce platelet aggregation In platelet rich plasma prepared from $\mathrm{Na}_{2}$-EDTA treated blood, It was concluded that the induction of platelet aggregation by SJAMP is $\mathrm{Ca}^{2+}$-dependent.

Finally it was observed that administration of S.JAM can cause a reduction in the amount of clrculating platelets in the blood of experimental antmals (2). This reduction in the amount of circulating platelets can probably be explained by the aggregating effect of SJAMp om blood platelets. This aggregating effect could not be influenced by aspirin and therefore seems to be independent of the arachidonic acid metabolism (2).

In view of the observations clted in this intraduction thought it worthwile to study the Influence of SJAMP on the generation of thrombin activity in plasma. In this chapter we report the results of these Investigations.

MATERIALS AND METHODS

\section{Platelet free plasma}

Blood from healthy donors was collected in trisodium cltrate ( 9 volumes of blood to 1 volume of $0.13 \mathrm{H}$ trisodtum cltrate) and centrifugated for 15 minutes at $3000 \mathrm{x} g$ at $15^{\circ} \mathrm{C}$. Subsequently the platelet poor plasma obtaltaed was centrifugated for $\mathbb{d}$ hour at $23000 \times \mathrm{g}$ at $4{ }^{\circ} \mathrm{C}$. "The platelet free plasma was stored at $-80^{\circ} \mathrm{C}$.

\section{Platelet rich plasma}

Platelet rich plasma was prepared by centrifugation of freahly drawn citrated blood for 10 minutes at $900 \times \mathrm{g}$ at $15^{\circ} \mathrm{C}$ and was wed within 2 hours. 
Thromboplasten

Human brald thromboplastin was prepared by a modification of the method of Owen and Aas (4). The preparation obtalmed was homogenlied in a potter Q Welfew homogeniser for 3 minutes, centrifugated at $2000 x \mathrm{~g}$ for 15 witutes and stored in 1 mil allquots at $-20{ }^{\circ} \mathrm{C}$. Prlor to use the preparat1on was thawed, d1luted $1: 40$ with $0.05 \mathrm{M} \operatorname{Tr} 1 \mathrm{~s}-\mathrm{BCl}$ (pH 7.35) contalning $0.14 \mathrm{CaCl}_{2}$ and prewarned at $37{ }^{\circ} \mathrm{C}$ for 1 hour. When normal plasma was incubated wh this thromboplastin dilution under the same experluental conditions as used in the thrombln generation experiments the clotting time was 80 seconds.

\section{Cephaloplastun}

Cephaloplastin was obtalned as a commerclal APTT-reagent from Dade (Aguada, puerto Rico, USA). The comerclal reagent was diluted 1 : 5 with $0.05 \mathrm{M}$ Tris-HCl ( $\mathrm{pH} 7.35$ ) contalning $0.1 \mathrm{M} \mathrm{CaCl}_{2}$, prewarmed for 10 minutes at $37{ }^{\circ} \mathrm{C}$ and mixed before use.

Stichopus japonicus actdic mucopolysaccharlde (SJAMP)

SJAMP was kindiy supplled by Dr. Jla-Zeng L1, Institute of Hematology, rianjin. China. The compound was isolated and purified in the Blachemical Laboratory of Tiajln Medical and Pharmacological Institute, China.

Hepar1n

4th linternational atandard heparin was obtalned from the National Iastltute for Blologfcal Standards and Control (NIBSC).

\section{Buffers}

Buffer A: $0.05 \mathrm{MTeL}-\mathrm{HCl}, 0.1 \mathrm{M} \mathrm{NaCl}$ (pH 7.35)

Buffer B: $0.05 \mathrm{M} \operatorname{Tr} 1 \mathrm{~s}-\mathrm{HCl}, 0.1 \mathrm{M} \mathrm{NaCl}, 0.5 \mathrm{a}$ abumin, $0.02 \mathrm{M} \mathrm{EDTA}$ (pA 7.9 ) 
Commercla1 reagents

The chromogenlc substrate $\$ 2238$ was obtalned from Rabl Vitrum (Stockholm, Sweden). Soybean trypsin inhibitor was obtained from sigma (St. Louls, USA). All other chentcals were of the highest grade comercially avallable.

Measurements of thrombin generation in plasma

For the measurement of thrombln generation the procedure described by Hemker et al (5) was used. To $240 \mu 1$ of a plasma preparation, $60 \mu 1$ of buffer A contalning the compound to be tested was added. The test tube was incubated for 5 minutes at $37^{\circ} \mathrm{C}$. Thrombin generation was triggered by the addition of $60 \mu 1$ of a $0.1 \mathrm{M} \mathrm{CaCl}_{2}$ solution containing a sultable trigger of coagulation. For activation of the extrinsic pathway the trigger consisted of thromboplastin and for activation of the intrinstc pathway Cephaloplastin was used. At fixed time intervals, $10 \mu 1$ allquots of the lincubation milxture were subsampled tato tubes contalaing $465 \mu \mathrm{l}$ of buffer B and $25 \mathrm{w1}$ of $\$ 2238(4 \mathrm{mM})$ at $37^{\circ} \mathrm{C}$. The subsampling tubes re incubated for 2 minutes at $37^{\circ} \mathrm{C}$, and then the reaction was stopped by the addition of 300 m concentrated acetic actd. The pipettes used for sampling and stopplng the reaction were connected to an Apple IIe computer. A program was developed that allowed automatic registration of the noment of subsampling and the moment of stopping the reaction. The optical density ras read at $405 \mathrm{~nm}$ in apectrophotometer (LKB-U1trospec). Prom the change In optical denstty and the time interval between subsampling and stopping the $\Delta 0 . \mathrm{D} . / \mathrm{min}$ was automatically calculated.

Measurement of the decay constant of endogenous thrombin

Briefly, $120 \mathrm{jl}$ of plama and $24 \mathrm{jl}$ of buffer A vere lacubated for 5 minutes at $37{ }^{\circ} \mathrm{C}$. Thrombin generation was trilggered by the addition of 30 jl of thromboplastin solution or Cephaloplastin solution. At the mowent after waximal thrombin formation, $6 \mu l$ of soybean trypsin imhibitor solution (SBTI, $10 \mathrm{mg} / \mathrm{ml}$ ) and $10 \mu \mathrm{j}$ of a solution of the compound to be tested, taken up in the same pipette, were added to the reaction wixture. 
At wortest possible intervalis after addition of SBTI and the compound to be tested, $10 \mathrm{jl}$ ilquots of the Incubation mixture were subsampled into tubes contalning $\$ 2238$ (4mM and EDTA (20 mM) by using the time recording pipette. The measuring procedure was the awe as that described for the measurewent of thrombin generation.

The data obtained from thrombin andolytic activity at the different time polate $(C t)$ were fitted to the formula $C_{t}=C_{R}+C_{0} e^{-k t}$, which gives the level at the noment of SBT addition $\left(C_{R}+C_{0}\right)$, the steady end level $\left(C_{R}\right)$ and the decay constant $(k)$. The parameters were determined by means of an ordinary least squtsares fit of the model to the data. The parameter values that winlmize the sum of squared residuals were calculated using the Box-Kanemasu wodflcation of Gauss' method (6). The 11near equations were solved by means of Haussholder transformations. The decay constant thus obtalned is the of the $\alpha_{2}$-macroglobulin dependent decay constant $\left(k_{2}\right)$ and the amtithrombin III dependent decay constant (k $)(5)$.

\section{Betimation of the prothrombin conversion velocity}

The prothrombin conversion veloclty (prothrombinase $n M$ min $^{-1}$ ) was calculated by a computer using the thrombin generation data and the expertmentally deternined decay constant of endogenous thrombin. As described above, the decay constant of endogenous thrombin obtained is the sum of $k_{2}$ and $k_{1}$. The $k_{2}$ used $1 \mathrm{~s} 0.232 \pm 0,004 \min ^{-1}(\mathrm{n}=25)$. For technical detall see ref. 5 .

RESULTS

Influence of SJAMP on the decay of endogenous thrombin in plagma

Before tudying the Influence of SJAMP on the decay of endogenous thrombia in plasma we fist determined the time dependency of thrombin generation lin plasma without the addition SJAMP or heparin (FIg. 1). This enabled us to design the decay-experimentis in such a way that the prothrombinase lahibitor SBT was added jubt after the maximu 10 the thrombin activity versug the curve. In the thrombin decay measurenents sBTI and 
SJAMP were simultaneousiy added to the Incubation ixture five winutes after starting the coagulation. The amount of SBTI used was shown to stop the prothrombinase activity completely and not to influence the chrombin activity (5).

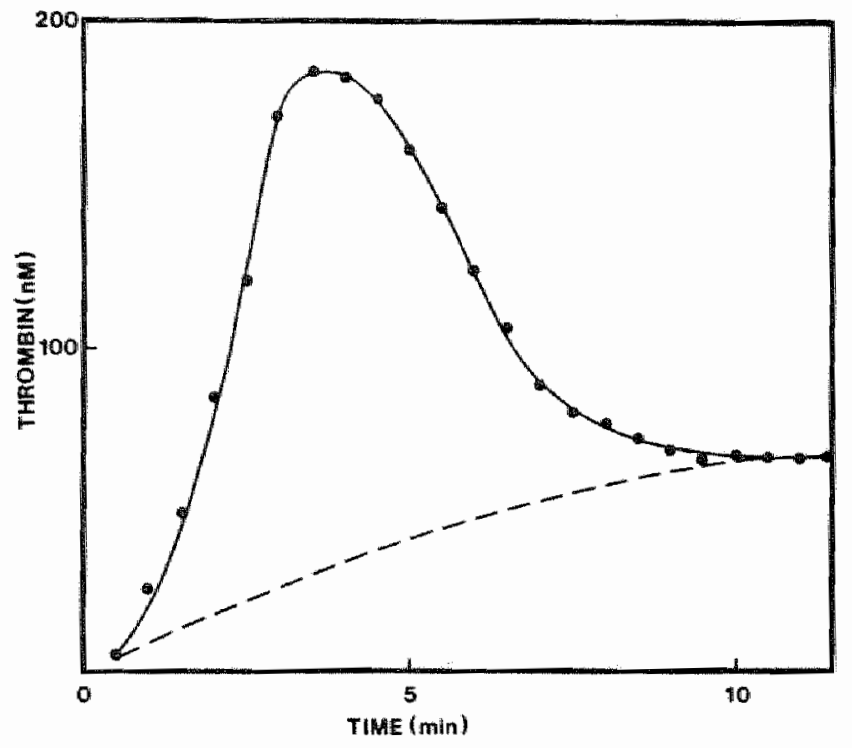

Flg. I Amldalytic activity of thrombin 1 plasmas a function of time. Coagulation was triggered with thromboplastin. The broken line represents the level of the $\alpha_{2}$ macroglobulin-thrombin complex. For technical deta11s gee the section Materials and Methods.

The effect of SJAMP on the decay of endogenous thrombin was compured to that of the tandard heparin under the same experimental conditions. The results are shown in flgure 2 . It can been that for both compounds the decay constant increases practically limearily with the concentration of the polysaccharlde. From a comparison of the slopes of the 11 nes it can be concluded that, on a weight basls, the effect of SJAMP on thrombin decay $1 \mathrm{~s}$ sixteen-fold weaker than that of heparin. 


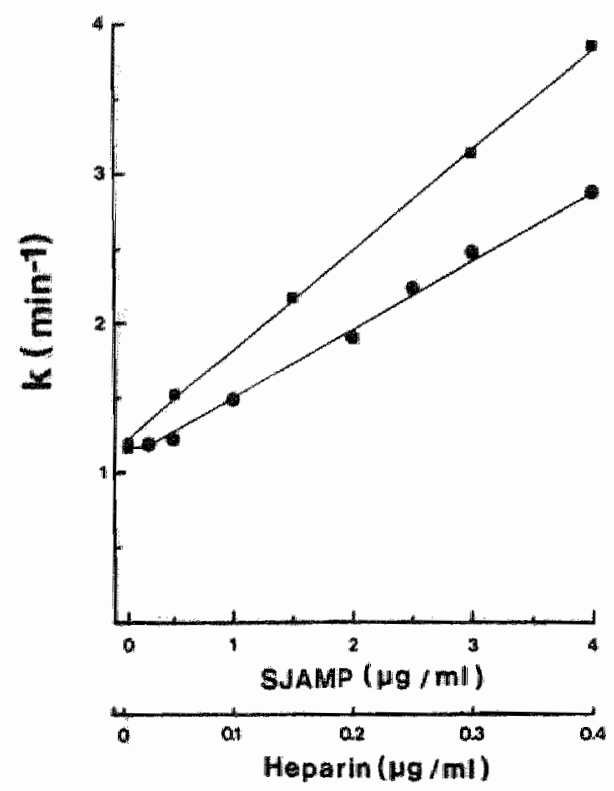

$\mathrm{Fig} .2$ The Influence of SJAMP ( ) and heparin ( $)$ on the decay constant of thrombli in plasma.

For each concentration of SJAMP or heparin the experiments were carried out at least three times. For technical detalls see the section Materials and Methods.

Effect of SJAMP on generation of thrombin activity and prothrombinase activity after triggertng coagulation with thrombaplastin

To tody the effect of SJAMP on thromblin generation and prothromblnase activty in the extrinalc pathway, SJAMP was added to platelet poor plasma and the coagulation tras trgered with thromboplastin (final thromboplastin dilution in the reaction fxture was 1 : 240), then thrombin generation was measured in time and prothromblnase activity was calculated. The results are hown in figure 3. It can be seen that in the presence of lacreasing amounts of SJAMP both the veloctty of thrombin formation and the waximal anount of thrombin formed were decreased. In the concentration range tested there was no effect of SJAMP on the Imitial lag time in time course of thrombin generation. 


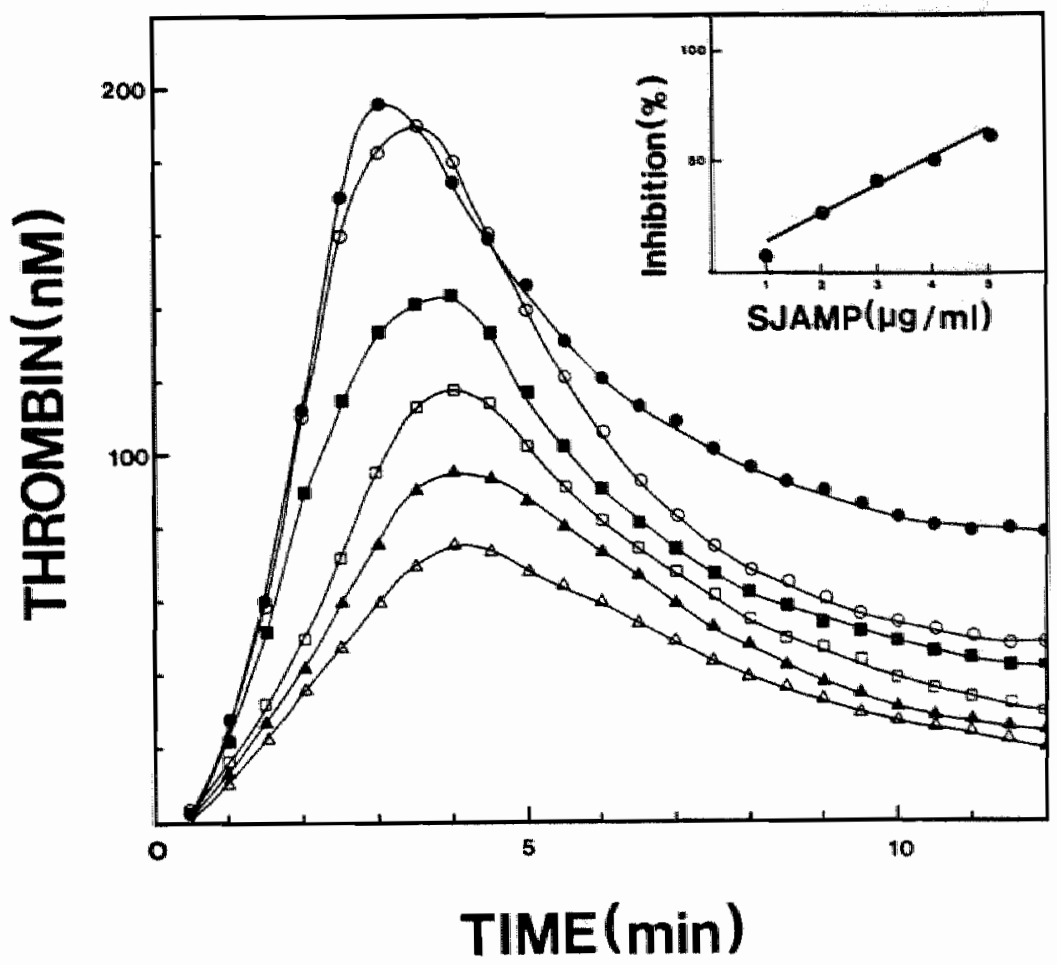

Fig. 3 The influence of SJAMP on the generation of thrombin activity via the extrinsic pathway in platelet poor plasma.

The 1nset representis the relationship between the maximal amount of thrombin formed and the SJAMP concentration.
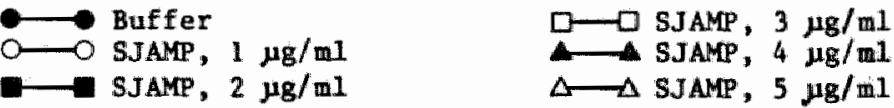

When the thrombin generation data were processed by computer to obtaln the prothrombinase activity, the curves shown in figure 4 were obtalned. It can be seen from figure 4 that SJAM does not have a algnificant lnfluence on prothrombinase activity in the concentration ranges tested. From this observation we conclude that SJAMP Inhibits the thrombin generation via the extrinsic pathway only by 1 ts influence on thrombin activity and not by influencing prothromblnase activity. 


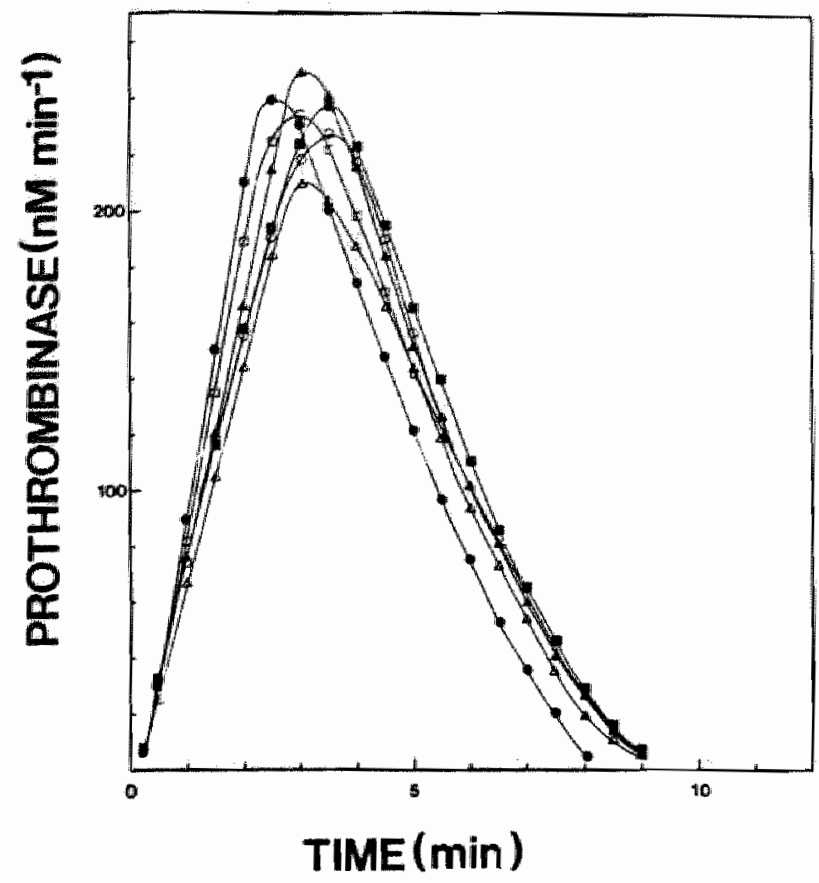

Fig. 4 The Influence of SJAMP on the prothroabinase formation vila the extrinsic pathway in platelet poor plasma.

The prothrombinase activity was obtained by computer processing of the thrombin generation curves shown in figure 3 . For technical detalls see the section Materials and Methods.

$\rightarrow$ Buffer

O SJAMP, $1 \mathrm{\mu g} / \mathrm{m} 1$

-O SJAMP, $2 \mu \mathrm{\mu g} / \mathrm{m}$ $\square-\square$ SIAMP, $3 \mu \mathrm{g} / \mathrm{mI}$

SJAMP, $4 \mu \mathrm{g} / \mathrm{mi}$

SJAMP, $5 \mu \mathrm{m} / \mathrm{mL}$

Ef fect of SJAMP on generation of thrombin activity and prothromblnase activity after triggering the coagulation with Cephaloplastin

In order to study the effect of SJAMP on thrombin generation and prothrowbinase activy in the Intringle coagulation pathway, Cephaloplastin was used to trigger coagulation. The generation of thrombla activity in platelet poor plasma contalning vartous amounts of SJAMP is shown in figure 5. 


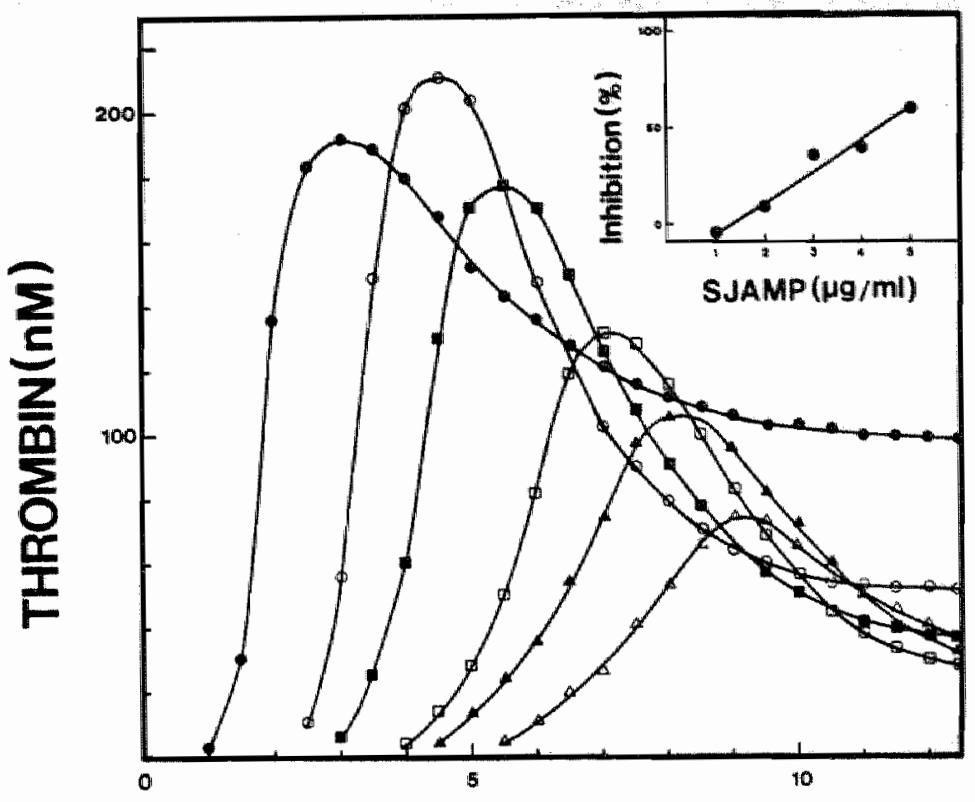

\section{TIME(min)}

Fig. 5 The Influence of SJAMP on the generation of thrombin activity via the intrinsic pathway in platelet poor plasma.

The inset represents the relationship between the maximal amount of thrombin formed and the SJAMP concentration.
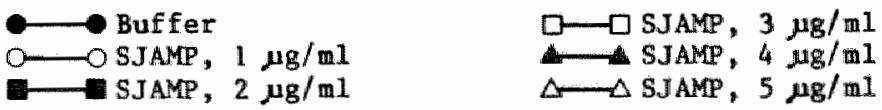

It is clear from this figure that, except at the lowest concentration tested ( $1 \mu \mathrm{g} / \mathrm{m} 1$ ), SJAMP caused an Inhibltion of thrombin generation not only reducing the waximal amount of thrombin formed, but also increasing the initial lag time in the time course of thrombin generation and that both effects were dose-dependent. A striking phenomenon was that at a low SJAMP concentration $(1 \mu \mathrm{g} / \mathrm{ml})$ the maximal amount of thrombin generated was slightly increased. However, after maximal thrombin formation, SJAMP accelerated the decay of thrombin activity at all concentrations tested. These results suggest that the predominant effect of SJAMP on thrombin 
generation 1 the inhibition of throwbin activity. When, however, the thrombla generation data were procesed by the computer 1 ato prothrombinase data (figure 6) 1t turned out that the prothromblnase activity generated 1a the Intriasic pathway was stimulated by SJAMP in a dose-dependent way.

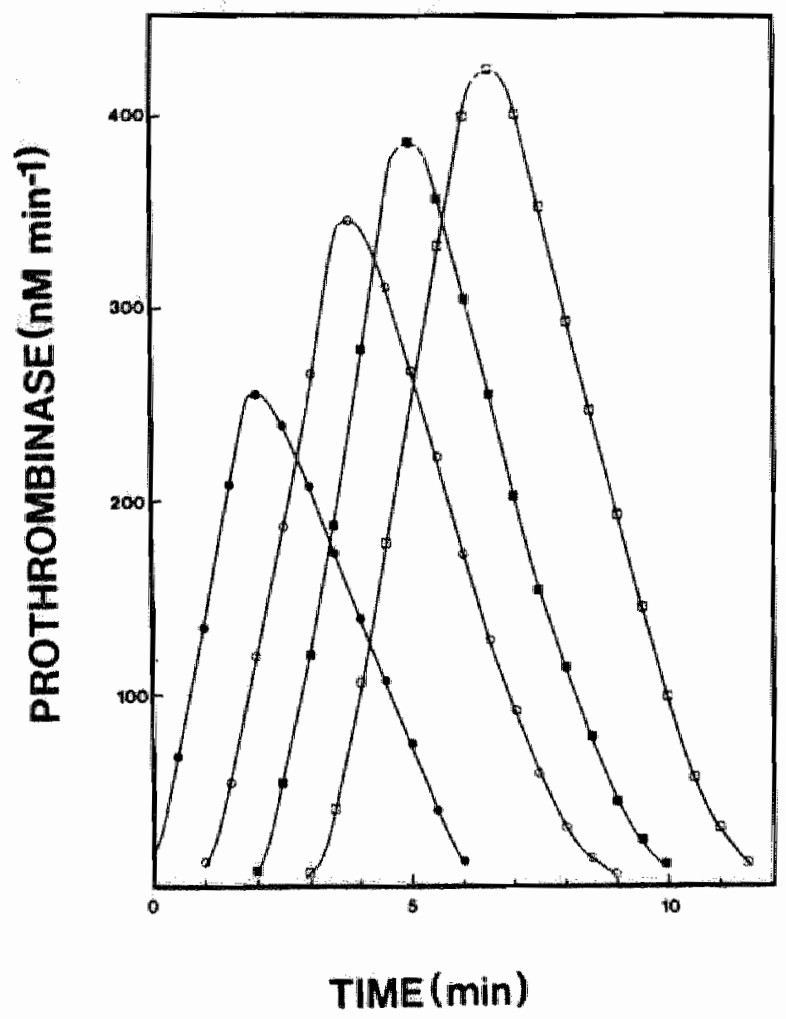

18. 6 The Influence of SJAMP on the prothrombinase fomation via the Intrinsic pathway.

The prothrombinase activity was obtained by computer processing of the thrombla generation curves shown in figure 5. For technical detalls see the section Materials and Methods.

Buffer

SJAMP, $2 \mu \mathrm{g} / \mathrm{ml}$

0 SJAMP, $1 \mu \mathrm{gg} / \mathrm{ml}$ 
Effect of SJAMP on the generation of thrombin activity induced by the combined effect of thromboplastin and thrombocytes

Low concentrations of human thromboplastin that show no effect in platelet poor plasma cause algniflcant thrombin generation in platelet rich plasma (7). Obviously, this effect is due to the cooperative effect of thromboplastin and thrombocytes in thrombin generation. The conditions mimicked in these in vitro experlments probably have a closer resemblance to the in vito situations than the "classical" in vitro coagulation assays.

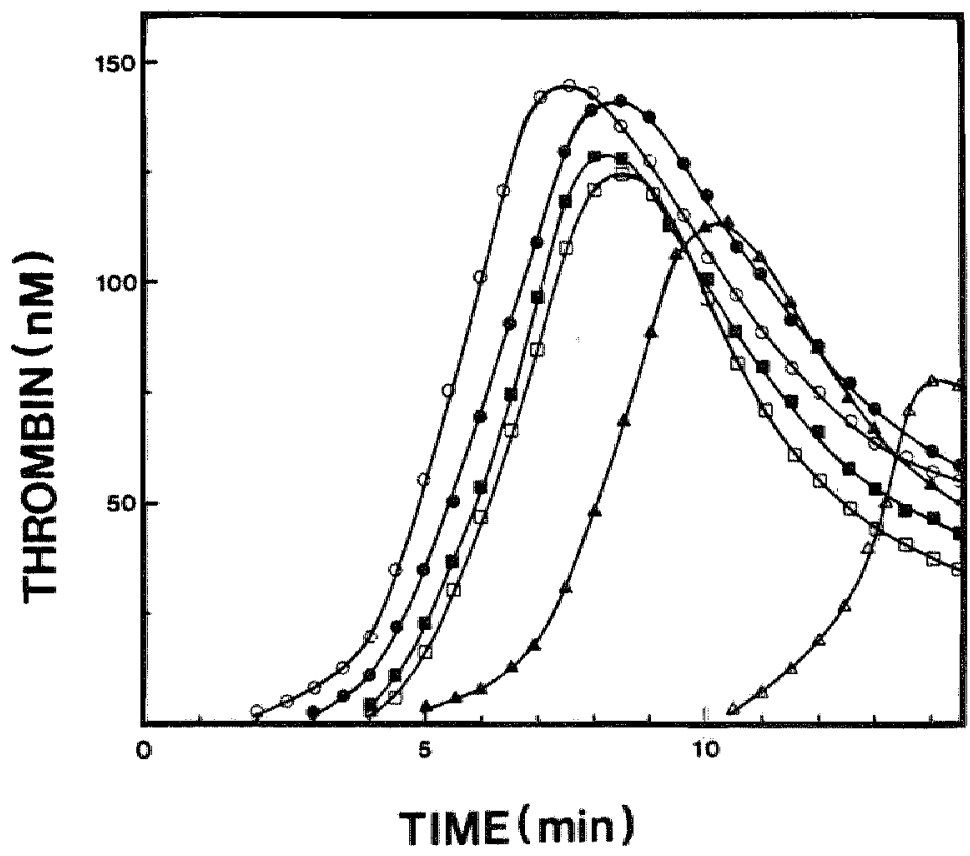

F1g. 7 The Influence of SJAMP on the generation of thrombin activity in platelet rich plasma.

The coagulation was triggered with a trace amount of thromboplastin (fimal concentration $1: 2400$ ).

Buffer

0 SJAMP, $1 \mu \mathrm{g} / \mathrm{m} 1$

— S.JAMP, $2 \mathrm{jg} / \mathrm{ml}$

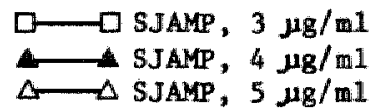


In our experiments thromboplastin solution wiluted wh $0.1 \mathrm{M} \mathrm{CaCl}$, alution (final thromboplastin dilution in the reaction mixture 1:2400) was chosen to trigger thrombin generation in platelet rich plasma $(300,000$ platelets/jl). The generation of thrombln activity in platelet rich"plasma contalning virlous amounts of SJAMP 18 shown in figure 7. At a low concencration of SIAMP $(1 \mu \mathrm{g} / \mathrm{mI})$ there was a slight stimulation of thrombin generation. While th higher concentrations of SJAMP there was a clear reduction in the maximal amount of thrombin formed. Once the maximal amount of thrombin forwed, however, the decay of thrombin activity was accelerated by SJAMP at all concentrations tested. Furthermore, at concentrations greater than $2 \mu g / m 1$ SJAMP also increased the inltal lag time in the time course of thrombin generation.

\section{DISCOSSION}

The administration of heparin for the treatment of a varlety of acute thrombotic disorders has been used in clinicall practice for about 50 years. The treatment is hampered however by the narrow "therapeutic window" 1imited by 1 nefflclency on the one side and bleeding on the other. Moreover, some patients develop thrombopeny and thrombotic complications in association with heparin therapy. These clinical findings have greatiy stimulated the Interest in compounds related to heparin which are reported to possess a greater antithrombotlc effectiveness while producing less hemorthag Ic complications than commerclal heparin and that are therefore gupposed to have a wider therapeutic window. Studies on low molecular welght derivative of comerclal hepartn, on heparimolds, which are naturally occurring mucopolysaccharldes chealcally distinct from heparia, and on a sythetic ollgosaccharlde sequence have recelved increasing atcention in the 11terature $(8-22)$. This encouraged us to study the effect of SIAMP on the generation of thrombin lin plasma.

SJAMP accelerated the decay of endogenous thrombin in platelet poor plasma. The rate constant of thrombln decay lacreased IInearly with the concentration of SJAMP $(0-4 \mathrm{jg} / \mathrm{ml})$ added to the plasma $(\mathrm{f} 1 \mathrm{~g} .2)$. When the effect of SJAMP on the decay of thrombin activity was compared with that of internat fonal standard heparin it was observed that, on a welght basis, 
the Inhibitory effect of SJAMP was about sixteen-fold weaker than that of standard heparia.

The effect of SJAMP on thrombin generation in platelet poor plasina after triggering coagulation with thromboplastin, $1 . e$. coagulation via the extrinsic pathway, can be explained by its inhibitory effect towards thrombin (Fig. 3,4). SJAMP had no influence on the inttial lag time of thrombin generation via the extrinsic pathway. We concluded that, in this experimental system, SJAMP mainly influences thrombla generation by $1 \mathrm{~s}$. Inhibitory effect on thrombin activity. This conclusion is supported by the results presented in figure 4 where the absence of an effect of SJAMP on prothrombinase activity in the extrinsle system is shown.

When the effect of SJAMP on thrombin generation in platelet poor plasma was studied after triggering coagulation fith Cephaloplastin, 1.e. coagulation via the intrinsic pathway (F1g. 5), SJAMP again accelerated the decay of thrombin activity at all concentrations tested $(0-5 \mu \mathrm{g} / \mathrm{ml})$ but it also caused a significant increase in the inltial lag time of the thrombin generation process. At a relatively low concentration ( $1 \mathrm{jg} / \mathrm{ml})$ SJAMP caused a slight increase in the maximal amount of thrombin activity formed; at higher concentratlons the maximal amount of thrombin formed was decreased.

From the results described above we concluded that the influence of SJAMP on thrombin generation via the intrinsic pathway is diferent from its influence on thrombin generation via the extrinstc pathway. It must be kept in mind, however, that in in vilo situation the intrinsic and extrinsic pathway may be 1 inked (see also chapter 2). As the find atep lin both the intriasic and the extrinalc pathway is the actlvation of prothrombin by the prothromblnase complex, the difference ust be caused by the Influence of SJAMP on preceeding step(s) of the pathway(s). The effect of SJAMP on the inftial lag time of thrombin generation via the intrinsic pathway may be explalned by 1 ts indirect effect on factor VIII activation. Thrombin activates factor VIII and factor VIII 1 s constituent of the factor $X$ activating complex (tenase complex) in the intrinsic pathway. Therefore, the lag time in the thrombin gemeration process all depend on the velocity of factor VIII activation by thrombin. This positive feedback reaction of thrombin can be expected to be lmbiblted by a thrombin scavenger such as SJAMP. To our surprise, SJAMP not only lncreaged the lag 
time in the thromin generation process after triggering coagulation with Cephaloplastit, it also stimulated the forwation of prothrombinase activity val the Intrinelc pathway in a dose dependent way. This concluston can be drawn from flgure $61 \mathrm{t}$ whlch the generation of prothrombinase activity at different SJAMP concentrations $1 \mathrm{~s}$ given. This stimulatory influence on the prothrowbinase activity wight explain the silght increase in the maximal amount of thrombin formed seen at low concentrations of SJAMP. At the moment have no explanation for the enhanclag effect of SJAM on the formation of prothromblnase activity wia the Intrinsic pathway. It must be stressed, however, that this stimulation of prothromblnase formation by increasing amounts of SJAMP did not result in the formation of higher anount of thromblin activity (fig. 5); the maxima in the thrombin generation curves decreased with increaging SJAMP concentrations. Therefore we feel that we must conclude that, also in the Intrinsic pathway, SJAMP acts as an anticoagulant by linhbiting thrombin activity.

When the effect of SJAMP on thrombin generation was gtudied in platelet rich plasma after triggering coagulation with trace amounts of thromboplastin, results similar to those obtalned in platelet poor plasma after triggering wth Cephaloplastin were observed. SJAMP reduces the maximal amount of thrombln formed and increases the inltial lag time at concentrations greater than $2 \mathrm{\mu g} / \mathrm{m}$. . This effect of SJAMP is essentally different from that of conventional hepartin. Under the same experimental conditions, hepartn only Increases the lag time th the process of thrombin generation but does not reduce the maximal amount of thrombin activity that 1 flnally formed (7). This effect of hepartin can be explained by 1 ts neutrallzation by platelet factor 4 released from the actlvated plateleta. The thrombin Inhibition by SJAMP in platelet rich plasma is not neutra11zed, In contrast to that of heperin. Increasing amounts of SJAMp cause an Increage in the decay of endogenous thrombin activity. This suggesto that SJAMP is not nevtrallzed by platelet factor 4, which lmplicates that after adminditration in vivo SJAMP might be more efficient than standard heparin.

The geacration of thrombin activity in platelet rich plasma after triggerling coagulation with small anounts of thromboplastin has been explained by the cooperative ffect of thromboplastin and platelets (7). Inhibition of thrombin by the speciftc thrombin inhlbitor hirudin increases the lag time of throwbin generation and small amounts of thrombin decrease it. 
Trace amounts of thrombin are supposed to stimulate the platelet "filpflop", and/or the shedding of phosphollpld protein vesicles resulting 1 in the exposure of procoagulant phospholiplds which would in turn stimulate thrombin formation (23).

Therefore, we think that the effect of SJAMP on thrombin generation in platelet rich plasma can largely be explalned by 1 ts inhibitory action towards thrombin, resulting in an inhlbition of two positive feedback reactions: factor VIII activation and induction of a procoagulant surface. As can be seen in figure $7 \mathrm{in}$ platelet rich plasma a low concentration of SJAMP ( $1 \mathrm{\mu g} / \mathrm{ml}$ ) not only causes a slight increase in the maximal amount of thrombin formed, as it did in platelet poor plasma after triggering with Cephaloplastin, but it also shortens the fultial lag time somewhat. This observation might possibly be explained by a direct interaction of SJAMP with the platelet surface. SJAMP has been reported to Induce the aggregation of human and rabbit platelets (2) which wight result in the generation of a procoagulant surface. Again, as was described for the effect of SJAMP on the Intrinsic pathway of coagulation in platelet poor plasma, at bigher concentrations of SJAMP the inhibltory effect of SJAMP towardis thrombin becomes more important than 1 ts stlmulatory effect on thrombln formation and this results in a decrease in the maximal anount of thrombin formed.

In conclusion, SJAMP has shown to accelerate the decay of endogenous thrombin activity and to stimulate the generation of prothrombinase activity via the intrinsic pathway. However, the Inhibitory effect towards thrombin activity turns out to be more important chan the stimulating effect and this results in a net decrease in the amount of thrombin formed wth increasing SJAMP concentrations $(0-5 \mu \mathrm{g} / \mathrm{ml})$. 


\section{REPERENCES}

1. Pan, H.Z., Chen, J.D., LAn, K.Z. An acldic mucopolysaccharide isolated from stichopus japonicus selenka and some of 1 ts physical and chemical propertles. Chlna. Acta. Pharmacologca. Sinlea. 29, 53-61, 1983

2. LI, J.Z., Bao, C.X., Chen, G.Z., Zhang, G.Z. Antithrombin activity and platelet aggregation by acld mucopolysaccharide isolated from stichopus japontcus gelenka, China. Acta. Pharmacologlca. Sinica. 6, 107-110, 1985

3. Wan; $H_{*}, P^{2}$, M., Huan, $X_{*}, L 1,5$. Treatmeat of some thromboembollc disorders 1th SJAMP. Chllese. J. Hemato1, 6,596-598, 1985

4. van Dan-Mieras, M.C.E., Muller, A.D., van Dlejen, G., Hemker, H.C.

In: Method of enzymatlc analysis. Enzyos 3: Peptidases, protelnases and thelr Inhibltions. Vol. V, 352-394, 1984, Verlag Chemle, Weinhein, Ed : HU Bergmedjer

5. Hemker, H.C., W111ems, G.M., Beguin, S. A computer assisted method to obtain the prothrombin activation velocity in whole plasma independent of thrombin decay processes. Thromb. Haemost. 56, 9-17, 1986

6. Hemker, H.C., Willems, G.M., Béguin, S. Thrombinscope, a personal computer program for the analysis of thrombin generation. Computer. B101. Med. (submitted)

7. Beguin, S. In: the cooperative effects of tissue factor and thrombocytes on thrombln generation; a common site of action for heparia, low molecular welght heparti and other antithrombotic drugs? Thrombinoscopy. Thes1s, Mastricht p. 129-153, 1987

8. ChHu, H.M., Htrah, J., Yung, W.L., Regoeczl, E., Gent, M. Relatlonsh1p between the anticoagulant and antihrombotic effects of heparin in expertmental venous thrombos 18 . Blood. 49, 171-184, 1977

9. Choay, J., Pet1tou, M., Lormeau, J.C., Sinay, P., Casu, B.J., Gatti, G. Structure-activity of relationshlp in heparlin: a synthetic pentasaccharlde wh high affintty for antithrombin III and eliciting high ant1-factor $X_{a}$ activity. Blochem. Blophys. Res. Comm. 116, 493-499, 1983

10. Holmer, E., Mattson, C., N1.1sson, S. Antlcoagulant and antithrombotic effects of theparin and low molecular weight heparin fragments in rabblts. Thromb. Res. 32, 381-391, 1983 
11. Carter, C.J., Kelton, J.G., MArsh, J., Cerskus, A., Santos, A.V., Gent, M. The relationship between the bemorrhagic and antithrombotic properties of low molecular weight hepartin in rabbits. Blood. 59, $1239-1245,1982$

12. Cade, JF., Buchanam, H.R., Boneu, B., Ockelford, P., Carter, C.J., Cerskus, A.L., Hirsh, J. A comparison of the antithrombotic and haemorrhagtc effects of low molecular welght heparin fraction: the Influence of the method of preparation. Thromb. Res. 35, 613-625, 1984

13. Buchanan, M.R., Boneu, B., Ofosu, F., Hirsh, J. The relative importance of thrombin Inhibition and factor $x_{a}$ inhibltion to the antithrombotic effects of heparin. B1ood, 65, 198-201, 1985

14. Koller, M., Schoch, U., Buchmann, P., Largliader., F., Felton von, A., Frick, P.G. Low molecular welght heparin (RABI 2165) as thromboprophylaxis in elective visceral surgery. A randonized double-blind study versus unfractional heparin. Thromb. Haemost. 56, 243-246, 1986

15. Fareed, J., Walenga, J.M., Milliamson, K., Emanuele, R.M., Kumar, A., Hoppensteadt, D.A. Studies on the antithrombotic effects and pharmacokinetics of heparin fractions and fragments. Semin. Hemost. Thromb. 16 , $56-74,1985$

16. Thomas, D.P., Merton, R.E., Lewis, W.E., Barrowcliffe, T.W. Studies in man and experimental animals of a low molecular weight heparin fraction. Thromb. Haemostas. (Stuttg.) 45, 214-218, 1981

17. Thomas, D.P., Merton, R.E. A Low mollecular welght heparin compared with unfractioned heparin. Thromb, Res. 28, 3.43-350, 1982

18. Schmitz-Huebner, U., Freise, G., Reers, B., Ruschemeyer, Ch., Scherer, R., Schonleben, K., van de Loo, J.C.W. Low molecular welght heparin in postoperative thrombosis prohylaxis Thromb. Haenost. 50, 10, 1983

19. Ockelford, P.A., Carter, C.J., Cerskus, A., Smlth, G.A., Hirgh, J. Comparison of the in vivo haenorrhaglc and antithrombotic effects of a low antithrombin III affinity heparin fraction. Thromb. Res. 27 , $679-690,1982$

20. Kakkar, V.V., Djazaert, B., Fok., J., Fletcher, M, Sicully, M.R., Westulck, J. Low wolecular weight heparin and prevention of postoperative deep veln thrombosis. Brit. Med. J, 284, 375-379, 1982

21. Fischer, A.M., Barrowe1iffe, T.W., Thomas, D.P. A comparlson of pentosan polysulphate (SP 54) and heparin I: mechanism of action on blood coagulation. Thromb. Haemost. 47, 104-108, 1982 
22. Doctor, V.M., Sauls, W. Isolation and antlcoagulant properties of a new sulfated kylan: comparson with heparin and a sodium pentosan polysulphate (SP-54). Thromb. Re: $30,573-583,1983$

23. Sandberg, H., Andersson, L-O., Hoglund, S. Isolation and characterization of 1ipid-protela particles containing platelet factor 3 released from human platelets. Bachem. J. 203, 903-911, 1982

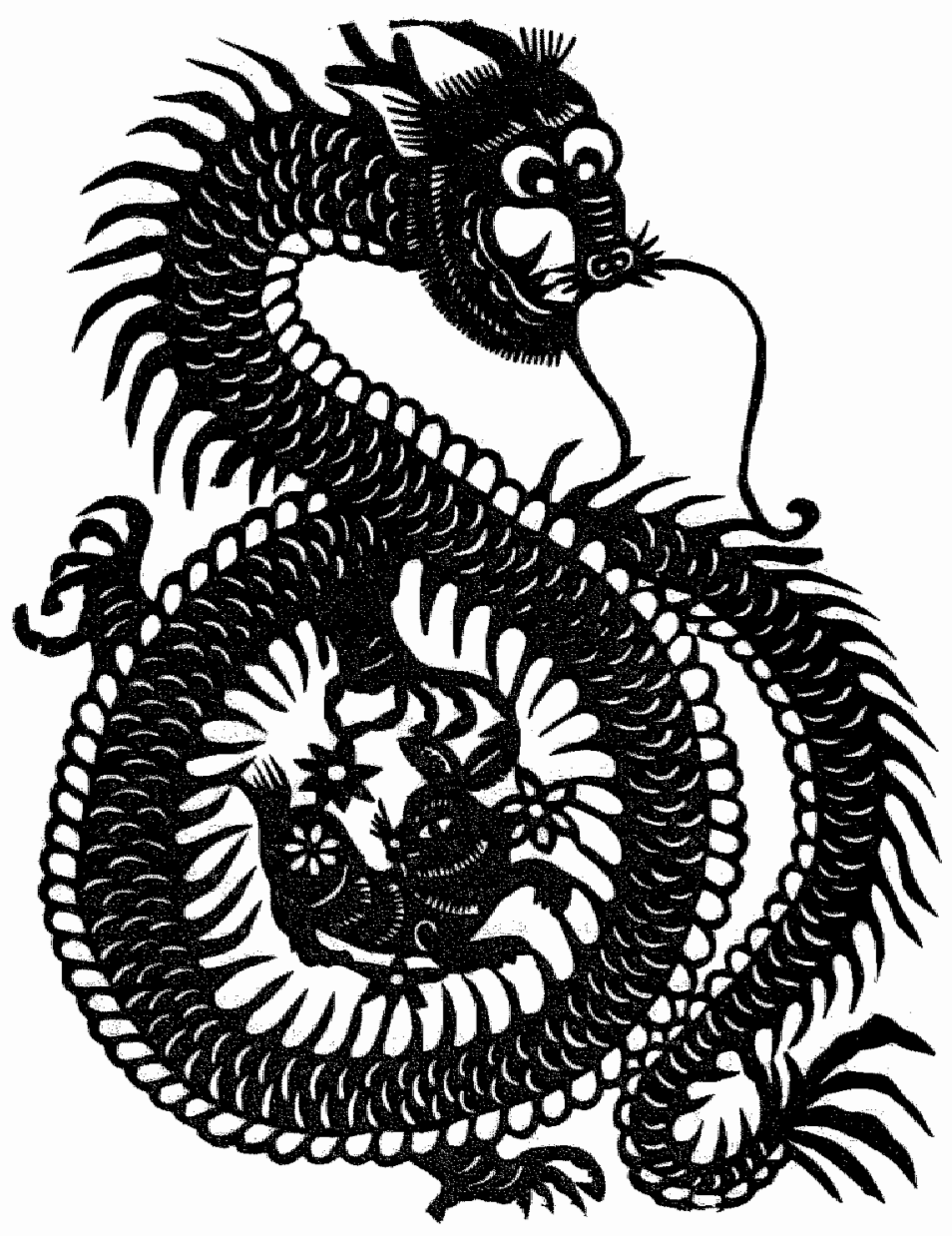


CHAPTBR V

SJAMP, A HEPARIN-LIKE MATERIAL FROM STICHOPUS JAPONICUS SBLBNRA: COFACTOR DEPBNDENCY OF ITS INHIBITORY EFFECT ON THROMBIN ACTIVITY IN PLASMA.

SUMMARY

In this chapter the cofactor dependency of thrombin inhibition by SJAM, a heparin-11ke actd mucopolysaccharide isolated from stichopus japontcus selenka (a sea cucumber), 1s described.

In a purified system, as well as in am euglobulin fraction of normal plasma, thrombin Inhibition by SJAMP was dependent upon the presence of antithrombin III. In the euglobulin fraction it was observed that, after triggering the coagulation with thromboplastin, the presence of SJAMP causes a shortening of the lag time of the thrombin generation process, both In the absence and in the presence of antithrombin III.

When the effect of SJAMP on thrombin Inhibition was studied in an antithrombin III-depleted plasma it was found that in the absence of antithrombin III the inhibition was $20 \%$ of that found after reconstitution of the antfthrombin III-depleted plasma wh antithrombin III. This polnts to the Involvement of other plasma cofactors in the SJAMP-mediated inhibition.

Direct binding studies based on the change In lntrinsic fluorescence of antithrombin III upon interaction wth SJAMP Indicated that SJAMP has a relatively low affinity for antithrombin III; this low affinity is not reflected in 1 ts anticoagulant effect. The discrepancy between the SJAMPantithrombin III binding and the anticoagulant activity of SJAMP may be caused by the 1nteraction of SJAMP wth other proteln cofactors present in plasma. It is concluded that SJAMP exerts it inhibitory activity not only by antithrombin III, but also by other plasma protein such as heparin cofactor II. 
INTRODUCTION

The stchopus Japonicus acld wucopolysaccharide (SJAMP) is a heparin11ke terlal 1solated from stlchopus japonllcus selienka (a sea cucumber) (1). The Inhibltory action of SJAMP on blood coagulation was described to be due to 1 to actlon on thrombln and it was supposed that its mode of action was different from that of heparin $(2,3)$. Th1s hypothesis was based on the observation that the presence of SJAMP caused a prolongation of the thrombin time in both normal and antithrombia III deflcient plasma. This could not be conflrmed by the experiments carried out by our group and described in the previlous chapter. We found that in both platelet poor and platelet rich plasma, SJAMP fust like heparin, inhibits thrombin activity In an antithrombin III dependent reaction, but it cannot be excluded that SJAMP also can make use of other proteln cofactors (e.g. heparin cofactor II). The maln difference between SJAMP and heparin was that, on a weight bas1s, a sixteen-fold higher SJAMP concentration was needed to obtalln the sare effect.

In this chapter we describe our studies on the cofactor dependency of the Inhibition of thrombin by SJAMP. The mode of action was studled in a purifled system, In a plasma preparation devold of all Inhibitors (the euglobulin fraction) and in an antlthrombin III depleted plasma.

MATERTALS AND METHODS

Normal plasma

Blood frow healthy donors was collected in $0.13 \mathrm{M}$ trisodilum citrate (9 volumea of blood to 1 volume of antlcoagulant) and centrifugated for 15 minute at $3000 \times \mathrm{g}$ at $4^{\circ} \mathrm{C}$. Subsequently a second centrifugation was performed for 1 hour at $23000 \times 8$ at $4{ }^{\circ} \mathrm{C}$. The platelet free plasma thus obtalned was used for the preparation of a euglobulin fraction and an antithrombin III-depleted plasma. The platelet free plasma was stored at $-80{ }^{\circ} \mathrm{C}$ unt 11 use. 
Euglobulin fraction

Deflbrinated plasma was used as a starting aterlal for the preparation of the euglobulin fraction. The defibrinated plasma was prepared by aling 50 volumes of plasma wth 1 volume reptilase solution. After clotting for 10 minutes at $37^{\circ} \mathrm{C}$ the clotted plasma was kept at $0^{\circ} \mathrm{C}$ for another 10 minutes. The fibrim formed was removed by winding it on a small plastic spatula. The euglobulin fraction prepared froa defibrinated plasma by acid precipitation at low lonic strength as described by Josso et al (4). The precipitate was dissolved in Michaelis buffer ( $\mathrm{pH} 7.35$ ) contalning $0.02 \mathrm{M}$ trisodium citrate. All preparation steps were carried out ln plastic materials.

\section{Ant1thrombin III depleted plasma}

Antithromb1n III depleted plasma was prepared by gently atirring 2 ml. of human plasma with $0.8 \mathrm{ml}$ of a suspension of anti-antithrombin IIIsepharose (gift from Dr. Tran Huu Tri, Basel) for 18 hours at $4{ }^{\circ} \mathrm{C}$. After adsorption the antithrombin activity in the plasma was not influenced by the addition of $10 / \mathrm{ml}$ of heparin.

\section{Purtfled thrombin}

Human thrombin was prepared as previously described by Pleteher and Nelsestuen ( 5$)$.

\section{Purtfled ant 1 thrombln III}

Human ant1thrombin III was prepared by polyethyleneglycol precip1tation of bartum citrate-adsorbed plasma, followed by affinity chromatography on heparin-sepharose (6). Finally heparin was removed by lon-exchange chrouatography (7). Bovine antlthrombin III was prepared as previously described (6). 
Thromboplastin

Human brain thromboplastin was prepared by a modification of the nethod of Omen al (B). The preparation obtalned was homogenized in a potter Bivehjen howogeniser for 3 winutes, centrifugated $2000 \mathrm{x}$ for 5 minutes and stored at $-20{ }^{\circ} \mathrm{C}$. Prior to uge the preparation was thawed, diluted 1:40 wth $0.05 \mathrm{M}$ TrLs-HCl (pH 7.35) contalning $0.1 \mathrm{M} \mathrm{CaCl}$, and prewarmed at $37 \mathrm{C}$ for 1 hour. When morral plasma was clotted with thls thromboplastin dilution under the experimental conditions used in this study the clotting time was $B O$ seconds.

\section{StLchopus Japonicus actdic mucopolysaccharlde (SJAMP)}

SJAMP was kindly supplied by Dr. Jla-Zeng L1, Ingtitute of Bematology, Tlanjln, China. The compound was lsolated and purifled by the Blochemical Laboratory of TLanjin Medical and Pharmacological Institute, China.

\section{Buffers}

Buffer A: $0.05 \mathrm{M} \mathrm{Tr} 1 \mathrm{~s}-\mathrm{HCl}, 0.1 \mathrm{M} \mathrm{NaCl}, \mathrm{pH} 7.35$

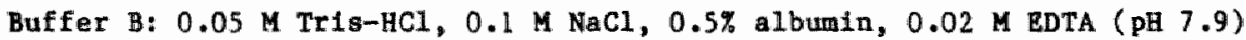

\section{Commercial reagents}

Chromogentic mubstrate $\$ 2238$ for thrombin was obtained from Kab1 Vitrum (Stockholm, Sweden). Reptilase was obtalned from Laboratories Stago (Asnleres, Prance). 4 th International standard Heparln was obtained from the National Institute for Biological standards and Control (NIBSC). All other chemicals used were of the highest grade comerclally avallable.

Measurement of thrombin Inhibition in a purifted system.

The Influence of SJAMP on the Inhibition of thrombin by antithrombin III studied in a purtfled aystem. The Inftial rate measurements were carried out under psetudo first order conditions. An incubation mixture conslsting of antithrombin III (400 nM), SJAMP (range $0.5-3 \mu \mathrm{g} / \mathrm{m} 1$ ) and 
buffer A was incubated for 4 winutes at $37{ }^{\circ} \mathrm{C}$. After this lncubation purlfied thrombin ( $10 \mathrm{nW}$ ) was aded to the incubation nixture and at fixed time intervals after the addition of thrombin, 15 wl allquots were subsampled Into tubes contalning $445 \mathrm{\mu l}$ of buffer $\mathrm{B}$ and $50 \mathrm{ul}$ of $\$ 2238$ (4 m). Amidolytic activity ras read immediately at 405 nm in a spectrophotometer (LRB DItrospec II). The thrombin activity was calculated from a referemce curve constructed with a serles of dilutions of a standard thrombin preparation.

Measurement of thrombin generation in an euglobulin fraction and an antithrombin III depleted plasma

For the measurement of thrombin generation the procedure described by Hemker et al (9) was used. To $240 \mathrm{\mu l}$ of sample (euglobulln fraction or antithrombin III depleted plasma), $60 \mathrm{j1}$ buffer A containing SJAMP at the concentration to be tested was added and the mixture was incubated for 5 minutes at $37^{\circ} \mathrm{C}$. The generation of thrombin activity was triggered by the addition of $60 \mathrm{\mu l}$ of the thromboplastin dilution containing $0.1 \mathrm{M} \mathrm{CaCl}_{2}$. At flxed time intervals, $10 \mathrm{jl}$ allquots of incubation ixture were subsampled Into tubes contalning $465 \mu 1$ of buffer $B$ and $25 \mu 1$ of 52238 (4 mM). The subsampling tubes were Incubated for 2 minutes at $37^{\circ} \mathrm{C}$, and then the reaction was stopped by adding $300 \mathrm{\mu l}$ of concentrated acetic acld. The pipettes for sampling and for stopplng the reaction mere connected to an Apple IIe computer. A program was developed that allowed automatic registration of the ments of sampling and stoppling. The optical density was read at $405 \mathrm{~nm}$ in the spectrophotometer. Frow the change in optical density and the time interval between sampling and stopping the $\Delta 0 . D . / \mathrm{m}$ in was calculated by the computer $(10)$.

Measurement of the binding of SJAMP to ant1thrombln III

The Interaction of SJAMP with entithrombin III was deternined by measuring changes in the intrinsic fluorescence of antithroabla III (11). Small allquots of SJAMP $(10 \mathrm{\mu g} / \mathrm{ml})$ were added in accegsion to solution of bovine antithrombin III (2 $\mathrm{MM}$ in $0.05 \mathrm{M} \mathrm{Tr1s,} 0.12 \mathrm{M} \mathrm{NaCl}$ and pH 7.9 room temperature). After each addition the intrinsic fluoreacence intensity 
of the antithrombin III was determined using an excitation wavelemgth of 280 with a 2 no 311 twidth and an emission wavelength of $340 \mathrm{~nm}$ wh a 5 wistidth. The lacrease in fluorescence intensity was plotted against the amount of SJAMP added. The binding constant was estimated from the SJAMP titration data using a non-1inear least squares computer fit to the equat Lon:

$$
\Delta \mathrm{F}=\frac{\Delta \mathrm{Pmax}}{-\left(R+T+K-\sqrt{(R+T+R)^{2}}-4 T R\right)^{\frac{1}{2}}}
$$

$2 \mathbb{R}$

where, $\triangle F$ is the change in fluorescence, $R$ is the total concentration of antithrombim III, $T$ is the total concentration of SJAMP and $\mathbb{R}$ is the dissociation constamt of the SJAMP-antithrombin III complex. 
RESULTS

The inhibitory effect of SJAMP on thrombin activity in a purified syster

The Inhibition of purified thrombin by antithrombin III in the presence of varlous amounts of SJAMP was measured under paeudo first order conditions. In figure 1 the rate constant $(k)$ of inblibition of thrombin is plotted agalnst the SJAMP concentration. In the absence of SJAMP the $k$ of thrombla Inhibition by purifled human antithrombin III was shown to be 0.35 min ${ }^{-1}$. The rate constant of thrombin inhibition increased linearity with the SJAMP-concentration $1 \mathrm{n}$ the range tested $(0.5 \mu \mathrm{g} / \mathrm{m} 1-3 \mu \mathrm{\mu g} / \mathrm{ml})$. The Inhibition of thrombin activity by SJAMP was completely dependent upon the presence of antithrombin III. No Inhibition of thrombin activity was found in the absence of antithrombin III. From these results we conclude that, in the purified system used, the Inhibitory action of SJAMP towards thrombln 1s mediated by antithrombin III. From the straight line of fig. 1 we calculate a gecond order rate constant of $k=1.4\left(\mathrm{~m}^{-1} \mathrm{n}^{-1} / \mathrm{ug}_{\mathrm{g}} \mathrm{ml}\right)$.

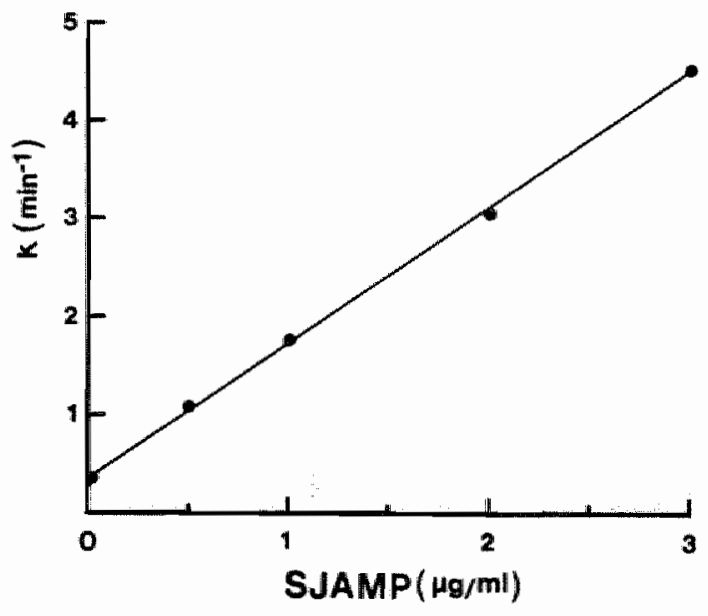

F1g. 1. The rate constant of thrombin Inhibition In purifled aysten as a function of the SJAMP concentration. 
The Inhlbitorg effect of SJAMP on thrombin generation in the euglobulin fraction

Pollowing the study of the Inhibitory effect of SJAMP towards thrombin In a purified sgatem, the Inhibitorg effect of SJAMP on thrombin generation 1n an euglobull fraction was invegtigated. To ensure that there was no realdual antithrombin activity in the euglobulin fraction, we firot determined the effect of standard heparin on the generation of thrombin activity in thit experimental oystem. As show in Fig. 2, thrombin generation in the euglobulin preparation, as determined by the measurement of amidolytic activity, was not influenced by the presence of heparila. No thrombin Inhtbition was observed in the euglobulin fraction, indicating that no residual antithrombin III actirity was present in this fraction. When the

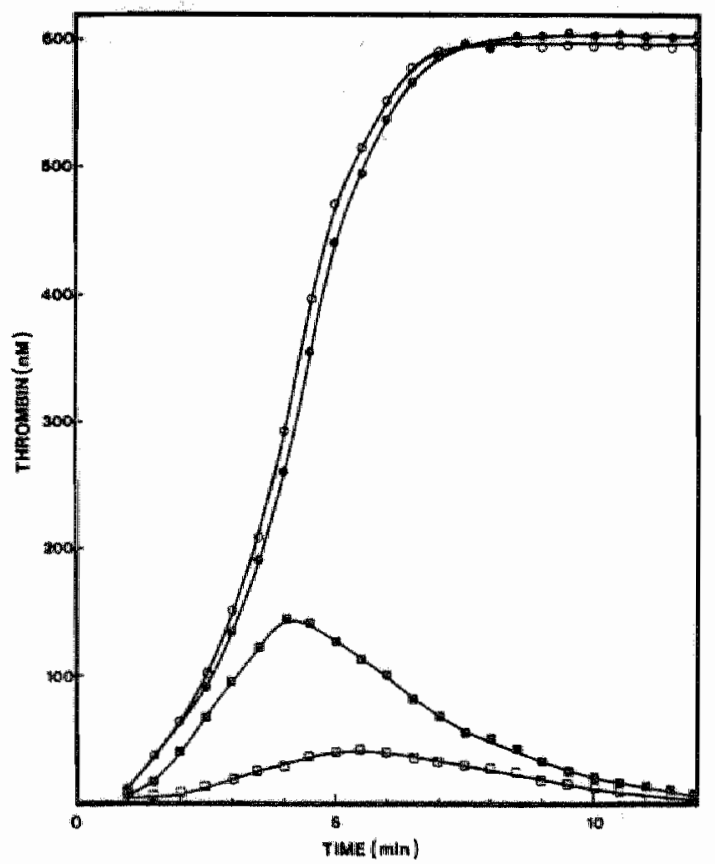

11g. 2. Effect of heparin on the generation of thrombin activity in an euglobulin preparation before and after reconstitution with antithrombla III.

buffer

0 heparin $(0.03 \mathrm{u})$
AT III (2000 nM)

D AT III $(2000 \mathrm{nM})$ and heparin $(0.03 \mathrm{v})$ 
euglobulin fraction was reconstituted with human atithrombin III, Inhibition of thrombin occured both in the presence and in the absence of heparin. As could be expected, the inhibitory action was wore pronounced when heparin was present. The amidolytic activity in the reconstituted euglobulin fraction eventually disappeared completely, which means that the euglobulin fraction was also free from $\alpha_{2}$-macroglobulin because the $a_{2}$-macroglobulin-thrombin complex still displays activity towards chromogenic substrates.

The effect of SJAMP on the generation of thrombin activity in the euglobulin fraction was deterwined under the same experimental conditions as used for the determination of the heparin effect. The results of these experiments are shown in figure 3. It can be concluded from these figures that the effect of SJAMP has much simflarity to the effect of heparin.

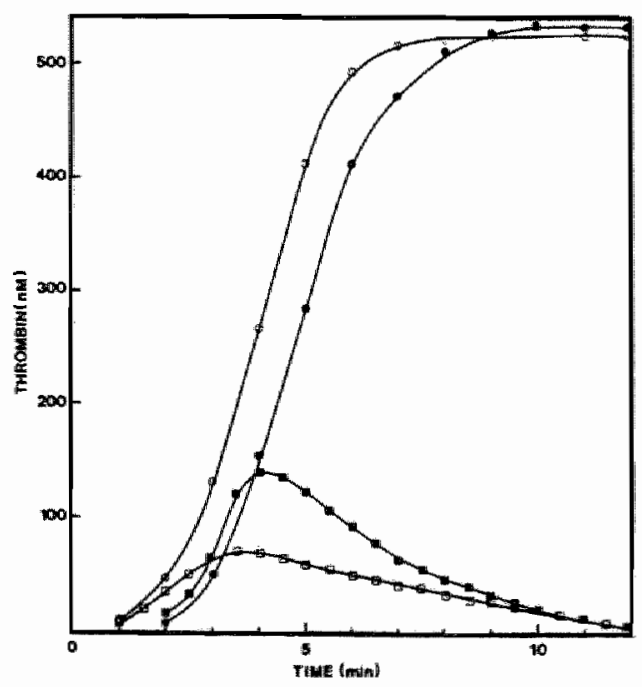

Fig. 3. Effect of SJAMP on the generation of thrombin activity in a euglobulin preparation before and after reconstitution with ant Ithrombin III

- buffer

O SJAMP $(3 \mu \mathrm{g} / \mathrm{ml})$
AT III (2000 nM)

SJAMP ( $3 \mathrm{Hg} / \mathrm{ml})$ and AT III $(2000 \mathrm{nM})$

However, a difference between SJAMP and heparin can be noted. Whereas heparin has no Influence on the lag time of thrombin generation in the euglobulin fraction, SJAMP shortens the lag time of the thrombin burat. 
The Inhibltory effect of SJAM on throwbin generation in antithrombin III depleted plasma

The effect of SJAMP on the generation of thrombin activity in antithrombin III-dlepleted plasma 1 s ghown In FIg. 4. As could be expected, the presence of SJAMP caused a strong imhibition of thrombin activity when the antithrombin III depleted plasma was reconstituted with antithrombin III However, the lahibition of thrombin activity was not only seen in the reconstituted plagma, SJAMP also excerted some inhibitory activity in antithrombin III depleted plasma. The data shown In figure 4 indicate that in the plagma reconstituted with antithrombin III also other plasma protelns are Involved in thrombin Inhibition. About $20 \%$ of the Inhibitory

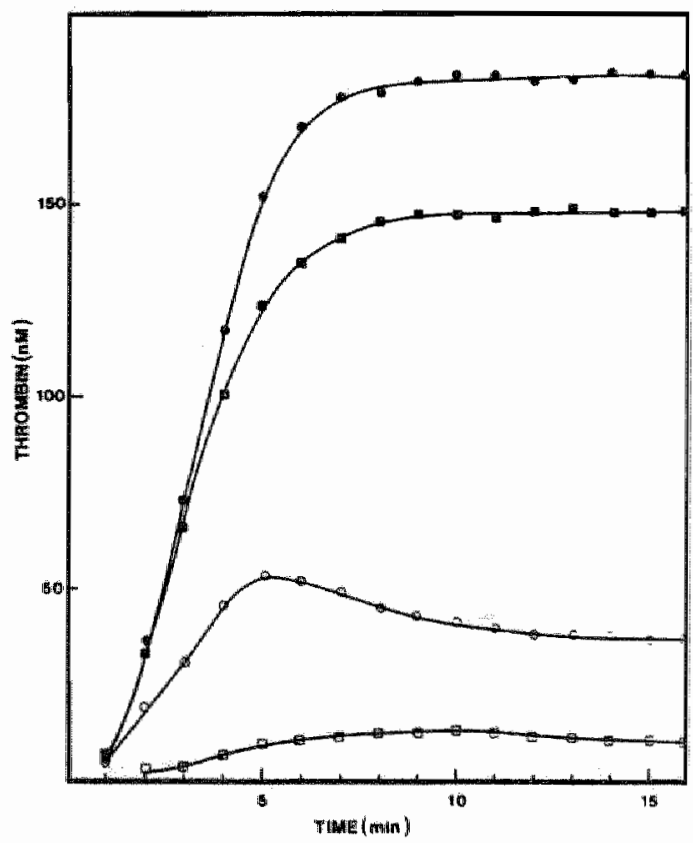

F1E. 4. Befect of SJAMP on thrombin activity 1n AT III depleted plasma before and after reconstitution th antithrombin III

- Buffer

O AT III (2000 nM)

SJAMP

(3 $\mu \mathrm{g} / \mathrm{w} 1)$

口 SJAMP $(3 \mathrm{\mu g} / \mathrm{mL})$ and AT III (2000 nM) 
effect is wediated by these inhibitors. The observation that the amidiytic activity in the antithrombin III-depleted plasma with recomstituted antthrombin III does not go back to the zero level as it did in the reconstituted euglobulin fraction can be explained by the presence of an $\alpha_{2}$-macroglobulin-thrombin complex in the former aixture while it is absent fron the euglobulin fraction (9).

\section{Binding of SJAMP to antithrombin III}

The SJAMP-antithrombin III binding was sudied by measuring the changes In the Intrinsic fluorescence of antithrombin III upon successive additlons of SJAMP. In figure 5 the increase in fluorescence $\left(P-F_{0}\right)$ is plotted agalnst the amount of SJAMP added. The dissociation constant $\left(\mathrm{K}_{\mathrm{d}}\right)$ and the $\Delta F_{\max }$ of SJAMP were obtained from the data by computer fit procedure as described In the section Materials and Methods. The $\mathrm{K}_{d}$ value was 0.14 $\mathrm{mg} / \mathrm{ml}$, whlch, based on a molecular welght of 30,000 for SJAM, was 4.6 JM. The $\Delta F_{\max }$ was only $15 \%$ of that found for the antithrombin III heparin interaction (12).

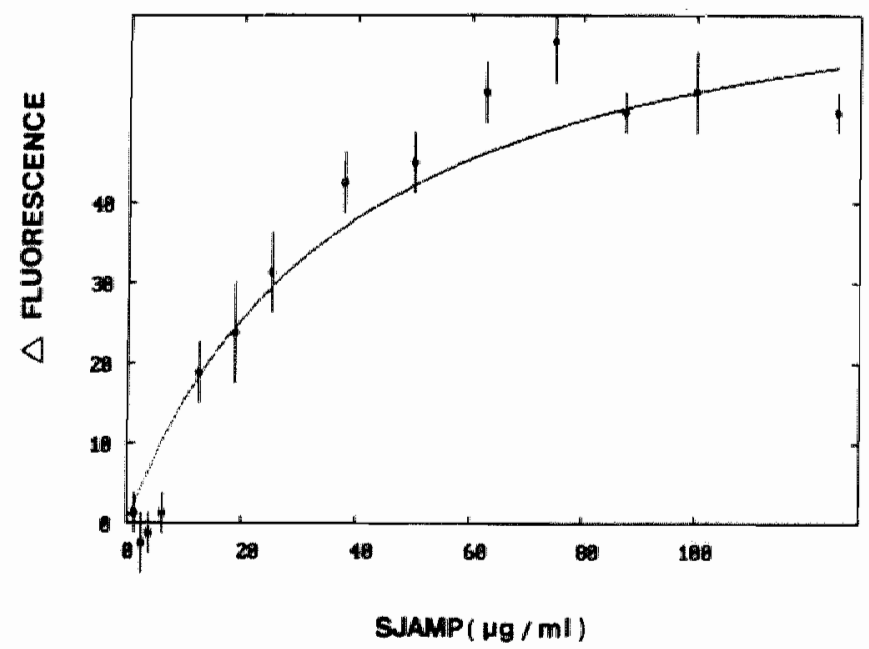

P1g. 5. Measurement of the binding of SJAMP to antithrombin III. See text for further detalls 
DTSCUSSION

The enhancing effect of heparin and 1 ta analogues on the inhibition of the coagulation serine proteases by plasma Inhibltors has been ahown to depend largely on the ability of these compounds to bind to the heparin cofactore 1.e. antithrombin III and heparin cofactor II (13-18). The inhibition by atithrombin III is considered to be the predoninant mechanisia for anticoagulation in the case of the heparins themselves. The posslbility that part of the lahibltory effect of heparin congeners on coagulation 18 not mediated by antithrombin III was reported in the 11 terature $(19,20)$.

Previous studes suggested that SJAMP acts as an ant1coagulant by inactivation of thrombin but that this inactivation 18 not dependent on antithrombin III $(2,3)$. Our observations of the effect of SJAMP on thrombin generation in plasma described in the prevlous chapter are not in agreement wth these literature findings, however. We obserwed that SJAMP accelerates the decay of thrombin activity in plasma in an antithrombin III dependent manner comparable vith heparin (see chapter 4). The investigations presented in this chapter also demonstrate that the inhibitory action of SJAMP towards thrombln depends on antithrombin III. Th1s conclusion is based on our observations in a purified system, In an euglobulin fraction which is a plasma fraction devold of all inhibitors and in an antithrombin III depleted plasma. In the purified system the Inhibitory effect of SJAMP was completely antithrombin III dependent (FIg. 1). In the euglobulin fraction, SJAMP will not lahibit thrombin activity when antithrombin III $1 \mathrm{~s}$ absent (Fig. 3). From these experiments a direct action of SJAMP an thrombin 19 excluded. The antithrombin III dependency of the thrombin inhibition by SJAMP 16 also confiraed by the experiments in antithrombin III depleted plama (Fig. 4). However, in this system about $20 \%$ of the thrombin inhibition by SJAMP nust be explained by an antithrombin III independent process. Preliminary experiments (not represented) indicate that this antithrombin III-Independent Inhibition may be medlated by heparin cofactor II.

It can be noticed that in the euglobulin fraction SJAMP causes a silght shortenlag of the lag phase in the process of thrombin generation, even in the presence of antithrombin III. A simlar observation has been described 
in the preceeding chapter, but at the moment we have no explanation for this phenomenon.

Binding of heparin to antithrombin III or heparin cofactor II has been described to be essential for its anticoagulant activity (21-23). It has been postulated that a heparin-induced conformational change in the inhibitor structure accelerates the rate of formation of an inactive conplex between antithrombln III and thrombin $(24,25)$. Heparin with low affinity for antithrombin III shows a relatively low efflciency of thrombin inhibition, while heparins wth high affinlty for antithrombin III are efficient stimulators of this inhibition (26).

To further characterlze the interaction between SJAMP and antithrombin III, we determined the binding of SJAMP to antithrombin III by a fluorometric binding assay (FIg. 5). The binding constant $\left(K_{D}\right)$ of SJAMP to antithrombin III was $4.6 \mu \mathrm{M}$. In comparison to standard heparia $\left(\mathrm{K}_{\mathrm{D}}=0.05 \mu \mathrm{M}\right)$ SJAMP has a rather low affinity for antithrombin III (12). However, the second order rate constants for the Iahibition of thrombin by SJAMP and heparin are respective1y $1.4 \mathrm{mln}^{-1} / \mu \mathrm{g} / \mathrm{ml}$ and $38.7 \mathrm{~min}^{-1} / \mathrm{\mu g} / \mathrm{ml}$ (12). Therefore, the anticoagulant effect of SJAMP is stronger than would be expected from its affinity for antithrombin III. One explanation for this observation could be that the conformational change in antithrombin III induced by SJAMP would produce a more effective antithrombin activity than the conformational change induced by heparin. Am alternative, and perhaps more 11kely, explanation could be the interaction of SJAMP with other plasma inhibitors. This point remains to be inveatigated.

In conclusion, SJAMP acts as an anticoagulant not only by atinulating the Inhibition of thrombin by antithrombin III but $1 t$ alao acts by an effect of other plasma inhtbitors such as heparin cofactor II. 


\section{REFBRENCES}

1. Pan, H.Z., Chen, J.D., LIn, K.Z. An acidlc mucopolysaccharlde 1solated frow atlchopus japonicus aelenka and some of 1 ts physlcal and chentcal properties, Chllan Acta Pharacologica Sinica 29, 53-61, 1983

2. Wan, H., Pan, M., Huan, X., LI, S. Treatment of Bome thromboembollc disorder fth SJAMP. Chinese J Hewato1. $6,596-598,1985$

3. L1, J.Z., Bao, C.X., Chen, G.Z., Zhang, G.Z. Antithrombin activity and platelet agregation by acid mucopolgsaccharide lsolated from stichopus Japonicus Belenka. China Acta Pharwacologlca S1nica. 6, 107-110, 1985

4. Josso, F., Prou-Warte11e, 0. Bxploration de I"hemostase. In: Techniques en Hematologle, D. Alagile et al. Eds: Plamarion Paris, 101-208, 1972

5. Pletcher, H., Nelsestuen, G.L. The rate-determining step of the heparin-catalyzed antithrombin/thrombin reaction is lndependent of thromb1t. J. B1ol. Chem. 257, 5342-5345, 1982

6. Thaler, E., Schmer, G. A simple two-step lsolation procedure for human and bovine antithrombin II/III (heparin cofactor): a comparison of two methods. Br. J. Haemato1. 31, 233-243, 1975

7. Muller-Andersson, M., Borg, H., Andersson, L.0. Purlfication of antithrombin III by affinity chromatography. Thromb. Res. 5, 439-452, 1974

B. van Dam-Mieras, M.C.E., Muller, A.D., van Dieijen, G., Hemker, H.C. In: Methods of enzymatic analysis. Enzymes 3: Peptidases, proteinases and their Inhibitors. Vol. $\nabla, 352-394,1984$. Verlag Chemie, Weinheim, dids: Hu Bergmeyer.

9. Hemker, H.C., WLlems, G.M., Beguin, S. A computer assisted method to obtain the prothrombin activation velocity th thole plasma independent of thrombin decay process. Thromb. Haemost. 56, 9-17, 1986

10. Hemker. B. C., W11lems, G.M., Beguln, S. Thrombinoscope, a personal computer progran for the analysis of thrombln generation curves. Comput. Blol. Med. (Submitted)

11. Jordan, R.E., Oosta, G.M., Gardner, W.T., Rosenberg, R.D. The binding of low-molecular velght heparin to hemostatic enzymes. J. B1ol. Chem. $255,10073-10080,1980$

12. Lindhout, T. Personal Communication. 
13. de Swart, C.A.M., Nijmeyer, B., Andersson, L-0., Holmer, B., Versehoor, L., Bouma, B.N., Sixma, J.J. Blimination of high afinity heparin fractions and their anticoagulant and 11pase activity. Blood. 63, $836-842,1984$

14. Rosenberg, R.D. Heparin-antithrombin system. In: Hemostasis and Thrombosis. Basic princlples and clinical practice. R.W. Colman, J. Hirsh, V.J. Marder, B.W. Salzman, Bds: J.B. Lipplncott Co. Philadelphia and Toronto. 966-985, 1982

15. Rosenberg, R.D., Lam, L. Correlation between the structure and fucntion. of hepar1n. Proc. Nat1. Acad. Sc1. 76, 1218-1222, 1979

16. Marton, R.E., Thomas, D.P., Havercroft, S.J, Barrowcliffe, T.W., Lindahl, U. High and low affinity heparin compared with unfractionated heparin as antithrombotic drug. Thromb. Hsemost. (Stuttg.) 51, 254-256, 1984

17. LIndhout, T., Baruch, D., Schoen, P., Franssen, J., Hemker H.C. Thrombin generation and Inactivation 1 the presence of antithrombin III and heparin. Blochemistry. 25, 5962-5969, 1986

18. Ofosu, F.A., Mod1, G.J., HIrsh, J., Buchanan, M.R., Blajchman, M.A. Mechanisms for inhibition of the generation of thrombin activity by sulfated polysaccharldes. Ann. New York. Acad. Sc1. 485, 41-55, 1986

19. Ofosu, F.A., Blacjhman, M.A., Hirsh, J. The inhibition by heparin of the intrinsic pothway activation of factor $X$ in the absence of ant1thrombin III. Thromb. Res. 34, 125-133, 1984

20. Salzman, E.W., Rosenberg, R.D., Smith, M.H., Lindon, J.N. Effects of heparin and heparin fractions on platelet aggregation. I. Clin. Invest. $65,64-73,1980$

21. Tollefsen, D.M. Activation of heparin co-factor II by heparin and dermatan sulfate. Nouv. Rev. Fr. Hematol. 26, 233-237, 1984

22. Thomas, D.P., Merton, R.E., Barrowcllffe, T.W., Thunberg, L., Lindahl, 0. Effects of heparin oligosaccharides with high affinity for the antithrombin III in experimental venous thrombosis. Thromb. Haemost. 47, $244-248,1982$

23. Bjork, I., Nordling, R. Bvidence of chemical modiflcation for the involvement of one or more tryptophany1 residues of bovine antithrombin In the blading of high affinity heparin. Eur. J. Blochem. 102, 497-502, 1979 
24. Mordenman, B., Danlelsson, A., sjorli, 1 . The biadiag of low-affindty and high-affinity heparin to antithrombln. Eur* J. Blochem. 90, 1-6, 1978

25. Fareed, J., Halenga, J.M., H114awson, R., Bmanuele, R.M., Kumar, A., Hoppensteadt, D.A. Studies on the antithrobotic effects and pharwacokinetics of heparin fractions and fragments. Semin. Hemost. Throwb. 11, 56-74, 1985

26. Choay, J., Pet1tou, M., Lormeau, J.C., Slan, P., Casu, B., Gatt1, G. Structure-activity relatlonghlp in heparin: a synthetic pentasaccharide wth high affinity for antithrombin III and eliciting high ant $\mathrm{x}_{a}$ activity. Blochem. Blophys. Res. Cowa. 116, 492-499, 1983

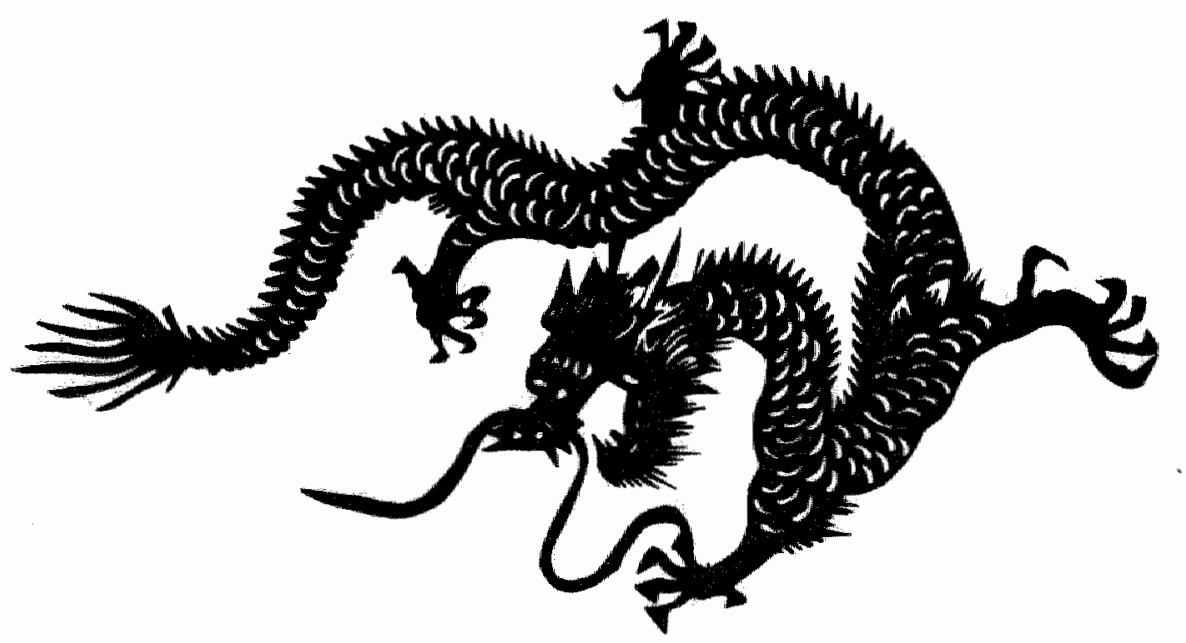


CHAPTER VI

GBMERAL DISCUSSION

The alm of the work presented in this thesis was to do biochemical research in the field of blood cosgulation that bas a direct relation to medlcal questions.

The studles have thrombin activity in plasma as a central theme. In the studies described in the first two chapters the thrombin generation was studied in plasma systems that were not normal from a physiological polnt of view. The abnormality was elther a coagenital deficlency of a single coagulation proteln (haemophilia $A$ or $B$ ) or a reduction in the effective level of the vitamin $\mathrm{K}$-dependent factors brought about by oral anticoagulation. In this aspect these studies were related to earlier work from clinical laboratories because clinical discovery of a coagulation abnormality very often precedes the discovery of the related clatting protein. Indeed, a large amount of the present knowledge about physlological blood coagulation has been accumulated by the study of patients who lacked a specific clotting protein. The difference with the older studies resides in the fact that, because of the avallability of modern neasuring techniques and of purifled clotting factors, we can now answer questions that were hardly accessible to the clintcal investigator of earlier days.

In the second part of the thesis studies on the anticoagulant effect of SJAMP, heparln-11ke compound laolated from the stichopus japonicus selenka, (a specles of sea cucumber), were described. The alm of these studies to better understand the Inhibition of thrombin activity in plasma by this substance.

Since Biggs and Nossel discovered that haewophlliac plasma do not generate a normal amount of thrombin activity by the thromboplastindependent pathway when dilute thromboplastin 1 used to trigger coagulatIon (1) and Josso and prou-Wartelle found that factor VII is essential for the procoagulant activity of a haemophiliac plagma using a dilute thrombio- 
plastin (2), the relationshlp between the classical intrinsic and extriasic pathuay had been demonstrated but olll remalned somewhet indistinct for several years. In the past ten years, great blochemlcal advances bave been ade in this fleld. We can now 1 sollate all known coagulation protelns and reconstruet parts of the plastatle coagulation gystem wh these purified compounds. Based on such a procedure, Gsterud and Rapapport directly confirmed that a reaction product of factor vil/thromboplastio could activate the factor IX (3). The physlological importance of this pathway remalned to be observed. In vitro evidence accumulated that the rate of factor $X$ activation vla factor VII/thromboplastin dependent activation of factor IX 18 much smaller than that of the direct activation of factor $X$ via a factor VII $/$ /thromboplastin complex (4-6). This makes it difficult to accept that the thromboplastin-dependent activation of factor IX is of primary importance in vivo.

In chapter II of this thesis, a quantitative study of the contribution of the factors IX and VIII to the process of thrombin generation after triggering coagulation wth thromboplastin was presented. We found that, when coagulation is triggered with a concentration of thromboplastin normally used in in vitro tests, thrombln generation is the same in congenttal factor IX deficlent plasma and in congental factor IX deficlent plasma reconstituted with purified factor IX. Also with factor WII deflcient plasma, thrombin generation in factor VIII deficlent plasma is the same as in factor VIII deflelent plasma reconstituted with purifled factor VIII when coagulation is triggered with a thromboplastin concentration normally used in in vitro teats. When, however, coagulation is triggered with low concentration of thromboplastin, a clear dependency of thrombin generation on the amount of factor IX or factor VIII present becomes evident factor IX concentration lower than 30 nM (about $40 \%$ clotting activity) and a factor VIII concentration lower than $0.3 \mathrm{U} / \mathrm{m} 1$ (about $30 \%$ eloting activity), reapectively.

These results clearly show that, in situatlons where only small amounts of thromboplateln are avallable, the factor IX and VIII play an Increasing1y Important role in plasma coagulation. This incerrelation between the two classical pathwaye could give a proper explanation for the fact that in haemophlliac patients the deficlencles in the intrinsic pathway are not compensated by the intact extrinstic pathway. It is lateresting to note in 
this respect that haemophillac patients tend to bleed In throaboplastin poor organs (folnts, muscles).

The family of the vitamin $k$-dependent clotting factor includes prothrombin and the factors VII, IX and $X$. The role of vitamin $\mathrm{K}$ is to promote the carboxylation of a distinct series of glutamic acld residues of the N-terminal end of the polypeptide chaln into $\mathcal{H}$-carboxylated glutamic acid residues. These residues are required for the binding of the clotting factors to negatively charged phosphollpld surfaces via $\mathrm{Ca}^{2+}$-bridges. This interaction with phospholipid surfaces is necessary for their participation in the coagulation process (7). Vitamin $K$ antagonists, such as dicoumarol derivatives, interfere with the carboxylation of the vitamin K-dependent clotting factors. Treatment with vitamin $\mathrm{K}$ antagonist therefore results in the synthesis of blologically imactive but immologically detectable forms of the vitamin $K$-dependent protelns. These Inactive forms are called decarboxy factors or PIVKAs (8-12).

Due to the different half-life times of vitamin $\mathrm{K}$-dependent clotting factors, oral anticoagulation atarts with the reduction of factor VII activity, later the reduction of the factors IX, $X$ and prothrombin follows (12). Therefore, if an oral anticoagulant is administered, the concentrations of the factor VII, $X$ and prothrombin that together determine the prothrombin tlme may occur in a large variety of combinations. Any experimentally found prothrombin tilme may in fact be due to an infinity of different sets of concentrations of the prothrombin and the factors VII and $X$. From clinfical practice it is known that a given value of prothrombin time Indicates adequate anticoagulation, we till do not know to what level of which clotting factor is necessary for the effective anticoagulant response. For instance, it is not known whether reduction of the factor VII activity, and thus a prolonged prothrombin time during the initial period of treatment means an effective antithrombotic response in vivo. It is also possible that an effective in vivo antithrombotic response is only reached after sufficient reduction of the factor $X$ or the prothrombin activity.

In chapter III of this thesis, a study of the relative importance of vitam $\mathbb{R}$-dependent clotting factors on prothrombinase activity in dicoumarol plasma was described. We found that the addition of purifled factors VII, IX or $X$ to plasma from deeply anticoagulated patients 
(throubotest values in the range 10-15\%) did not influence the rate of prothrombinase formation and the mount of prothromblnase formed. only the anount of prothrombin orlginally pregent in the dicoumarol plasma decerwined the course of thrombin generation.

To further Investigate the level below which the vitamin $\mathbb{R}$-dependent clottling factors atart to have an effect on the prothrombinase activity, purtfled factors VII, IX and $X$ were added in Increasing amounts to plasmas deflelent in prothrombln and factors VII, IX and $X$, respectively. It was show that the concentratlons necessary to obtain half maximal prothrombinase formation were $<1 \%$ for factor VII, $5 \%$ for factor IX and $10 \%$ for factor $X$. The prothrombinase activity showed to increase linearily with 1ncreasing amounts of prothrombin added. From this study we conclude that only the changes in the prothrombin level must be held responsible for antithrombotic effect of ora1 antlcoagulant therapy. This also suggests that the estimation of prothrombin activity should be sultable for mont toring oral anticoagulant therapy.

Conventional heparin has been used in clinlcal practice about 40 years. The trement is not alwags efflcient, however, and the dose of heparin administered is 1 inlted by the bleeding risk. Moreover, some patients develop thrombopenia and thrombotic complications in associations with heparin therapy. These clinical findings have greatly stimulated the interest in compunds related to heparin which are reported to posses greater antithrombotic effectiveness whlle producing less bleeding than conventlonal heparin and that are therefore supposed to have an increased "therapeutle window" (13-15). SJAMP, a heparln ilke acidic mucopolyaceaharide laolated from the sea cucumber (atichopus japonicus selenka), has recently been studled a potential new anticoagulant drug (16). Its action on blood coagulation has been reported to be due to inhlbltiom of thrombin activity. but the preclse sechanisin of its intervention in coagulation and the cofactor dependency of the inhibitory effect are not yet clear.

In chapter IV of this thesis, a study of the effect of S.JAMP on throbin generation in plasma described. We found that in platelet poor plasma the main inhibitory effect of SJAMP on chrombin generation after triggering the coagulation via the extrinsic pathway is a reduction of the maximal amount of thrombln formed and an acceleration of thrombin decay. 
Both phenomena can be attributed to a SJAMP dependent Increase of antithrombin activity. The apparent second order rate constant of SJAMP dependent thrombin decay in plsma $181.5 / \mathrm{mln}^{-1} / \mathrm{\mu g} / \mathrm{ml}$. This means that, calculated on a welght basls, the Inhlbitory effect of SJAMp towards the thrombin activity is about sixteen-fold weaker than that of international standard heparin. Like heparin, SJAMP does not Inhibit the prothrombinase activity in the extrinsic pathway in plasma.

When the effect of SJAMP was studied in platelet poor plasma after triggering the coagulation via the intrinslc pathway, an additional effect of SJAMP was observed; SJAMP Increased the lag time in the thrombin generation process. Thts can probably be explained by an inhibition of the feedback activation of factor VIII by thrombin. Previous studies suggested that the lag time in the thrombin generation process reflects the time needed for the activation of factor VIII by (low amounts of) thrombin (17). Yet, SJAMP showed to stimulate the prothrombinase activity in the intrinsic pathway in a dose dependent way. For the moment we have no explanation for this stimulatory effect of SJAMP that anyhow in practice is entirely observed by the antithrombin effect.

The thrombin generation in platelet rich plasma after triggering the coagulation with a trace amount of thromboplastin has been considered to be due to the cooperative effect of thromboplastin and platelets. obviously, this experimental system has a closer resemblance to in vivo situations than the "classical" in vitro coagulation systems. At sufficlently high concentrations of SJAMP both a reduction of the maximal amount of thrombin formed and an Increase in the lag time of the thrombin generation process were observed. Fron these results we concluded that, in contrast to the Inhibitory effect of heparin, the inhibitory effect of SJAMP on thrombin activity is not adequately neutrallzed by platelet factor 4 released from activated platelets during the hemostatic process (18). Previous studies showed that SJAMP has the ab111ty to induce platelet aggregation (16). A small stimulatory effect of thrombin generation seen low concentrations of SJAMP may be connected with this effect of SJAMP on platelet aggregatLon. We conclude that the inhibition of thrombin activity by SJAMP 18 the predominant phenomenon in platelet rich plasma also.

The enhancing effect of heparin and 1 ts anslogues on the lahibition of coagulation serine proteases by plasma Inhibitors has been shown to depend 
Largely on the ability of these compounds to bind to the heparid cofactors, antithrowin III and heparin cofactor II (19-22). The heparin dependent lahibltion of thrombin by antithrombin III is presumably by far the most important nechanism of 1 ts anticoagulant effect (19-24). The possibility that part of the Inhibitory effect of heparin on coagulation is not mediated by antithrombin III was reported in the literatures $(25,26)$. Previlous studies sugested that SJAMP acts as an anticoagulant by inactivation of thrombln but that this lnactivation 1 s not dependent on the antithronibin III (16). Our studies presented In chapter IV are not in agreement wh these litereture findlings, however.

In chapter $\nabla$ of this thesis, a study of the antithrombin III dependency of thrombin Inhibition by SJAMP was described. We found that, in a purifled system and in an inhibitor-depleted plasma system (the euglobulin fraction), inhibition of thrombin activity by SJAMP could only be observed after reconstitution of these systems with purified human antithrombin IIT. A subsequent study carried out in antithrombin III-depleted plasm Indicate that about $20 \%$ of the SJAMP-medllated thrombin Inhibition was Independent of antithrombin III. This polnts to the involvement of other plasma inbibitor in the SJAMP-mediated inblbition, probably heparin cotactor II.

Direct blading studles based on the change in intrinsic fluorescence of antithrombin III upon interaction with SJAMP Indicated that SJAMP has only a low fifity for antithrombin III; this accounts partly for its relative Ineffectiveness as compared to standard heparin on a weight basis. The discrepancy between the SJAMP/antithrombin III binding strength and the anticoagulant activity of SJAMP may also be caused by an interaction of SJAMp wth other Inhibitors present in plasma. We conclude that SJAMP exerte 1 inhlbitory effect malnly in the antithrombin III-mediated pathway. However, the contribution of other plasma inhibitors such as heparin co-factor II to the thrombin Inhibition by SJAMP can not be neglected. 


\section{REFERBNCBS}

1. B1ggs, R., Nosse1, H.L. (1961). Thromb. Dlath. Haemorrh, 6, 1-4

2. Josso, F., Prou-Wartelle, 0. (1965). Thromb. Diath. Haemorrh. 17, 35-44

3. Osterud, B., Rapaport, S.I. (1977). Proc. Nat1. Acad. Sc1. USA. 74, $5260-5264$

4. Jesty, J., S11verberg, S.A. (1979). J. B101. Chem. 254, 12337-12345

5. Zur, M., Nemerson, Y. (1980). J. Blol. Chem. 255, 5703-5707

6. Morrison, S.A., Jesty, J. (1984). Blood. 63, 1338-1347

7. Stenf10, J., Fernlund, P., Egan, W., Roepstorff, P. (1974). Proc. Nat1. Acad. Sc1. USA. 71, 2730-2733

8. Henker, H.C., Veltkamp, J.J., Rensen, A., Loeliger, B.A. (1963). Nature (London) 200, 589

9. Josso, F., Lavergn, J.M., Gouant, 0., Prou-Warte11e, 0, soul1er, J.P. (1968). Thromb. Dlath. Haemorrh. 20,88

10. Hemker, H.C., Muller, A.D. (1968). Thromb. Dlath, Haenorrh. 20, 77-87

11. Esmon, C.T., Sutt1e, J.H., Jackson, C.M. (1975), J. Blol., Chem. 4095-4099

12. Hemker, H.C., Hamulyak, R., BEguln, S. (1986). In: Antlcoagulant Therapy. 13-23, Eds: 〈Boche〉, Basle, Swlterland.

13. Choay, J., Pet1tou, M., Lormeau, J.C., S1nay, P., Casu, B.J., Gatt1, G. (1983). Blochem. Blophys. Res. Comm. 116, 493-499

14. Fareed, J., Walenga, J.M., W11llamson, K., Bmanuele, R.M., Kumar, A., Hoppensteadt, D.A. (1985). Thromb. Haemostas. 11, 56-74

15. Koller, M., Schock, J., Buchmann, P., Larglader, F." Pelton von, A., Frlek, P,G, (1986). Thromb. Haemostas. 56, 243-246

16. LI, J.Z., Bao, C.X., Chen, G.Z., Zhag, G.Z (1985). China. Acta. Pharaacologlca. S1nica, 6, 107-110

17. Beguin, S. In: Thrombinoscopy. Thes18 (1987), Maastricht. P. 53-84

18. Lane, D.A., Dention, J., F1Yan, A.M. (1984). Blochem. J. 21,725-732

19. Rosenberg, R.D., Lam, L. (1979). Proc. Nat1. Acad. Sc1. 76, 1218-1222

20. Marton, R.B., Thomas, D.P., Havercroft, S.J., Barrowellffe, T.W., Lindah1, 0. (1984). Thromb. Haemostas. (Stuttg.) 51, 254-256

21. Tollefsen, D.M. (1984). Nouv. Rev. Fr. Hemato1. 26, 233-237

22. Ofosu, F.A., Mod1, G., Cerskus, A.L., Hilrah, J., Blajchman, M.A „ (1982) Thromb. Res. 28, 487-497 
23. Ofosu, F.A., Mod1, G.J., Hirsh, J., Buchanan, M. R.T., Blajchman, M.A. (1986). Anm. NH. Acad. Sel. 485, 41-55

24. Jordan, R.E., Dostra, G.M., Gardner, W.T., Rosenberg, R.D. (1980).

J. B1oll. Chem. 255, 10073-10080

25. Ofogu, P.A., Blajehman, M.A., H1rsh, J. (1984). Thromb. Res. 34, 125-133

26. Salzman, Z.W., Rosenberg, R.D., Smith, M.H., LInden, J.N. (1986). J. Glfn. Invest. $65,64-73$
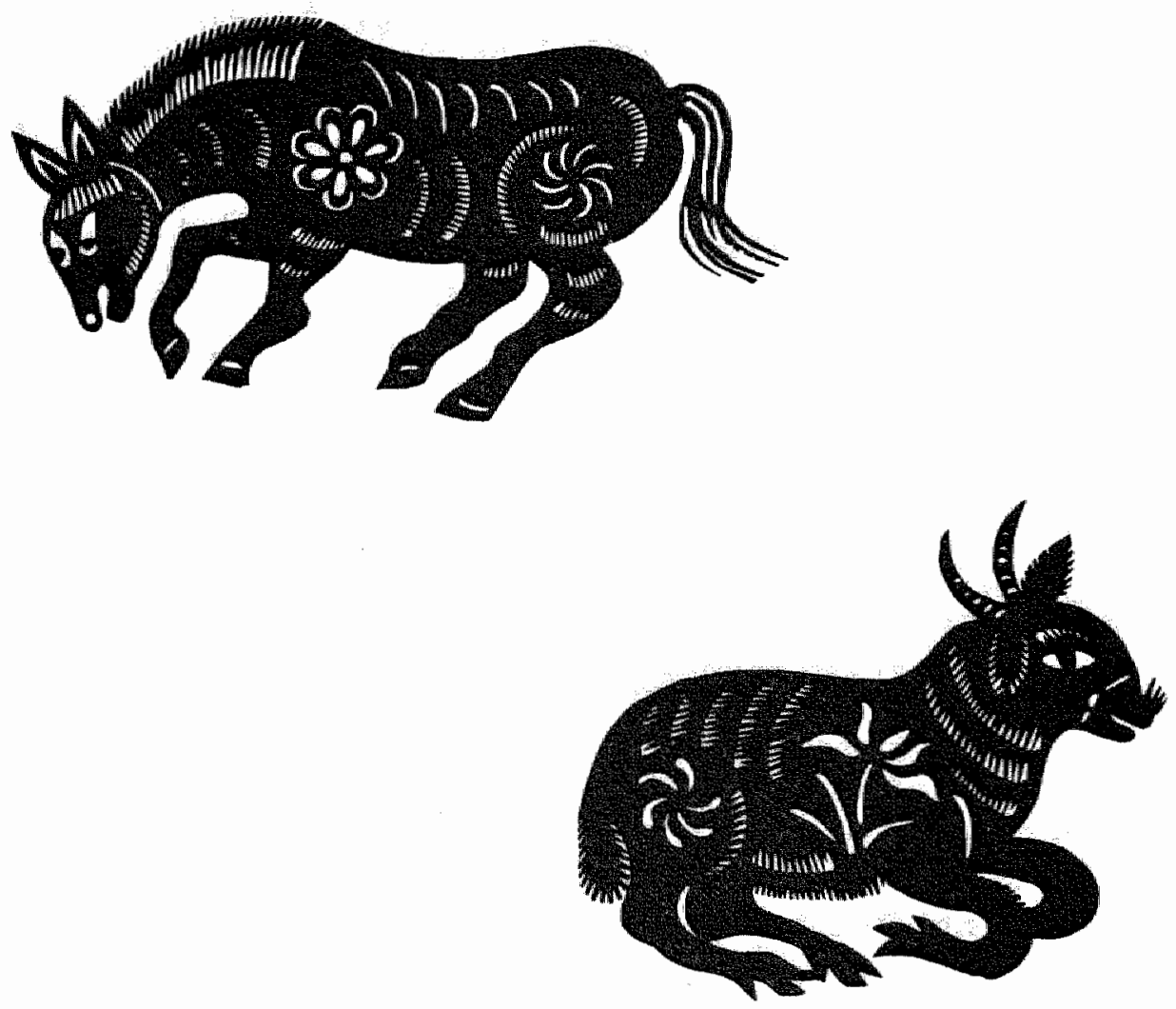
一般性讨论

本文的目的是从事血液㠜固领域中的生物化学研究; 所浩及的题目直接关系到临床医学

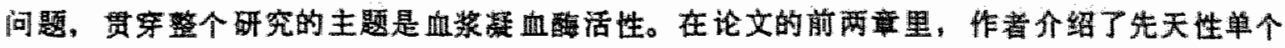

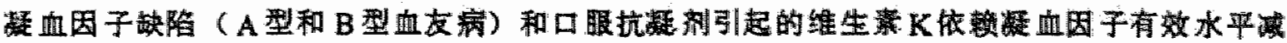

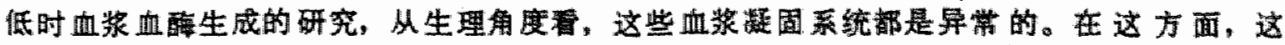

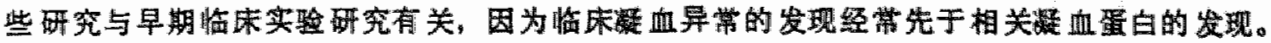

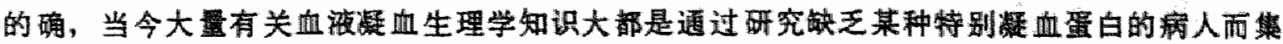

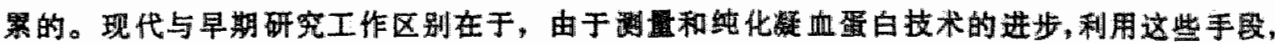
现在可以探索那些早期研究者无法涉及的问题。在论文的后两噇里, 作者介绍了S J A M P

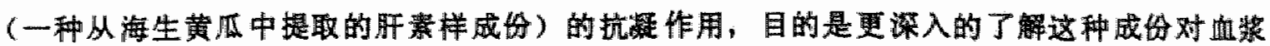
凝血酶活性的抑制。

自从 Biggs 和 Nossel 发现, 当用稀独的㠜血活酶螌发血浆烧固时, 血友病血浆不能生成

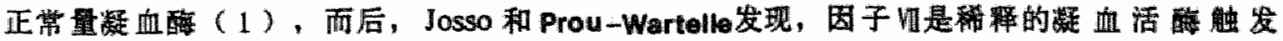
血浆凝固时血友病血浆促凝活性的基础（2），从而揕示了经典的内源和外源凝血途径的内 在联系, 但是这种联系仍不能认识。在过去十年里, 由于血液㠜固生物化学的巨大发展, 现 在可以从血浆中分离和提纯所有已知的数血蛋白并且可以把它们部分重组成血浆凝固系统。 基于这种方法，Z sterud 和 Rappaport 在部分纯化的实验体系中证实，因子切和凝血活酶 的反应产物可以激活因子 I $(3)$ ，但这条凝血途经的生理意义仍处于探讨阶段。近年来的体

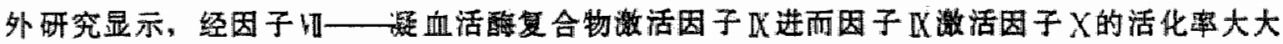

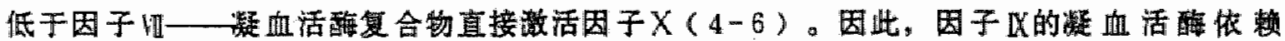
活化途经在体内㠜血的重要性难以被接受。

在论文的第二章里，作者介绍了因子【和因子䧃对外源凝血过程中凝血酶生成的贡神。 结果显示. 当用于正常外实验的疑血活酶触发血浆凝固时，因子 $\mathbb{X}$ 缺陷血浆和用纯化因子 $\mathbb{X}$

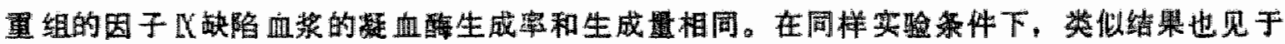

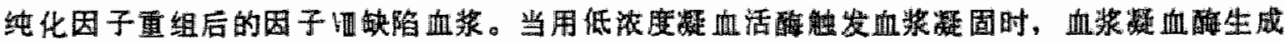

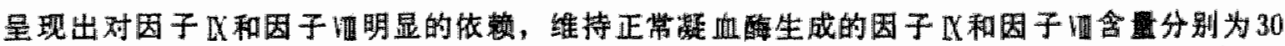

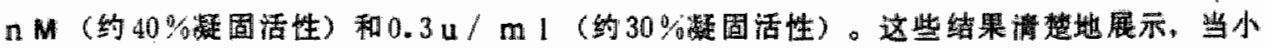

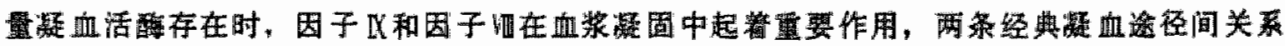
的建立, 可以适当地解释。为什么血友病内源㠜血途祬方面的异常不能的被其完整的外源凝 血途钫补裳。

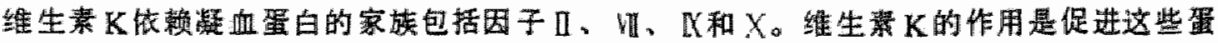

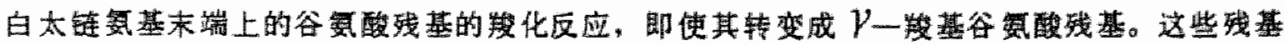

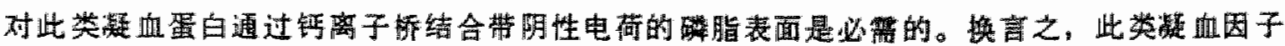

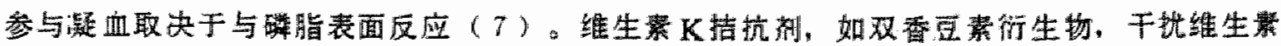

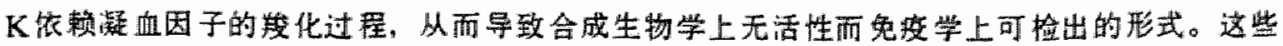




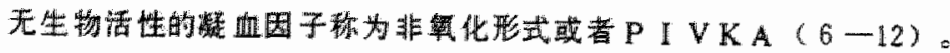

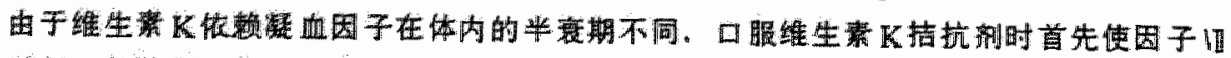

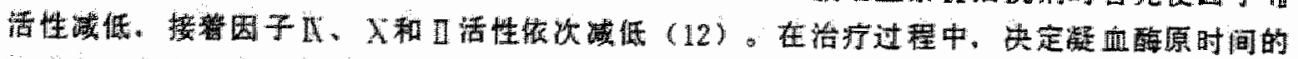

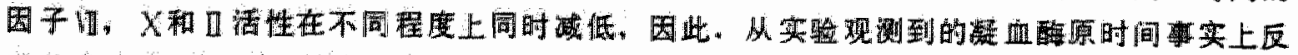

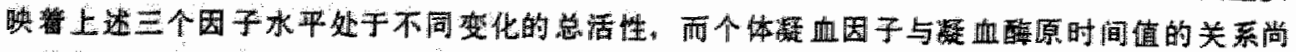

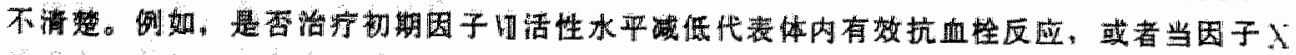

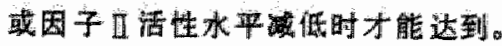

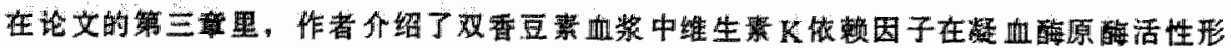

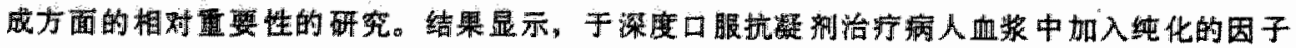

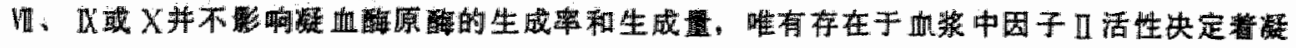

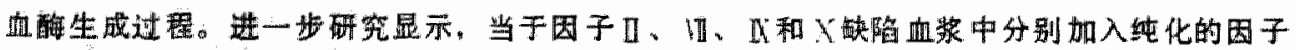
II、V、 X

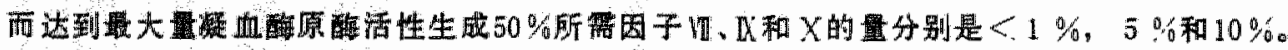

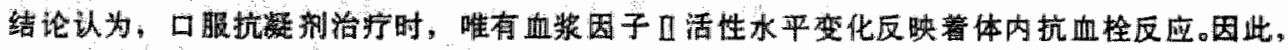

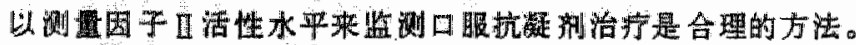

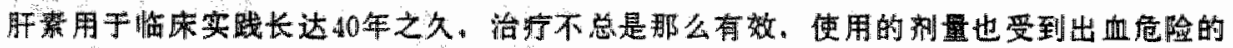

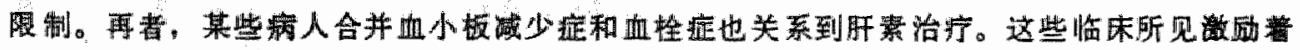

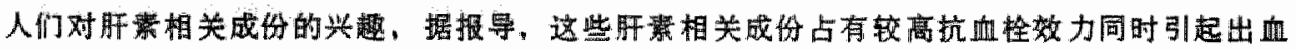

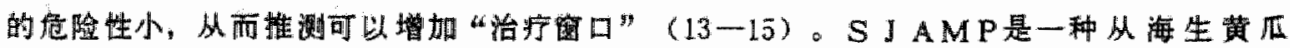

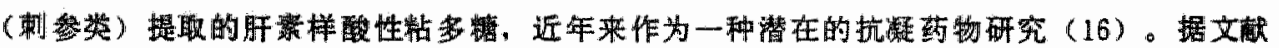

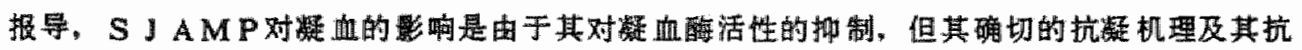

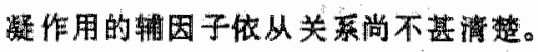

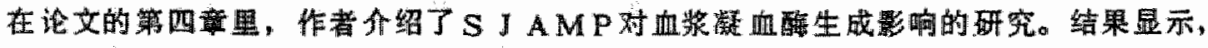

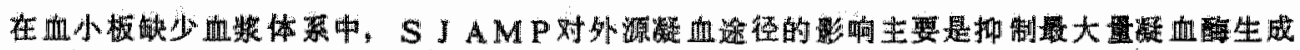

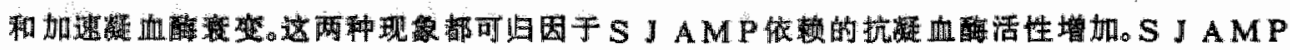

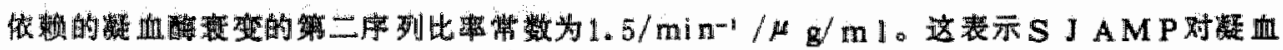

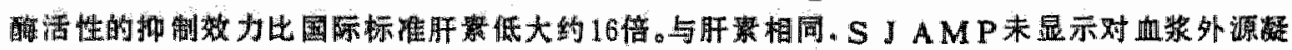

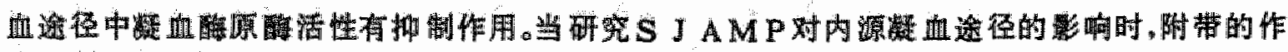

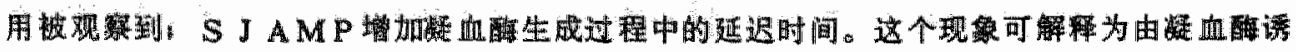

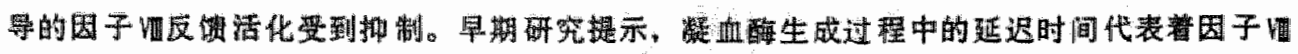

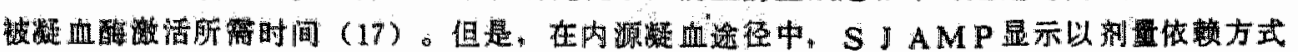

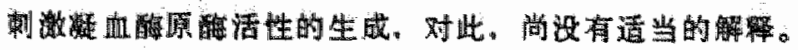

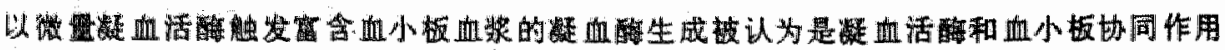

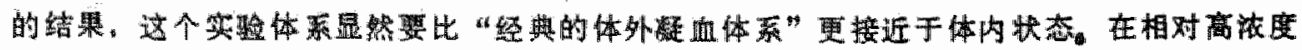

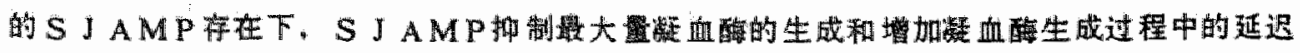


时间。结果提示, 与肝素相反 (18)。S J A M P 对凝血酶的抑制作用不易被血小板因子 4

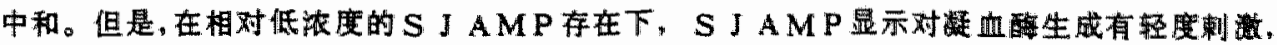
这种效应可能与 S J A M P 诱导血小板聚焦作用有关（16）。结论认为，在富含血小板血浆 中， S J A M P 的主要作用也是对凝血酶生成的抑制。

肝素及其同系物提高血浆抑制剂对凝血丝酸蛋白水解酶的作用，在很大程度上取决于

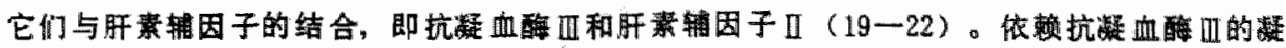

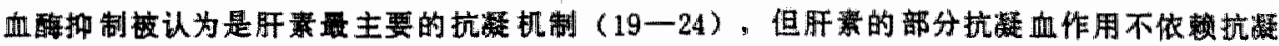

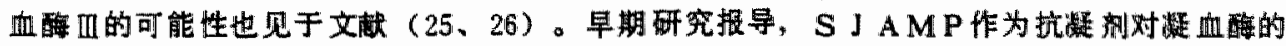
灭活不㳖抗接 血 (16)。

在论文的第五章里，作者介绍了S J A M P 对辉血酶抑制作用的辅因子怅从关系的研究。 结果显示，在纯化的体系和抑制剂去除的血将体系 (优球蛋白成分) 中，S J A MP 对数血

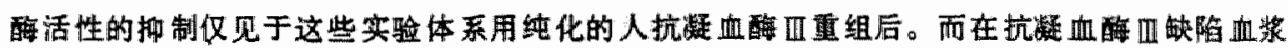
体系中的进一步研究显示, 大约 $20 \%$ 由 S J A M P 导令的凝血酶抑制不依赖于抗疑血酶四。 从面提示，在 S J A M P 导介的凝血酶抑制中有其它血浆抑制剂参与，可能是肝素辅因子】。

基于抗疑血砤 III S S A A P 反应后内源䓬光变化的直接结合实验研究提示，S J A M

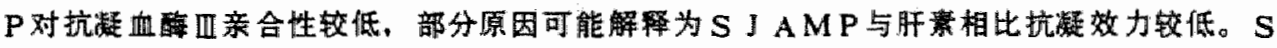

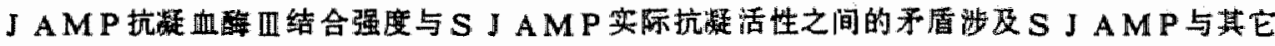

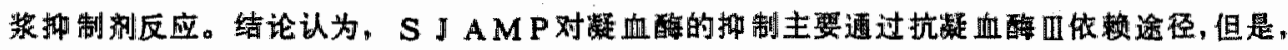

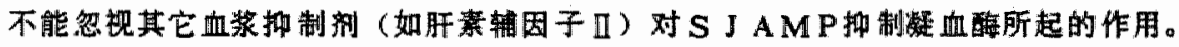




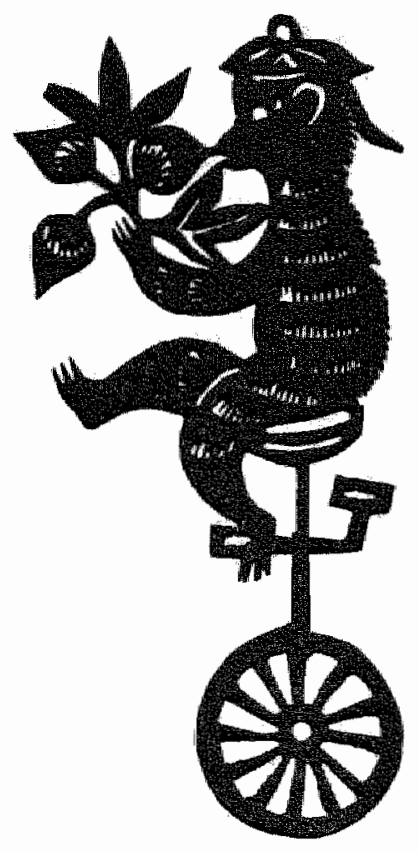


SUMAARY

The central theme tn this thesis is the generation and inhibition of thrombin 1n plasma. The first part of the thesis presents our studies on thrombin generation in plama of patlents wh congenital clotting factor deficlencles and of patients wh an acquired reduction in the affective activity of the vitamin $R$-dependent clotting factors brought about by oral administation of vitamin $K$ antagonists. The second part presents our studies on the influeace of a heparin-like material isolated from stichopus japonicus selenka (a sea cucumber) on thrombin inhibition in plasma.

Chapter I gives a general introduction in the topics that will be discusged in more detall in the following chapters.

In chapter II the importance of factor IX activation during thromboplastin-dependent coagulation in plasma (The Jasso Pathway) and thus the question "Why do haemophiliacs bleed" Is investigated. Al though numerous studies have postulated that the factor IX activation in thromboplaotindependent coagulation In plasma is of physlological Importance, attention was mostly focussed on factor $X$ activation. Convincing evidence on the generation of thrombin activity via thromboplastin-1nduced factor IX activation is lacking, however. Therefore, experiment were carried out in plasma of patients lth a congenital deflciency of the clotting factors $\mathrm{IX}$ and VIII before and after reconstitution of the plasma with purifled factor IX and VIII. The generation of thrombin activity in these systems measured after triggering coagulation th dlluted, $\mathrm{CACl}_{2}$-contalning thromboplastin solutions. It 1s shown that in factor IX defictent plasma the generation of thrombla activity is independent of the amount of factor IX present then the plasma comgulation is triggered wth the thromboplastin concentration normally used in routine tests. When, however, plasma coagulation is triggered th low concentrations of thromboplastin, a clear dependency of the generation of thrombin activity on the concentration of factor IX becomes evldent at factor IX concentrations lower than 30 nM (about 40\% cloteing factor activity). Factor VIII seemb to be a compulsory cofactor for factor IX activity, because the generation of thrombin 
activity at optinal factor IX concentration 1 sill dependent upon the amount of factor VIII present. This factor IX dependency of thromboplastin dependent coagulation probably explatns wy haewophlliacs bleed.

Chapter IIT deals th thrombin generation in dicoumarol plasma. The hypocoagulability of dicounarol plasw is due to the combined dintution of the effectue activity of the vitamin $\mathrm{K}$-dependeat clotting factors brought about by oral administration of comarlin congener. The relative contribut1on of the Individual wtamin R-dependent clotting factors to this hypocoagulability of plasma 1 a not yet clearly understood, however. The studies presented show that addition of purffled factors WII, IX or $\mathrm{X}$ to plasma from deeply anticoagulated patlents does not influence the prothrombinase formation and the amount of thrombin formed. Only the prothrombin level in dLoumarol plaswa determines the course of thrombin generation. Subsequent experiments, In which increasing amounts of the purified factors II, VII, IX or $X$ are added to plaema deflclent In respectively the factors II, VII, $I X$ or $X$, show that the prothromblaase activity 1lnearily lacreases with the concentration of factor II and that the concentration below which the factors VII, IX and $X$ start to have an apreclable effect on prothrombinase actirity are $5 \%, 20 \%$ and $40 \%$, respectively. The half maximal amount of prothromblase activity is found at about $1 \%$ for factor VII, 5\% for factor IX and $10 \%$ for factor $X$. From this study it can be concluded that in dicoumarol plasma only the changes in the prothromibin level determine the antithrombotic effect. Therefore, it seems loglcal that, for the control of oral antlcoagulant therapy, tests that reflect the prothrombla activity would be suble.

In chapter IV the antlcoagulant effect of stichopus japonicus actd mucopolysaccharlde (S.JAP), a heparin-11ke matertal laolated from the sea cucumber stichopus Japontous selenka, da descrlbed. SJAMP has recently been studied a potentil anticosgulant drug. The effect of SJAMP on blood coagulation ha been reported to be due to inhibition of thrombin activity, but the preclse mechanism of 1 to anticoagulant activity and its cofactor dependency were nothyet known. The studies presented show that the eain effect of SJAM la the inhibltion of thrombin activity in both platelet poor and platelet rich plasmas. On a relght basis the effect of sJAMP towards thrombla la about sixteen-fold weaker thap that of the 4 th International standard heparin. When experiment are carried out in 
platelet poor plasm after triggering coagulation wth thronboplastin, SJAMP Induces both a reduction of the maximal amount of thrombin formed and an acceleration of thrombin decay. An additional effect of SJAMP $1 \mathrm{~g}$ observed when coagulation in platelet poor plaswa ls triggered with Cephaloplastin. In this systea SJAMP Increases the lag time in the thrombln generation process. This effect of SJAMP can be explained by an Inhibition of the feedback activation of factor VIII by thrombin. When the effect of SJAMP is studied in platelet rich plasma after triggering coagulation with trace amounts of thromboplastin a sight gtimulation of the thrombin generation 18 observed at a low SJAMP concentration while at higher SJAMP concentrations a reduction of the maximal amount of thrombin formed and an increase in the lag time of the thrombin generation process are observed. This indicates that the Inhibitory effect of SJAMP on thrombin activity, unlike that of heparin, can not be neutrallzed by platelet factor 4 released frow activated platelets. Also in this experfmental system the Increase in the lag time of the thrombln generation process may be explained by an inhibition of the feedback activation of factor VIII and of the thromin-induced platelet stimulation.

Chapter $V$ describes the cofactor dependency of SJAMP. The enhancing effect of heparin and Its analogues on the inhibition of the coagulation serine proteases by plaswa inhibitors has been shown to depend largely on the ability of these compounds to bind to the heparin cofactors, 1 ,e. antithrombin III and heparin cofactor II. Similarly, the studies presented in this chapter show that in a purdfled systew as an an inhibitor-depleted plasma (euglobul1n fraction) the thrombin inhlbition by SJAMP is dependent upon the presence of antithrombln III. When, however, the effect of SJAMP on thrombin lahibition is tudied in an antithrombin III-depleted plaswa, it 1 s ghown that in the absence of antithrombin III the thrombin lahibition is about $20 \%$ of that found after reconstitutiom of the plasma with purified antithrombin III. This polats to the Involvement of other plasma cofactors in the SJAMPmediated thrombin Inhibition.

Direct binding studies, based on the change in the intringle fluorescence of antithrombin III upon Interaction wth SJAMP, Indicate that SJAMP has a relatively low affintty for antithrombin III; this low affinity 10 not reflected in its anticoagulant efflctency, however. The discrepancy between the SJAMP-antithrombin III binding and the anticoagulant efficlency 
of SJAMP way be caused by the Interaction of SJAMP factors such as heparin cofactor II.

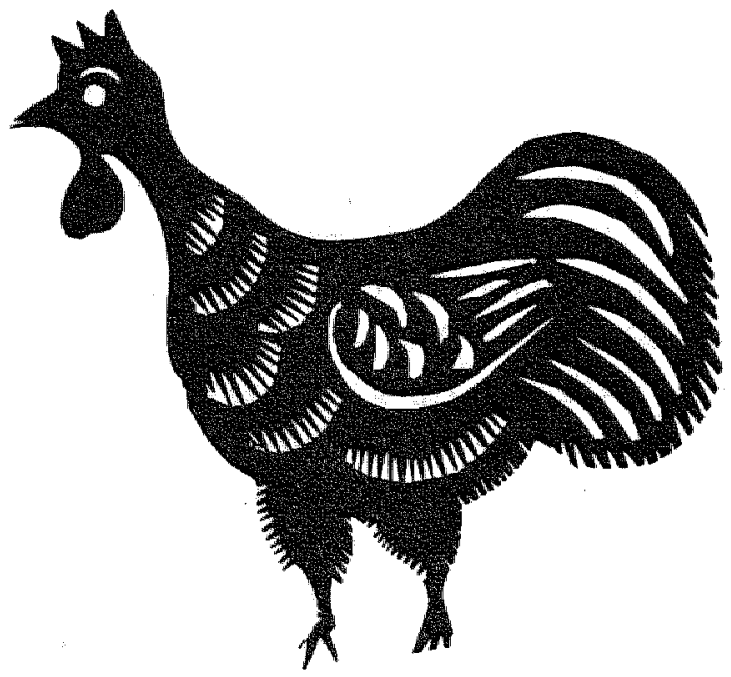


SAMENVATTING

Het centrale thema in dit proefschrift is de vorming en reming van thromblne in plasma. Het eerste deel beschriffe ons onderzoek naar de thromblne generatie in plaswa's van patienten wet congenitale stollingsfaktor deficienties en van patienten met een verkregen reduktle in de effektive aktiviteit van vitamine $K$ afhankelijke stollingsfaktoren ten gevolge van orale toedlening van vitamine $\mathrm{K}$ antagonisten. Het tweede deel beschrifft ons onderzoek maar de thromblne reaming door een heparineachtig product geisoleerd uft stichopus japonicus selenka (een zeekomkomer).

In hoofdstuk I wordt een algemene Inleidling gegeven op de onderwerpen die In de volgende hoofdstukken meer In detall zullen worden bediscusbieerd.

In hoofdstuk II wordt het belang van faktor IX aktivatle in thromboplastine-afhankel1jke stolling in plasma (de Josso pathway) en dus de wraag "Waarom bloeden haemoflelen?" onderzocht. In vele onderzoekingen lo gepostuleerd dat faktor IX aktivatle In de thromboplastine afhankelifke stolling in plasma fyslologlsch belangrijk lis mar de aandacht was hierbij voornamelijk gericht op faktor $X$ aktivatle In gezulverde systemen; een duldelijk bewljs voor de generatie van thrombine aktiviteit via thromboplastine gelnduceerde faktor IX aktivatie In plasma 18 nog nlet beschreven. Daarom werden experimenten opgezet in plasma's van patienten met congenitale defictenties van de stolliagsaktoren vili en lX voor en na reconstructie van de plasmas met de gezulverde tollingafaktoren IX an VIII. De generatie van thrombine aktiviteit in deze systemen werd gemeten na laftlatie van de stolilng net verdunde, $\mathrm{CaCl}_{2}$, bevattende, thromboplastine oplossingen. De experimenten met faktor IX deflcismt plasma laten zllen dat, als de stolling wordt gelnitleerd net de thromboplastine concentratle die wordt gebrulkt in routine tests, de generatie van de thrombine aktiviteit onafhankell jk van de hoeveelheld faktor IX 1B. Wannoer echter de stolling wordt geinftieerd met lage thromboplastine concentraties wordt, b1j faktor Ix concentratles lager dan $30 \mathrm{mM}$ (- ongeveer $40 \mathrm{x}$ stollingsfaktor aktivitelt) de generatie van de thrombine aktivitelt afhankelljk van de faktor $I X$ concentratle.

Faktor VIII 11 1kt een essentlele cofaktor voor faktor IX aktlviteit want de 
generatie van thrombine aktivitelt bil een optlwale faktor IX concentratie 1s nog oteeds afhakelljk van de aanezige hoeveelheld faktor VIII. Deze invloed van faktor IX $1 \mathrm{n}$ de thromboplastine afhankelifke stolling kan verklaren waron haenoflelen bloeden.

In hoofdstuk III wordt de thrombine generatle in het plasma van oraal geantiatolde patidnten beschreven. De hypocoagulabilitelt van dicoumarol plasma kont tot atand door een gekomblaeerde afname in de effectleve aktivltelt van de trantne $\mathrm{K}$ afhankel1Jke stollingsfaktoren onder invloed van orale antlcoagulant1. De relatleve bijdrage van de imdividuele vitanine $\mathrm{K}$ afhankel1jke stollings faktoren aan de hypocoagulabilitelt van plasma is nog niet geheel opgehelderd. Het onderzoek laat zlen dat toevoeging van de gezulverde toll1ngsfaktoren VII, IX en $X$ aan plasma van dlep geantlatolde patiênten geen lnvloed heeft op de hoeveelheld prothrombinase en de daardoor gevormde hoeveelheld thrombine; alleen de hoeveelheid prothrombine $1 \mathrm{l}$ dicoumarol plasma bepalt het verloop van de thrombine generatie. Experimenten warln toenemende hoeveelheden van de gezuiverde faktoren II, VII, IX of $X$ werden toegevoegd aan plasma"s deficlent in respectivelijk de fatoren II, VII, IX of X laten zien dat de prothrombiname aktivitelt liniale coeneemt met de faktor II concentratie en dat de concentraties waar beneden de faktoren VII, IX en $X$ een aanzlenlifke invloed op de prothromblinase aktiviteit gaan hebben respectivel1fk $5 \%, 20 z$ en $40 \% 21 \mathrm{fn}$.

De halfmaximale prothrombinase aktiviteit wordt gevonden bij ongeveer $1 \%$ faktor VII, $5 \%$ faktor $L$ en $10 \%$ faktor $X$. UIt deze studie kan worden gekonkludeerd dat alleen de verandering in de hoeveelheid prothrombino in dicomarol plagan verantwoordelijk $1 \mathrm{~g}$ voor het antithrombotisch effekt. Daarom $11 \mathrm{jkt}$ het $\log 1 \mathrm{ch}$ on woor de kontrole van orslo antistollingstheraple een teat die de prothromblne aktivitelt meet te gebruiken.

Hoofdatuk IV beschrljft de remalng van de thrombine aktivitalt onder Invloed van "Stichopus japonicus acld mucopolysaccharlde" (SJAMP) een heparineachtlg product gelsoleerd ult zeekomkommera. SJAMP 1 g recent naar voren gebracht lo een potentieel anticoagulans. Het belangrijkste effekt van SJAMP op da stolling van bloed werd hierblj gesuggeerd als een reming van de bloedplaatjes aktivitelt. Het precteze mechanlsme achter de antistollingaktivitelt de cofaktorafhanklijkheid waren echter nog niet duidel1jk. Ons onderzoek laat zlen dat het wooraaamste effekt van SJAMP, 
zowel in plaatjesarm als in platjestijk plasma, de reming van de thrombine aktivitelt is.

SJAMP heeft, berekend op een gewichtsbasis, een 16. maal geringer effekt op thrombine dan het $4 \mathrm{e}$ Internationale standaard heparine. Als de expertmenten worden ultgevoerd in plaatjesarm plasma en de tolliag wordt geInitleerd met thromboplastine geeft SJAMP zowel een reductle in de maximale hoeveelheid thrombine die wordt gevormd als een verhoging van de thrombine verdwifnsnelheld. Ben additloneel effekt van SJAMP wordt wargenomen na Inttlatie van de stolling In plastjesarm plasma met cephaloplastine. SJAMP verlengt in dit systeen de latentle-tijd in het thrombine vormings proces. DIt effekt van SJAMP kan worden verklaard ut een reming van de feedback aktivatie van faktor VIII door thrombine. Hanneer het effekt van SJAMP wordt onderzocht in plaatjesrifk plasma wordt na het indtieren van de stolling met zeer kleine hoeveelheden thromboplastine, gerlnge stimulatie van de thrombinegeneratie verkregen, terwll1 hogere SJAMP concentratles een reductie in de maximale hoeveelheld thrombine en een verlemging in de latentIe-t1jd van het thrombine generatie proces bewerkstelligen. Dit laat zlen dat het remmende effekt van SJAMP op de thrombine aktiviteit, in tegenstel11ng tot dat van heparine, niet kan worden geneutraliseerd door plaatjes faktor 4 dat vrifkomt uft geaktiveerde platjes. Ook in dit experimentele systeem kan de toename van de latentie-tijd van het thrombine generatie proces worden verklaard door een reming van de feedback aktivatie van faktor VIII en van de door thromblne geInduceerde plattes atimulatie.

Hoofdstuk $V$ beschrijft de cofaktor afhankel1jkheid van SJAMP. Het otimulerende effekt van heparine en heparineachtige stoffen op de reming van da stollings serine-proteases door plasma remmers is afhankelifk van het vermogen van deze stoffen an heparine cofaktoren zoals antithrombine III en heparine cofaktor II te binden. De resultaten in dit hoofdituk laten zien dat in gezulverde systemen ea ook in remer gedepleteerd plasma (euglobuline fraktie) de thromblne reming door SJAMP afhankelljk is van de aanwezigheld van antithrombine III. Wanneer echter het effekt wan SJAMP op de thrombime reming wordt bepaald in antithromblne III gedepleteerd planga b11jkt ongeveer $20 \%$ van de reming onafhankel $1 \mathrm{k}$ vam antithrombine III. Dit wijst op een bijdrage van andere cofaktoren dan antithrombine III aan het thrombine remende van SJAMP. 
Direkte blndtig studtes, gebaseerd op de verandertng in de Intrinsleke fluoregcentle van antithrowblne III bij Interaktie net SJAMP, laten zIen dat SJAMP een relatief lage affultelt woor antithrombine III heeft. Deze lage affintelt word echter liet weeraplegeld In de antistollings effletentle. Deze discrepantie tusgen SJAM-anththrombine III binding en de ant1stoll1ngs efflclentle van SJAMP wordeo mogel1fkerwifs veroorzalkt door de Interaktie voor SJAM wet andere elwit cofaktoren zoall heparine cofation $\mathrm{IT}$.

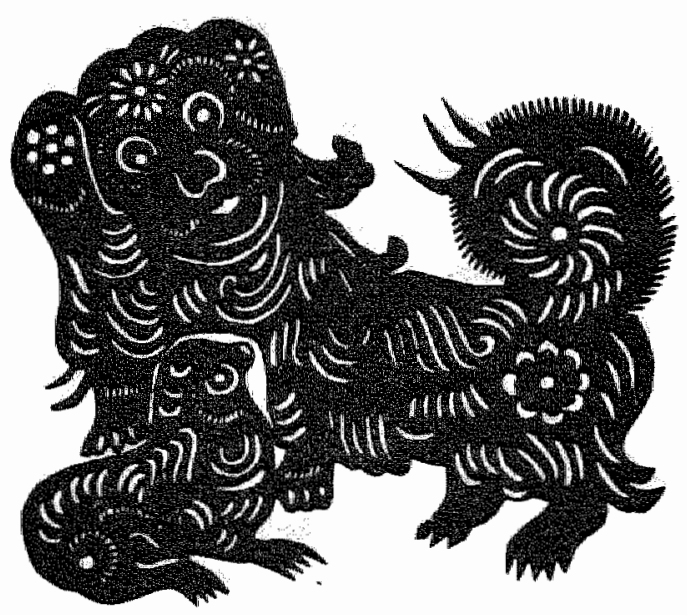


ACKNOWLEDGEMENTS

I am greatly ladebted to Prof. Dr. H.C. Hemker for Inviting me to prepare this thesis in his department and for directing this thesis. He has made great efforts with a foresight and sagaclty to establish the relation between The Netherlands and China in the fleld of hemostas and thrombosis. This work is a concrete form of this lofty ides.

I an equal1y indebted to Prof. Dr. Guy de The (President. 1'Assoclation Virus Cancer Prevention de France) for supplying me a fellowship for ay advanced study in Burope. Without his supports this thesis should not has: been possible.

My warm thanks go to Dr. Suzette Beguin and Dr. Theo Lindhout for thell datly direction of the experimente and for their close cooperation in the work of this thesis. Their profound knowledge in the fleld of blochemistry and human blology, their excellent and sophlsticated technical abllity and their persevering and open ind approach to sclentiflc research has taught me much and has largely Improved the quality of the work of this thesis.

I would like to thank especially Dr. M.C.B. van Dam-Mleras for the encouragement and help she gave me durling the time when I was struggling with my thesis. Her overwhelming energy and working efficlency substantially accelerated the work of this thesis.

I am very thankful to Paul Devilee for his friendly dally cooperation in the laboratory. He has always been wlling to help me and to share his knowledge in the fleld of blochemistry with me. His support has been invaluable in the making of this thesis.

I thank very much puck Muller for her help with the administration problems during the past years. She is very supportive colleague and friend.

I thank very much Trees Camphuisen for expert typlag this thesis. She ho always been so cooperative and patient with me. Her klndness $\mathrm{I}$ will allwa keep In nind.

I would 11ke to thank particularly Jo Pranssen, Monlca Gall1, Truve Janssen, Marlet Molenaar, Jean Pleters, Pleter Schoen and Slmone Wlelders, who have particlpated directly or Indirectly in this work.

Final1y I thank all members of the Department of Blochemistry from the University of Limburg, Maatricht, The Netherlanda, for thelr friendiy supports during my stay in Maasticht. 


$$
-108-
$$

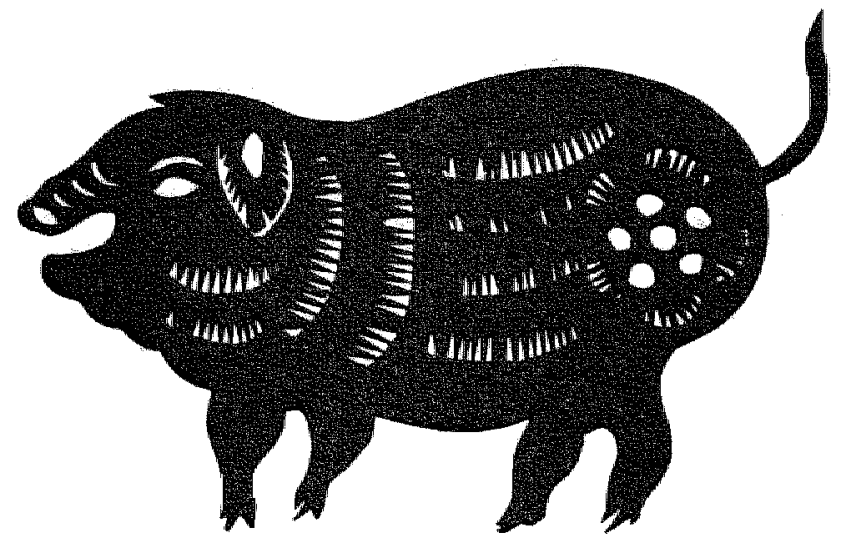




\section{CURRICULUM VITAE}

The author bora on April 13th, 1955 in Xian, the Peoples' Republic of China. After his graduation from Xlan Medical School in 1976, he followed advanced trainlag programs in the Departwent of Internal Medicine of the Children's Hosplital In Xlan, the Department of Hematology of the Medical Institute in Suzhou and the Department of Medical Blochenistry of the National Institute of Fundamental Medicine in Belfing. In September 1985, he obtalined a fellowship from 1'Association Vtrug Cancer Prevention de France (President. Prof. Dr. Guy de The) and studied in the Department of Hematology, Hopital Laribolstere, Parls (Head. Prof. Dr. J.P. Caen), where he worked under the direction of Prof. Dr. C. Sorla. In July 1986, he presented hIs "These doctorale en Hếmatolgle" at the University of Rouen (France). Since October 1986, he has been engaged as a Ph.D. student in the Department of Blochemistry, University of Llmburg, Maasticht, The Netherlands (Head. Prof. Dr. H.C. Hemker), where the work presented 1n this thesis has been carried out. 


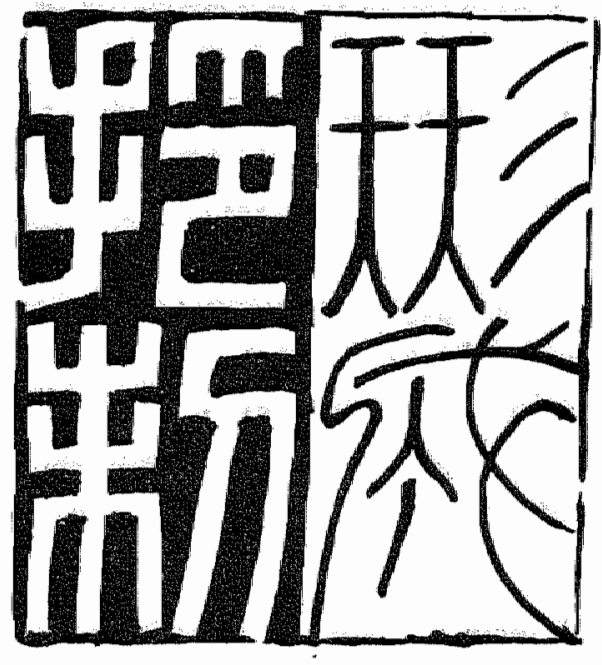

